\title{
Experimental Data Developed to Support the Selection of a Treatment Process for West Valley Alkaline Supernatant
}

\author{
L. A. Bray \\ L. K. Holton \\ T. R. Myers \\ G. M. Richardson \\ B. M. Wise
}

January 1984

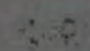

Prepared for

West Valley Nuclear Services Co., Inc.

under U.S. Department of Energy

Contract DE-AC06-76RLO 1830

Pacific Northwest Laboratory

Operated for the U.S. Department of Energy

by Battelle Memorial Institute 


\title{
DISCLAIMER
}

This report was prepared as an account of work sponsored by an agency of the United States Government. Neither the United States Government nor any agency thereof, nor any of their employees, makes any warranty, express or implied, or assumes any legal liability or responsibility for the accuracy, completeness, or usefulness of any information, apparatus, product, or process disclosed, or represents that its use would not infringe privately owned rights. Reference herein to any specific commercial product, process, or service by trade name, trademark, manufacturer, or otherwise, does not necessarily constitute or imply its endorsement, recommendation, or favoring by the United States Government or any agency thereof. The views and opinions of authors expressed herein do not necessarily state or reflect those of the United States Government or any agency thereof.

\author{
PACIFIC NORTHWEST LABORATORY \\ operated by \\ BATTELLE \\ for the \\ UNITED STATES DEPARTMENT OF ENERGY \\ under Contract DE-AC06-76RLO 1830
}

Printed in the United States of America Available from

National Technical Information Service United States Department of Commerce 5285 Port Royal Road Springfield, Virginia 22161

\begin{tabular}{lr}
\multicolumn{2}{c}{$\begin{array}{c}\text { NTIS Price Codes } \\
\text { Microfiche A01 }\end{array}$} \\
\multicolumn{2}{c}{ Printed Copy } \\
Pages & $\begin{array}{c}\text { Price } \\
\text { Codes }\end{array}$ \\
$001-025$ & A02 \\
$026-050$ & A03 \\
$051-075$ & A04 \\
$076-100$ & A05 \\
$101-125$ & A06 \\
$126-150$ & A07 \\
$151-175$ & A08 \\
$176-200$ & A09 \\
$201-225$ & A010 \\
$226-250$ & A011 \\
$251-275$ & A012 \\
$276-300$ & A013 \\
&
\end{tabular}


PNL-4969

UC-70

\section{2}

EXPERIMENTAL DATA DEVELOPED TO SUPPORT THE SELECTION OF A TREATMENT PROCESS FOR WEST VALLEY ALKALINE SUPERNATANT

L. A. Bray

L. K. Holton

T. R. Myers

G. M. Richardson

B. M. Wise

January 1984

Prepared for

West Valley Nuclear Services Co., Inc. under U.S. Department of Energy

Contract DE-AC06-76RLO 1830

Pacific Northwest Laboratory

Richland, Washington 99352 

SUMMARY AND CONCLUSIONS

At the request of West Valley Nuclear Services Co., Inc., the Pacific Northwest Laboratory (PNL) has studied alternative treatment processes for the alkaline PUREX waste presently being stored in Tank 8D2 at West Valley, New York. Five tasks were completed during FY 1983:

1. simulation and characterization of the alkaline supernatant and sludge from the tank. The radiochemical and chemical distributions between the aqueous and solid phase were determined, and the efficiency of washing sludge with water to remove ions such as $\mathrm{Na}^{+}$and $\mathrm{SO}_{4}=$ was investigated.

2. evaluation of a sodium tetraphenylboron (Na-TPB) precipitation process to recover cesium ( $\mathrm{CS}$ ) and a sodium titanate ( $\mathrm{Na}-\mathrm{TiA}$ ) sorption process to recover strontium $(\mathrm{Sr})$ and plutonium $(\mathrm{Pu})$ from the west Valley alkaline supernatant. These processes were previously developed and tested at the U.S. Department of Energy's Savannah River Plant.

3. evaluation of an organic cation-exchange resin (Duolite ${ }^{\circledR}$ CS-100) to recover Cs and Pu from the alkaline supernatant followed by an oryanic macroreticular cation exchange resin (Amberlite ${ }^{\circledR}$ IRC-718) to recover Sr.

4. evaluation of an inorganic ion exchanger (Linde Ionsiv ${ }^{\circledR}$ IE-95) to recover $\mathrm{Cs}_{S}, \mathrm{Sr}$, and $\mathrm{Pu}$ from the alkaline supernatant.

5. evaluation of Dowex ${ }^{\oplus-1, x} \times$ organic anion exchange resin to recover technetium (TC) from alkaline supernatant.

The findings of these tasks are related below.

West Valley alkaline waste was simulated to determine the distribution of key radionuclide species between the supernatant and sludge phases prior to sludye washing. Raising the $\mathrm{pH}$ of the alkaline PUREX waste from 10 to 13 decreased the solubility of Pu 100-fold; of neptunium (Np), 10-fold; and of americium (Am) and rare earths (RE), 4-fold. The solubilities of Cs, Sr, and 
Tc were not significantly affected by the change in $\mathrm{pH}$, and were about as expected at $99,0.005$, and $90 \%$ in solution, respectively.

The current process for treatment of Tank 802 sludge involves separation of the sludge and supernatant and washing of the resultant sludge to remove soluble salts. After four washes, the $\mathrm{SO}_{4}=$ level in the sludge phase was reduced to 1 wt\% equivalent of $\mathrm{Na}_{2} \mathrm{SO}_{4}$ in the waste glass (equivalent to 4 wt\% of the original $\mathrm{SO}_{4}{ }^{=}$in Tank $8 \mathrm{D2}$ ). Levels of $\mathrm{Na}^{+}$were reduced to an equivalent loading of $<7 \mathrm{wt} \% \mathrm{Na}_{2} \mathrm{O}$ in the waste glass; and 4 and $9 \mathrm{wt} \%$ of $\mathrm{Cs}$ and $\mathrm{TC}$, respectively, remained in the sludge.

The Na-TPB precipitation recovery of $C s$ from alkaline supernatant was independent of $\mathrm{pH}$ in the range of 10.4 to 12.8, and independent of temperatures in the range of 25 to $50^{\circ} \mathrm{C}$. The recovery of $\mathrm{Cs}$ was dependent on the mole ratio of $\mathrm{Na}-\mathrm{TPB} / \mathrm{CS}+K+\mathrm{Rb}$. To achieve a CS decontamination factor (DF) of $>10,000$, this ratio must be at least $1.4: 1$. The complex processing of the resulting organic precipitate, the loss of Na-TPB to the decontaminated supernatant, and the impact that this process would have on the vitrification system and the low-level waste treatment facility (LLWTF) were not addressed.

The $\mathrm{Na}-\mathrm{TiA}$ process for recovery of $\mathrm{Sr}$ and $\mathrm{Pu}$ from alkaline supernatant was enhanced at a pH of 13.7 compared to 10.4, and at a temperature of 50 compared to $25^{\circ} \mathrm{C}$. Recovery of $\mathrm{Sr}$ was independent of $\mathrm{Sr}$ concentration, indicating that the $\mathrm{Sr}$ concentration is not the controlling factor of recovery. To achieve DFs of 225 for $\mathrm{Sr}$ and $>6$ for $\mathrm{Pu}$, the weight of $\mathrm{Na}-\mathrm{TiA}$ required to process Tank $8 \mathrm{D} 2$ supernatant was estimated to be $1.2 \times 10^{5} \mathrm{~kg}$. While no adverse effects were noted when Na-TPB and Na-TiA were combined in the experiments, the precipitant chemicals should only be added to supernatant separated from the sludge.

To select ion-exchange materials for the recovery of $\mathrm{Cs}, \mathrm{Sr}, \mathrm{Pu}$, and TC from alkaline supernatant, a batch sorption screening test was completed. The results show that the organic ion-exchange resins CS-100 and IRC-718, and an inorganic ion exchanger such as IE-95, are viable candidates for the removal of $\mathrm{Cs}, \mathrm{Sr}$, and $\mathrm{Pu}$ from alkaline waste. Removal of TC using an anion resin such as Dowex-1,X8 also appears feasible. 
The removal of Cs by Duolite CS-100 was dependent upon the resin particle size, temperature, and feed $\mathrm{pH}$. Higher $\mathrm{Cs}$ loadings were achieved at smaller resin size classifications. Cesium loadings improved by a factor of 1.3 as the feed temperature was lowered from 50 to $6^{\circ} \mathrm{C}$. When the alkaline supernatant feed $\mathrm{pH}$ was increased from 10.4 to 13.6 , the cesium loading capacity at $0.5 \mathrm{C} / \mathrm{Co}_{0}$ increased by a factory of 3.3 . At a feed $\mathrm{pH}$ of 13.8 , the highest $\mathrm{Cs}$ decontamination factor achieved by the CS-100 ion-exchange resin was about 1600. No Pu decontamination was found. Elution was achieved using $0.1 \mathrm{M}$ formic acid.

Amberlite IRC-718 recovery of $\mathrm{Sr}$ was dependent upon feed $\mathrm{pH}$. Strontium DFs of 100 and 1000 were achieved after $10 \mathrm{cv}$ of feed were loaded at alkaline supernatant $\mathrm{pH}$ values of 10.8 and 13.3 , respectively. Elution was achieved using 2 M formic acid.

Linde Ionsiv IE-95 removal of radionuclides from West Valley alkaline supernatant was dependent on temperature, flow rate, Na/Cs feed ratio, and $\mathrm{pH}$. Loadings for $\mathrm{Cs}$ improved by a factor of 1.6 as the temperature was lowered from 50 to $6^{\circ} \mathrm{C}$ at $0.5 \mathrm{C} / \mathrm{Co}$. Cesium loadings increased by a factor of 1.6 as the feed $\mathrm{pH}$ decreased from 13.8 to 10.4 (the West Valley supernatant at pH 10 is more compatible with IE-95 than the SRP waste at pH 13.8). Decontamination factors of $>10^{4}$ for $\mathrm{Cs}, 10^{3}$ for $\mathrm{Sr}$, and 10 for $\mathrm{Pu}$ were achieved under the following column conditions: $0.6 \mathrm{cv} / \mathrm{h}, \mathrm{pH} 10.4,8 \mathrm{cv}$, and $25^{\circ} \mathrm{C}$. The $\mathrm{Cs}$ loading capacity on IE-95 (pH 10.4) was greater by a factor of 3.6 than on CS-100 $(\mathrm{pH} \mathrm{13.8)}$. 


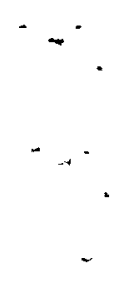




\section{CONTENTS}

SUMMARY AND CONCLUSIONS $\ldots \ldots \ldots \ldots \ldots \ldots \ldots \ldots \ldots \ldots \ldots \ldots \ldots \ldots \ldots \ldots \ldots \ldots \ldots$

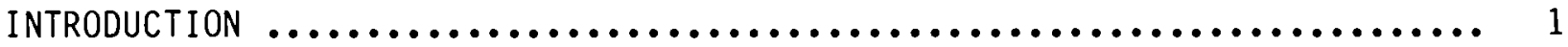

EXPERIMENTAL PROCEDURES $\ldots \ldots \ldots \ldots \ldots \ldots \ldots \ldots \ldots \ldots \ldots \ldots \ldots \ldots \ldots \ldots \ldots \ldots \ldots \ldots \ldots$

SIMULATED SUPERNATANT AND SLUDGE PREPARATION $\ldots \ldots \ldots \ldots \ldots \ldots \ldots \ldots \ldots \ldots$....... 5

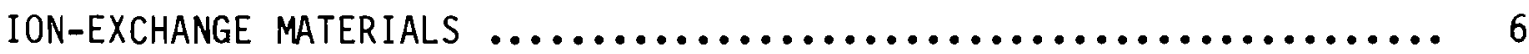

Description of Inorganic Cation Exchangers ............... 7

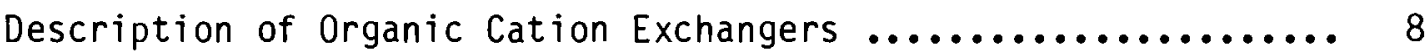

Description of Organic Anion Exchangers $\ldots \ldots \ldots \ldots \ldots \ldots \ldots \ldots$

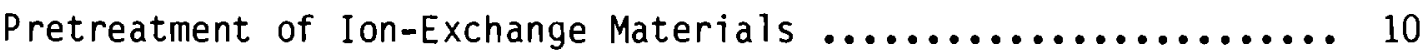

Procedures for Dynamic Ion-Exchange Loading Tests ........... 11

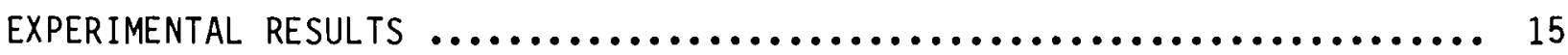

CHARACTERIZATION OF ALKALINE SUPERNATANT $\ldots \ldots \ldots \ldots \ldots \ldots \ldots \ldots \ldots \ldots . \ldots \ldots$

Feed Preparation $\ldots \ldots \ldots \ldots \ldots \ldots \ldots \ldots \ldots \ldots \ldots \ldots \ldots \ldots \ldots \ldots \ldots$

Chemical and Physical Analysis ...................... 17

Distribution of Radionuclides Between Supernatant and Sludge ... 18

LABORATORY SLUDGE WASHING STUDIES $\ldots \ldots \ldots \ldots \ldots \ldots \ldots \ldots \ldots \ldots \ldots \ldots \ldots$

Chemical Species $\ldots \ldots \ldots \ldots \ldots \ldots \ldots \ldots \ldots \ldots \ldots \ldots \ldots \ldots \ldots \ldots \ldots \ldots . . \ldots 24$

Radiochemical Species $\ldots \ldots \ldots \ldots \ldots \ldots \ldots \ldots \ldots \ldots \ldots \ldots \ldots \ldots \ldots . \ldots . \ldots . \ldots$

PRECIPITATION AND SORPTION PROCESSES $\ldots \ldots \ldots \ldots \ldots \ldots \ldots \ldots \ldots \ldots \ldots \ldots . \ldots \ldots$

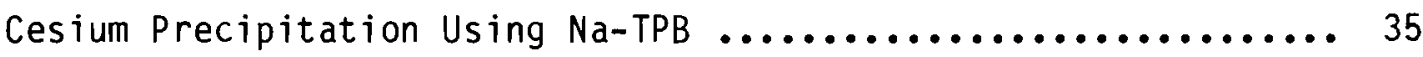

Strontium and Plutonium Adsorption Using Na-TiA ............ 39

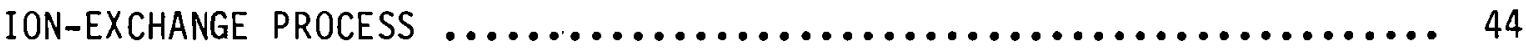

Batch Sorption $\ldots \ldots \ldots \ldots \ldots \ldots \ldots \ldots \ldots \ldots \ldots \ldots \ldots \ldots \ldots \ldots \ldots$

Organic Ion Exchange $\ldots \ldots \ldots \ldots \ldots \ldots \ldots \ldots \ldots \ldots \ldots \ldots \ldots \ldots \ldots \ldots$ 
Inorganic Ion Exchange $\ldots \ldots \ldots \ldots \ldots \ldots \ldots \ldots \ldots \ldots \ldots \ldots \ldots, 59$

Technetium Organic Anion Exchange $\ldots \ldots \ldots \ldots \ldots \ldots \ldots \ldots \ldots . . . .68$

ASSESSMENT OF ION-EXCHANGE CANDIDATES FOR CESIUM RECOVERY $\ldots \ldots \ldots \ldots 71$

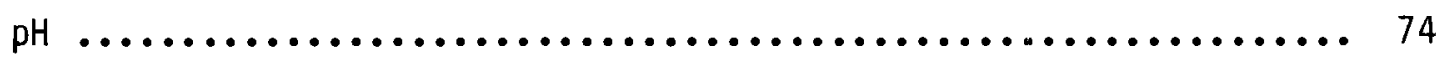

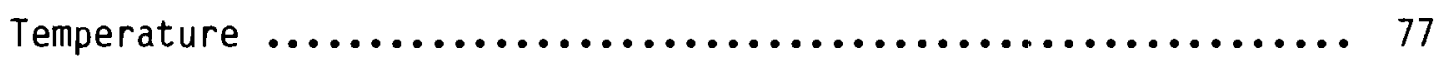

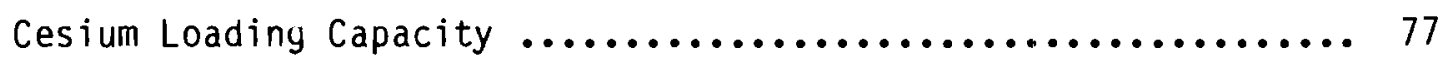

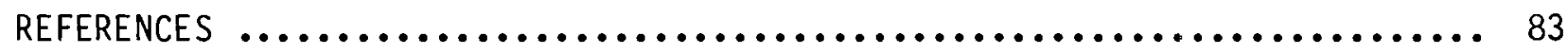

APPENDIX A - PREPARATION OF WEST VALLEY SIMULATED ALKALINE WASTE ........ A.1 APPENDIX B - WASHING PROCEDURES FOR WEST VALLEY ALKALINE WASTE SLUDGE .... B. 1 APPENDIX C - PROCEDURE TO TEST ADDITIVES THAT PRECIPITATE RADIONUCLIDES FROM ALKALINE SUPERNATANT $\ldots \ldots \ldots \ldots \ldots \ldots \ldots \ldots \ldots \ldots \ldots \ldots, \ldots \ldots \ldots$

APPENDIX D - PROCEDURE TO MEASURE BATCH SORPTION RATIOS FOR ION-EXCHANGE MATERIALS USING RADIONUCLIDE TRACER TECHNIQUES $\ldots \ldots \ldots \ldots \ldots \ldots \ldots \ldots \ldots \ldots \ldots \ldots \ldots \ldots \ldots \ldots \ldots . . \ldots \ldots \ldots$ 


\section{FIGURES}

1 Ion-Exchange Columns with a $100 \mathrm{~mL}$ Capacity $\ldots \ldots \ldots \ldots \ldots \ldots \ldots \ldots \ldots$

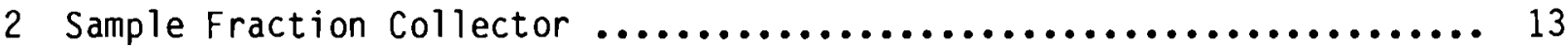

3 Settled Volume of Synthetic West Valley Sludge as a Function of

Time and $\mathrm{pH}$.......................................... 16

4 Percent of Total $\mathrm{Cs}^{+}$in Sludge as a Function of the Number of Wash Steps .......................................... 25

5 Percent of Total $\mathrm{Na}^{+}$in Sludge as a Function of the Number

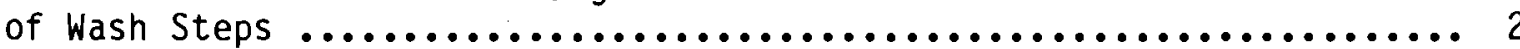

6 Percent of Total $\mathrm{NO}_{2}{ }^{-}$in Sludge as a Function of the Number of Wash Steps ......................................... 28

7 Percent of Total $\mathrm{NO}_{3}{ }^{-}$in Sludge as a Function of the Number of Wash Steps ........................................... 29

8 Percent of Total $\mathrm{SO}_{4}=$ in Sludge as a Function of the Number of Wash Steps ....................................... 30

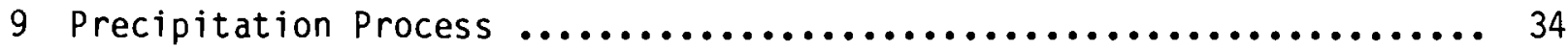

10 Cesium Precipitation from Simulated West Valley Alkaline Supernatant as a Function of $\mathrm{Na}-\mathrm{TPB} / \mathrm{CS}+\mathrm{K}+\mathrm{Rb}$ Mole Ratio, 4 M $\mathrm{Na}+\ldots \ldots \ldots \ldots \ldots . . .$.

11 Cesium Precipitation from Simulated West Valley Alkaline Supernatant as a Function of $\mathrm{Na}-\mathrm{TPB} / \mathrm{Cs}+\mathrm{K}+\mathrm{Rb}$ Mole Ratio, $7 \mathrm{M} \mathrm{Na}+\ldots \ldots \ldots \ldots . \ldots 38$

12 Adsorption of Strontium from Simulated West Valley Alkaline Supernatant Using Na-TiA ..................................

13 Adsorption of Plutonium from Simulated West Valley Alkaline

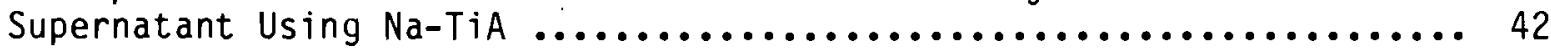

14 Organic Ion-Exchange Process $\ldots \ldots \ldots \ldots \ldots \ldots \ldots \ldots \ldots \ldots \ldots \ldots \ldots \ldots$

15 Cesium Breakthrough as a Function of Mesh Size for Organic Exchanger CS-100

16 Cesium Breakthrough as a Function of Temperature for Organic Exchanger CS-100.

17 Cesium Breakthrough as a Function of the Influent Cesium Feed Concentration for Organic Exchanger CS-100 
18 Cesium, Plutonium and Strontium Breakthrough for Organic

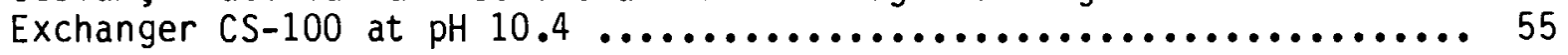

19 Cesium Breakthrough for Loading and Elution Cycle of Organic

Exchanger CS-100

20 Strontium and Plutonium Breakthrough as a Function of Column Volumes Loaded for Organic Exchanger IRC-718 at $\mathrm{pH} 10.8 \ldots \ldots \ldots \ldots \ldots \ldots \ldots \ldots$

21 Strontium and Plutonium Breakthrough for Loading and Elution Cycle of Organic Exchanger IRC-718 at $\mathrm{pH} 13.3$

22 Inorganic Ion-Exchange Process

23 Cesium in Solution as a Function of Added Powdered Zeolite

Exchanger IE-95

24 Cesium Breakthrough as a Function of Temperature for the Zeolite

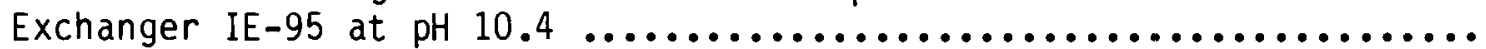

25 Cesium Breakthrough as a Function of Temperature for the Zeolite Exchanger IE-95 at $\mathrm{pH} 13.6$

26 Cesium Breakthrough as a Function of Flow Rate for Zeolite Exchanger IE-95 at $\mathrm{pH} 10.4$

27 Cesium Breakthrough as a Function of the Influent Cesium Concentration for the Zeolite Exchanger IE-95

28 Plutonium Breakthrough as a Function of Temperature for Zeolite Exchanger IE-95

29 Strontium Breakthrough as a Function of Temperature for Zeolite Exchanger IE-95 .................................... 70

30 Elution of the Zeolite Exchanger IE-95 Using $1 \mathrm{M} \mathrm{HNO}_{3} \ldots \ldots \ldots \ldots \ldots$

31 Elution of the Zeolite Exchanger IE-95 Using $4 \mathrm{M} \mathrm{HNO}_{3} \ldots \ldots \ldots \ldots \ldots$

32 Technetium Breakthrough for Organic Anion Resin Dowex-1,x8 ........ 75

33 Technetium Breakthrough for Loading and Elution Cycles of

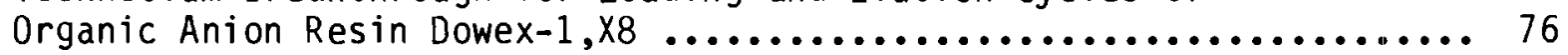

34 Cesium Breakthrough as a Function of Exchanger and Feed $\mathrm{pH}$........ 78

35 Cesium Loading Capacity as a Function of Temperature ............. 80

36 Cesium Loading Capacity as a Function of $\mathrm{Na} / \mathrm{Cs}$ Mole Ratio .......... 82 


\section{TABLES}

1 Average Composition of West Valley, Hanford, and SRP Alkaline Supernatant

2 Particle Size Distribution of Wet-Sieved Exchangers $\ldots \ldots \ldots \ldots \ldots \ldots . . .11$

3 Analysis of Synthetic Alkaline Supernatant $\ldots \ldots \ldots \ldots \ldots \ldots \ldots \ldots . . . .18$

4 Distributions and Concentrations of Radiochemical Species

in West Valley Alkaline Waste $\ldots \ldots \ldots \ldots \ldots \ldots \ldots \ldots \ldots \ldots \ldots \ldots, 20$

5 Cesium Tracer Tests in Alkaline Supernatant $\ldots . \ldots \ldots \ldots . . . \ldots \ldots . . .21$

6 Strontium Tracer Tests in Alkaline Supernatant .................. 21

7 Europium Tracer Tests in Alkaline Supernatant .................. 21

8 Technetium Tracer Tests in Alkaline Supernatant $\ldots \ldots \ldots \ldots \ldots \ldots \ldots, 22$

9 Plutonium Tracer Tests in Alkaline Supernatant ................. 22

10 Neptunium Tracer Tests in Alkaline Supernatant $\ldots \ldots \ldots \ldots \ldots \ldots \ldots \ldots .23$

11 Americium Tracer Tests in Alkal ine Supernatant $\ldots \ldots \ldots \ldots \ldots \ldots \ldots \ldots .23$

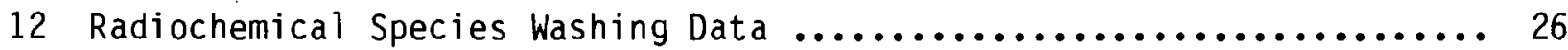

13 Percent of Total $\mathrm{Sr}$ and $\mathrm{Pu}$ in Final Washed Supernatant ............. 27

14 Chemical Species Washing Data, pH 10 ........................ 31

15 Chemical Species Washing Data, pH $10+\mathrm{Na}-\mathrm{TiA} \ldots \ldots \ldots \ldots . . \ldots \ldots . . . .631$

16 Chemical Species Washing Data, $\mathrm{pH} 13 \ldots \ldots \ldots \ldots \ldots \ldots \ldots \ldots \ldots . \ldots . \ldots . \ldots . \ldots 2$

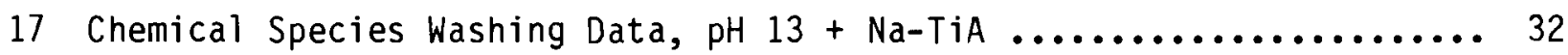

18 Precipitation of Cesium Using Na-TPB $\ldots \ldots \ldots \ldots \ldots \ldots \ldots \ldots \ldots \ldots \ldots . . \ldots \ldots$

19 Removal of Cesium from Alkaline Supernatant Using Na-TPB at

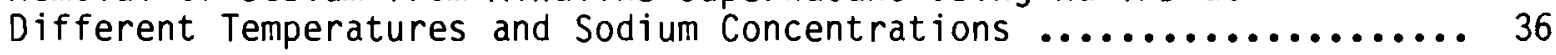

20 Removal of Strontium from Alkaline Supernatant Using Na-TiA Slurry ... 40

21 Removal of Plutonium and Strontium from Alkaline Supernatant Using $\mathrm{Na}-\mathrm{TiA}$ as a Function of $\mathrm{pH}$ and Temperature $\ldots \ldots \ldots \ldots \ldots \ldots \ldots . . . . . .43$

22 Optimum Conditions for a Precipitation System $\ldots \ldots \ldots \ldots \ldots \ldots \ldots \ldots . . . \ldots 5$ 
23 Batch $R_{d}$ Values for Radionuclides for Different Exchanger Types ..... 47

24 Cesium Loaded on CS-100 as a Function of $\mathrm{Na} / \mathrm{Cs}$ Mole Ratio .......... 54

25 Optimum Conditions for an Organic Ion-Exchange System ........... 59

26 Volumes of Feed Loaded as a Function of Temperature and $\mathrm{pH} \ldots \ldots \ldots$

27 Cesium Loaded on IE-95 as a Function of $\mathrm{Na} / \mathrm{C}$ s Mole Ratio .......... 68

28 Breakthrough Values for IE-95 as a Function of Temperature ....... 71

29 Batch Elution of IE-95 Using Nitric and Formic Acid ............ 71

30 Optimum Conditions for an Inorganic Ion-Exchange System $\ldots \ldots \ldots \ldots \ldots$

31 Cesium Loading Capacity on IE-95 and CS-100 as a Function of pH for the West Valley Synthetic Alkaline Supernatant ................. 79

32 Cesium Loading Capacity on IE-95 and CS-100 as a Function of Temperature for the West Valley Alkaline Supernatant ............. 81

34 Cesium Loading Capacity on IE-95 and CS-100 as a Function of the $\mathrm{Na} / \mathrm{Cs}$ Mole Ratio for the West Valley Alkaline Supernatant 


\section{INTRODUCTION}

Under contract to the Department of Energy (DOE), West Valley Nuclear Services Co., Inc. (WVNS) will construct and operate facilities at West Valley, New York, to solidify existing alkaline PUREX and acidic Thorex waste presently stored in underground tanks. These wastes will be solidified in a form suitable for transportation to and disposal in a federal geologic repository in compliance with the West Valley Demonstration Project (WVDP) Act of 1980 (Public Law 96-368).

The principal focus of high-level waste (HLW) solidification at west Valley will be on the alkaline PUREX waste because of its physical and chemical characteristics and its large volume $\left(2 \times 10^{6} \mathrm{~L}\right)$ when compared to the acidic Thorex waste $\left(4.5 \times 10^{4} \mathrm{~L}\right)$. Based upon an early Environmental Impact Statement (DOE/EIS-0081, US DOE 1982), a record of decision was published in the Federal Register (July 16, 1982) specifying a preferred processing approach for the West Valley wastes based upon technical, environmental, and economic considerations. The preferred approach involves separating and decontaminating the alkaline PUREX waste supernatant and combining radioactive materials recovered from the supernatant with the remaining alkaline PUREX sludge and acidic Thorex wastes. These HLW streams will be converted to a stable terminal waste form such as borosilicate glass. The decontaminated supernatant will be solidified as a low-level waste (LLW) product.

WVNS has requested assistance from Pacific Northwest Laboratory (PNL) in defining and characterizing the processes to be used for waste treatment and solidification. The purpose of this study is to provide a preliminary assessment of ion exchange and precipitation processes for decontaminating the alkaline waste supernatant and to characterize the waste in the West Valley highlevel waste tank 802 .

The technology for decontamination of alkaline PUREX supernatant has been developed and demonstrated at Hanford, Washington and the Savannah River Plant (SRP), South Carolina. The processes developed for supernatant decontamination have included inorganic ion exchange, organic ion exchange, and precipitation. Using this technology as a starting point, experimental studies were conducted 
at PNL to examine the performance of these processes using simulated West Valley alkaline wastes. These studies have narrowed the list of potential processes for use at West Valley to three, each capable of satisfying minimum technical requirements:

- an organic ion-exchange process which utilizes Duolite CS-100 resin for Cs and Pu recovery, and Amberlite IRC-718 resin for Sr recovery.

- an inorganic process which utilizes zeolite Ionsiv IE-95 ion exchanger for $\mathrm{Cs}, \mathrm{Sr}$, and $\mathrm{Pu}$ recovery. This inorganic ion exchanger can be blended with the alkaline waste sludge and converted to a glass waste form, or eluted with acid and processed as LLW.

- a precipitation process which utilizes Na-TPB to selectively precipitate cesium ( $C s)$, potassium $(K)$, and rubidium (Rb), combined with $\mathrm{Na}-\mathrm{TiA}$ for $\mathrm{Sr}$ and $\mathrm{Pu}$ recovery.

A fourth process for removal of technetium (TC) from the alkaline supernatant was also investigated. This organic anion-exchange process utilizes a quaternary ammonium polystyrene, strong-base anion exchange resin such as Dowex-1,X8 for Tc recovery. It would be used in conjunction with the first three processes for treatment of the alkaline supernatant.

Additional studies were completed to simulate and characterize the alkaline waste and sludge representing the HLW in West Valley tank 8D2. The chemical and radiochemical distribution between the sludge and supernatant was determined with and without precipitant chemicals. Sludge washing efficiencies for the principal chemical and radiochemical species were determined after batch washing of the sludge with water.

Laboratory tests were conducted to provide a technical data base for a preliminary conceptual engineering design, completed in 1983, for treatment of the West Valley alkaline supernatant. High level waste similar to that determined by the preliminary analysis of Tank 8D2 was simulated and characterized by caustic neutralization and precipitation of acidic PUREX waste. Chemical and radiochemical distributions were determined for the resulting sludge and supernatant phases. The sludge was then washed to determine the chemical and radiochemical distribution between the water and sludge. The efficiency of $\mathrm{Na}^{+}$ 
and $\mathrm{SO}_{4}=$ ion removal from the sludge by washing was investigated. A simulated alkaline supernatant was also prepared by direct chemical mixing to test proposed precipitation and ion-exchange flowsheets.

Laboratory experiments were conducted to study the performance of a precipitation process (Na-TPB) for the recovery of $\mathrm{Cs}$, and a sorption process ( $\mathrm{Na}-\mathrm{TiA})$ for the recovery of $\mathrm{Sr}$ and $\mathrm{Pu}$ from simulated alkaline supernatant. The effects of temperature, $\mathrm{pH}$, contact time, and quantity of precipitant chemicals were investigated.

The ability of organic and inorganic ion exchangers to decontaminate alkaline supernatant by removing $\mathrm{C} s, \mathrm{Sr}, \mathrm{Pu}$, and TC was evaluated. Determining batch relative distribution $\left(R_{d}\right)$ values for selected radionuclides as a function of exchanger type provided a rapid and cost-effective method for comparing a wide variety of materials for their selectivity for specific radionuclides. The batch test was used to rank the candidate exchangers and to select exchangers for further testing in flow-through columns. Column tests were then completed; and the effects of process parameters such as flow rate, $\mathrm{pH}$, and temperature on selected exchangers were examined using synthetic alkaline supernatant containing ${ }^{137} \mathrm{Cs},{ }^{85} \mathrm{Sr},{ }^{238} \mathrm{Pu},{ }^{22} \mathrm{Na}$, or ${ }^{99} \mathrm{TC}$ radionuclide tracers. Both radionuclide loading and elution tests were completed and evaluated. 
$-$

$\ldots$ 


\section{EXPERIMENTAL PROCEDURES}

Data from experiments related to the waste composition of Tank 8D2 at West Valley and a general description of ion-exchange materials tested is given in this section. For a detailed presentation of the preparation of West Valley simulated alkaline waste, sludge washing procedures, and test procedures for precipitation and batch ion exchange, see the appendixes.

SIMULATED SUPERNATANT AND SLUDGE PREPARATION

Simulated supernatant and sludge for these studies were prepared based on the West Valley waste composition outlined in a presentation by WWS personnel to Vitro Engineering, June 29, 1982 in Richland, Washington and in pertinent documents (US DOE 1978; US DOE 1982). The ions of major importance in evaluating the chemical processes include $\mathrm{Sr}^{2+}, \mathrm{Cs}^{+}, \mathrm{K}^{+}, \mathrm{Na}^{+}$and $\mathrm{OH}^{-}$. The estimated composition of the West Valley alkaline waste and average values for the Hanford and Savannah River Plants were compared to determine similarities. During the time period in which this study was completed, the contents of Tank 8D2 were analyzed further (Table 1 ).

Alkaline supernatant decontamination processes developed at Savannah River (Wallace and Ferguson 1980) and further investigated at the Westinghouse R\&D Center, Pittsburgh, Pennsylvania (Grant 1983) used alkaline supernatant with a $\mathrm{pH}$ of 13 to 14. A review of the Hanford PUREX alkaline waste (pH 10 to 11) indicated that the West Valley supernatant ( $\mathrm{Na} / \mathrm{Cs}$ mole ratio of $6500, \mathrm{pH} 10.4$ ) may more nearly resemble Hanford waste. Therefore, both $\mathrm{pH} 10$ and 13 wastes were prepared for evaluation.

Two approaches have been used to simulate alkaline wastes. In the first, the wastes were prepared by neutralization of acidic PUREX wastes, forming a sludge phase and a supernatant phase. The initial acidic wastes were adjusted to contain radionuclide tracers of interest. The resulting sludge phase was used in laboratory washing studies. The alkaline supernatant prepared by this technique was used in the supernatant characterization study. The second approach involved preparation of alkaline supernatant by direct mixing of the 
TABLE 1. Average Composition of West Valley, Hanford, and SRP Alkaline Supernatant

Concentration, $M$

\begin{tabular}{|c|c|c|c|c|c|}
\hline Ion & West valley (a) & West valley (b) & Hanford (c & SR & RP Reference ${ }^{(d)}$ \\
\hline $\mathrm{Na}^{+}$ & $6.9 E+0$ & $6.6 E+0$ & $4.6 E+0$ & $=$ & $5.8 E+0$ \\
\hline $\mathrm{Rb}^{+}$ & $1.1 E-4$ & $3.7 \mathrm{E}-4$ & -- & & -- \\
\hline $\mathrm{K}^{+}$ & $6.9 \mathrm{E}-2$ & $1.9 \mathrm{E}-1$ & $2.4 E-2$ & $=$ & $7.0 \mathrm{E}-2$ \\
\hline $\mathrm{Cs}^{+}$ & $1.1 \mathrm{E}-3$ & $1.4 \mathrm{E}-3$ & $2.0 E-4$ & $v 1$ & $1.3 E-4$ \\
\hline $\mathrm{Sr}^{++}$ & $2.6 \mathrm{E}-6$ & $8.7 E-6$ & -- & & $1.6 E-7$ \\
\hline $\mathrm{NO}_{3}^{-}$ & $4.4 E+0$ & $3.5 E+0$ & 5.8 E-1 & $\downarrow-$ & $2.2 E+0$ \\
\hline $\mathrm{NO}_{2}^{-}$ & $1.7 \mathrm{E}+0$ & $2.1 E+0$ & $2.2 E+0$ & $=$ & $1.1 E+0$ \\
\hline $\mathrm{CO}_{3}=$ & -- & $3.4 \mathrm{E}-1$ & $7.7 \mathrm{E}-1$ & +.2 & $3.0 \mathrm{E}-1$ \\
\hline $\mathrm{OH}^{-}$ & -- & $2.0 \mathrm{E}-1$ & -- & & $7.5 \mathrm{E}-1$ \\
\hline $\mathrm{SO}_{4}=$ & $3.0 \mathrm{E}-1$ & $2.5 \mathrm{E}-1$ & $1.0 \mathrm{E}-1$ &,- 2 & $3.0 \mathrm{E}-1$ \\
\hline $\mathrm{pH}$ & 9.5 to $10^{(\mathrm{e})}$ & 10 to 11 & 10 to 11 & $=$ & 13 \\
\hline
\end{tabular}

Ratios:

$\begin{array}{lllll}\mathrm{NO}_{3} / \mathrm{NO}_{2} & 2.5 \mathrm{E}+0 & 1.7 \mathrm{E}+0 & 2.6 \mathrm{E}-1-i & 2.0 \mathrm{E}+0 \\ \mathrm{Na} / \mathrm{Cs} & 6.3 \mathrm{E}+3 & 4.8 \mathrm{E}+3 & 2.3 \mathrm{E}+3+.2 & 4.4 \mathrm{E}+4 \\ \mathrm{Na} / \mathrm{K} & 1.0 \mathrm{E}+2 & 3.5 \mathrm{E}+1 & 1.9 \mathrm{E}+2= & 8.2 \mathrm{E}+1 \\ \mathrm{Na} / \mathrm{Rb} & 6.3 \mathrm{E}+4 & 1.8 \mathrm{E}+4 & -- & --\end{array}$

(a) US DOE 1978; US DOE 1982.

(b) Letter, Knabenschuh, WVNS, to Hannum, DOE, 1983.

(c) Buckingham 1967

(d) Wiley 1976a, 1976b.

(e) Based on litmus paper test on Tank 802 supernatant.

appropriate chemicals. This approach was used to prepare the feed for the batch and column ion-exchange tests. Both experimental approaches are detailed in Appendix A.

\section{ION-EXCHANGE MATERIALS}

One of the objectives of this study was to assess oryanic and inorganic ion exchange processes for decontamination of West Valley supernatant. This section provides a brief description of the selected ion exchangers, discusses 
chemical pretreatment prior to use, and describes the equipment used for column ion-exchange loading tests.

Description of Inorganic Cation Exchangers

Several naturally occurring and synthetic minerals exhibit a high cation exchange capacity and specificity for $\mathrm{Sr}$ and $\mathrm{CS}$. Among the most important members of this class are the zeolites. Zeolites are hydrated, crystalline aluminosilicates with the molecular structure $\left(\mathrm{M}, \mathrm{N}_{2}\right) \mathrm{O}^{\bullet} \mathrm{Al}_{2} \mathrm{O}_{3} \cdot \mathrm{nSiO}_{2} \cdot \mathrm{mH}_{2} \mathrm{O}$, where $\mathrm{M}$ is an alkaline earth and $N$ an alkali metal. Zeolites have a relatively open three-dimensional framework with channels and interconnecting cavities in the aluminosilicate lattice. The zeolite lattice consists of $\mathrm{SiO}_{4}$ and $\mathrm{AlO}_{4}$ tetrahedra that have their oxygen atoms in common. Since aluminum is trivalent, the lattice carries a negative electric charge (one elementary charge per aluminum atom). This charge is balanced by alkali or alkaline earth cations, which do not occupy fixed positions but are free to move in the channels of the lattice framework. These ions act as counter ions and can be replaced by other cations. Specificity and exchange capacity are determined by the $\mathrm{SiO}_{2} / \mathrm{Al}_{2} \mathrm{O}_{3}$ ratio and the crystalline structure. Ion exchange capacity is increased by the lower silica/alumina ratios, and greater acid stability from the higher ratios (Swift 1962; Buckingham 1967).

Synthetic zeolites are prepared by gelling sodium silicate, sodium aluminate, and sodium hydroxide in fixed ratios followed by digestion to permit crystallization to a particle size of 0.1 to 10 microns. The zeolite crystals are then mixed with a clay binder, extruded, dried, and rotary-kiln fired at about $1200^{\circ} \mathrm{F}$. The synthetic zeolites have been most widely used as "molecular sieves" which, because of their very small and uniform pore structure, can sorb small molecules but completely exclude molecules larger than the pore openings. Typical pore openings range from 3 to $13 \AA$, depending on the zeolite type (Buckingham 1967).

Linde Ionsiv IE-95, AW-500 and A-51 are synthetic zeolites produced by the Union Carbide Corporation. IE-95 and AW-500 are alkali metal aluminosilicates primarily of the chabazite structure in the mixed ionic $\left(\mathrm{Na}^{+}, \mathrm{Mg}^{2+}, \mathrm{Ca}^{2+}\right)$ form. The A-51 ion exchanger is an alkali metal aluminosilicate of the Type $A$ 
crystal structure supplied in the $\mathrm{Na}^{+}$form. Inorganic zeolite ion exchangers have been used in large-scale nuclear operations. Some of these are summarized below:

- recovery of CS from alkaline supernatant at the Hanford plant (Nelson and Mercer 1963; Bray and Van Tuyl 1961).

- cesium recovery in high-alkaline supernatants during use at Hanford--DFs of $10^{4}$ were demonstrated (Buckingham 1967).

- cleanup of $\sim 700,000$ gallons of reactor containment water at Three Mile Island--DFs of $10^{9}$ for ${ }^{137} \mathrm{Cs}$ and ${ }^{90} \mathrm{Sr}$ were achieved (Hitz et al. 1982; Barletta and Swyler 1983).

Description of Organic Cation Exchangers

Savannah River Laboratories has studied both inorganic and organic exchangers for cesium recovery (Wallace and Wiley 1975). Duolite C-3 and its analytical grade ARC-359, both produced by Diamond Shamrock Corporation, are examples of granular strong-acid cation exchangers of the phenol-formaldehyde type of sulfonic and phenolic exchange sites.

Duolite CS-100 is a granular phenol-formaldehyde condensation polymer with carboxylic acid functional groups. It has been demonstrated to be highly selective for Cs in highly alkaline systems such as those characteristic of SRP alkaline supernatant ( $\mathrm{pH}$ 13.8). The presence of the phenolic hydroxyl group provides the selectivity of this resin for $\mathrm{Cs}$ in competition with $\mathrm{Na}$. This very weakly acidic group is activated at $\mathrm{pH}$ values above 9. CS-100 was chosen for future development because of its excellent performance with SRP wastes. Summarized below are the principal factors which led to the selection of CS-100:

- It has a high loading capacity (E. I. du Pont 1980).

- Its breakthrough capacity (expressed as $L$ feed/L resin) is very good as a result of its loading capacity and excellent kinetics (E. I. du Pont 1980; Wallace 1980).

- Elution studies indicate that Cs elutes very efficiently from CS-100. 
- CS-100 is best eluted (E. I. du Pont 1980,1981 ) by formic acid, which can be processed easily in the solidification facility.

- CS-100 sorbs an appreciable amount of Sr, though not enough to eliminate the need for a Sr selective resin (E. I. du Pont 1981; Wallace and Ferguson 1980).

- Experimental work with CS-100 using simulated alkaline supernatant has shown that DFs of $10^{5}$ for Cs are possible (Baumgarten et al. 1980).

- Plutonium DFs are expected to be in the range of 100 to 200 (E. I. du Pont 1981; Chandler 1981).

- CS-100 is expected to have very good radiation stability due to its aromatic polycondensation structure (Gangwer, Goldstein, and Pillay 1978).

Amberlite IRC-50, -84 , and -718 spherical organic cation resins, manufactured by Rohm and Haas Company, are examples of macroporous cation exchange resins with varying properties and selectivities. IRC-50 and -84 contain slightly ionized carboxylic acid groups and can be regenerated easily with weak acids such as formic acid. Amberlite IRC-718 is a crosslinked macroreticular chelating cation exchanger with a particular selectivity for the heavy metal cations. Summarized below are the factors which led to the selection of IRC-718:

- IRC-718 elutes effectively with $\mathrm{HCOOH}$ and is regenerated with $\mathrm{NaOH}$ (Baumgarten et al. 1980; Wallace and Ferguson 1980).

- Sr distribution coefficients are generally a factor of 10 higher than those of competing ions on IRC-718 (3000 versus 300), even in the presence of carbonate and sulfate anions (Baumgarten et al. $1980)$.

- IRC-718 swells only 50\% upon regeneration (Baumgarten et al. 1980).

- Radiation stability of IRC-718 is expected to be good due to its polystyrene divinylbenzene structure (Gangwer, Goldstein, and Pillay 1978). 
- It is expected on the basis of limited work that the DF for Sr with IRC-718 would be $\sim 10^{4}$ (E. I. du Pont 1981; Chandler 1981).

Description of Organic Anion Exchangers

A group of quaternary ammonium polystyrene, strong-base anion exchange resins was selected for the recovery of Tc from alkaline supernatant. These resins included Dowex $-1, \times 8$, manufactured by Dow Chemical Company; and Amberlite IRA-401, -402 , and -458 , manufactured by Rohm and Haas Company. IRA-458 differs from the other styrene-divinylbenzene resins in that it has an acrylic structure. All of the resins were in the chloride form.

Pretreatment of Ion-Exchange Materials

The ion-exchange materials tested in columns were washed prior to use. Because the inorganic exchangers (IE-95, A-51, and AW-500) generate heat due to hydration when first exposed to water, they were poured into two volumes of distilled water and allowed to cool to ambient temperature prior to use. The resins (IRC-718 and CS-100) and the exchangers were then batch washed with two volumes of $1 \mathrm{M} \mathrm{NaOH}$ for 16 hours with stirring. Each material was then placed in a glass ion-exchange column and backwashed with distilled water until the $\mathrm{pH}$ of the effluent was $<10$. The Dowex $-1, x 8$ anion resin (chloride form) was placed in the ion-exchange column with $\mathrm{H}_{2} \mathrm{O}$ and converted to the nitrate form by pouring $1 \mathrm{M} \mathrm{HNO}_{3}$ through the column at a rate of 1 colume volume/h until the $\mathrm{Cl}^{-}$in the effluent was no longer detectable. The resin was then backwashed with $\mathrm{H}_{2} \mathrm{O}$ until the $\mathrm{pH}$ was $>1$.

Several of the "as-received" exchangers used in column tests were wet sieved to determine their particle size distribution (see Table 2).

The ion-exchange materials used to measure batch sorption ratios were not pretreated prior to use. However, a $1 \mathrm{~g}$ sample of each material tested was dried at $105 \pm 10^{\circ} \mathrm{C}$ for 24 hours and cooled in a desiccator before being reweighed to determine the weight loss due to moisture. A correction factor was applied to each weighed sample used in the batch sorption study. 
TABLE 2. Particle Size Distribution of Wet-Sieved Exchangers

\begin{tabular}{|c|c|c|}
\hline Exchanger & Weight Percent & Mesh Size \\
\hline \multirow[t]{3}{*}{ IE-95 } & 83 & $>40(0.425 \mathrm{~mm})$ \\
\hline & 15 & $60(0.25 \mathrm{~mm})$ \\
\hline & 2 & $80(0.18 \mathrm{~mm})$ \\
\hline \multirow[t]{3}{*}{ IRC-718 } & 25 & $>20(0.85 \mathrm{~mm})$ \\
\hline & 73 & 40 \\
\hline & 2 & $<40$ \\
\hline \multirow[t]{3}{*}{ CS -100} & 22 & $>20$ \\
\hline & 75 & 40 \\
\hline & 3 & $<40$ \\
\hline
\end{tabular}

Procedures for Dynamic Ion-Exchange Loading Tests

The performance of an ion-exchange material in a column can be defined by a breakthrough curve, where the ratio of the effluent concentration ( $C$ ) to the feed concentration ( $\mathrm{CO}$ ) of the ion being removed is plotted as a function of the feed throughput in column volumes (cv). A cv is defined as the volume of the exchanger in an ion-exchange column, including the interstitial void. When the equilibrium is favorable, the ion initially on the bed is displaced and moves faster through the bed than incoming ions, producing a self-sharpening boundary between the loaded and unloaded portions of the bed. The shape of the concentration gradient reaches a steady state within a short distance and remains unchanged as it moves down the column. The breakthrough curve is therefore determined by the steady-state shape of this boundary (Buckingham 1967).

The loading data obtained in this study were plotted using logarithmicprobability graph paper to identify the breakthrough curves. The use of the probability scale for plotting the concentration ratio $\mathrm{C} / \mathrm{Co}_{0}$ and the logarithmic scale for the feed throughput largely eliminates the S-shaped curve obtained with linear scales and makes it possible to plot accurately those values which are either very small or very near unity.

The ion-exchange system shown in Figures 1 and 2 consists of a $1.8-\mathrm{cm}-\mathrm{dia}$ ID glass ion-exchange column, a $27 \mathrm{~L}$ temperature bath used to control the 


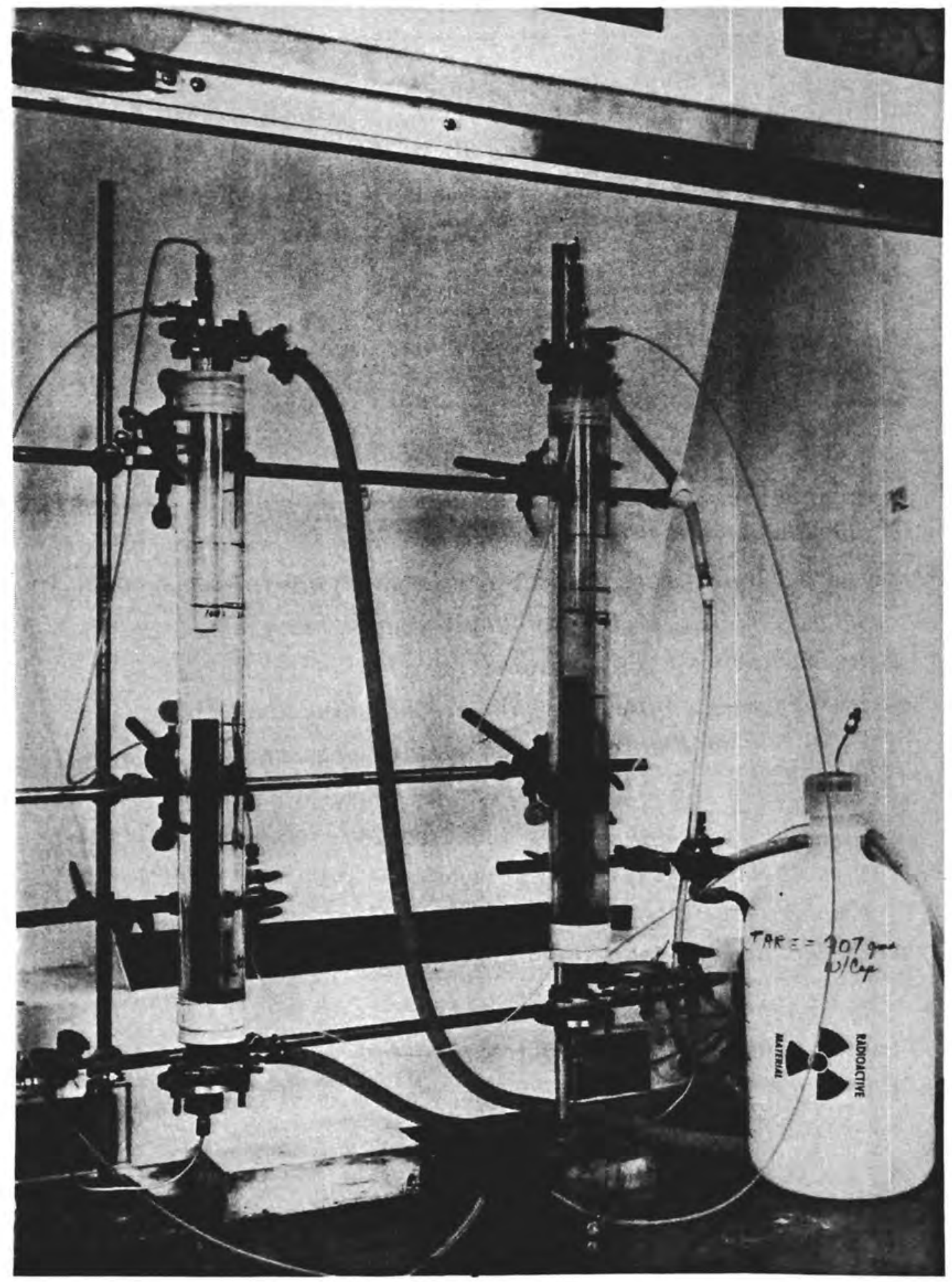

FIGURE 1. Ion-Exchange Columns with a $100 \mathrm{~mL}$ Capacity 


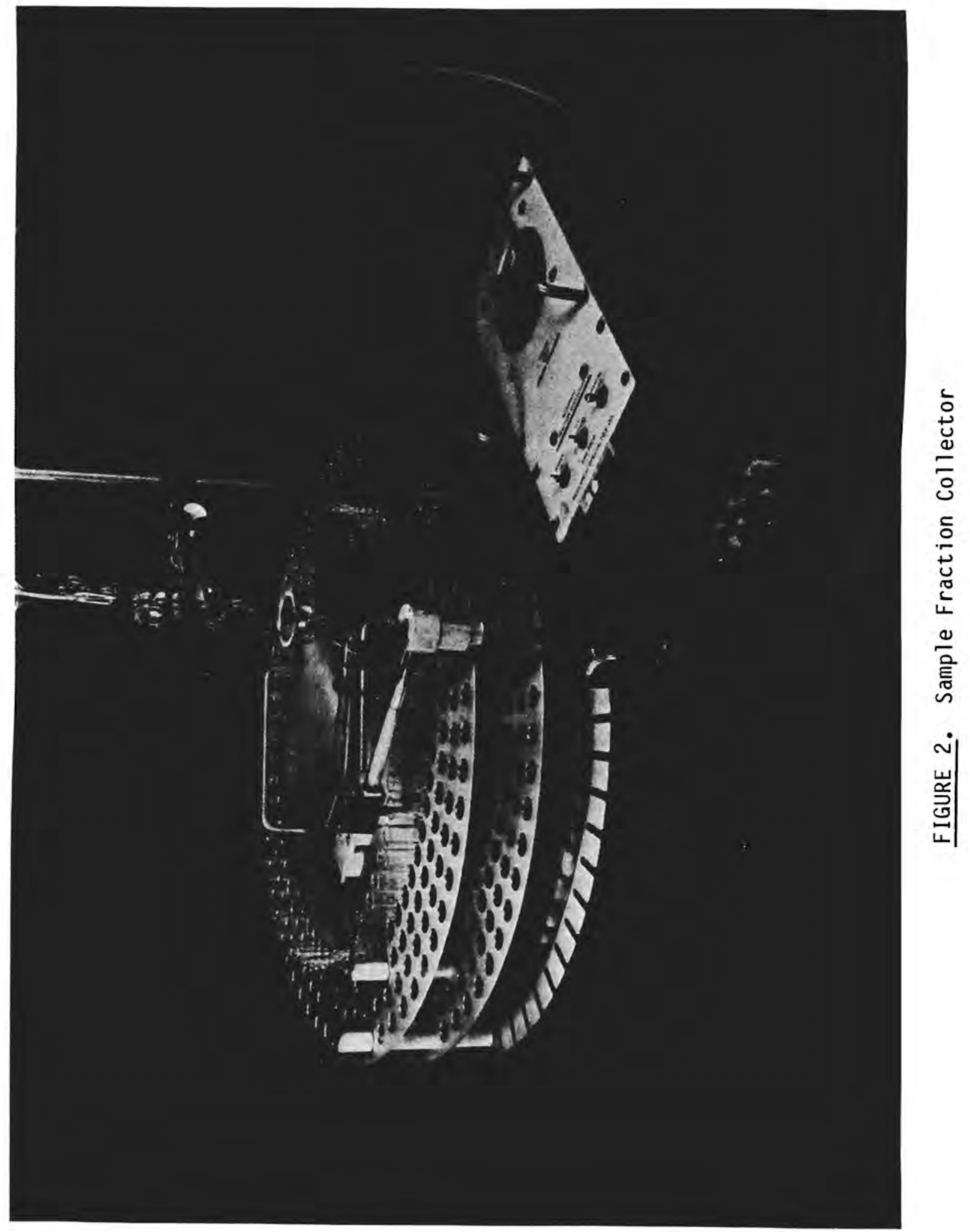


column temperature within a $1^{\circ} \mathrm{C}$ range, a 3 psig pressurized polyethylene feed bottle, and an automatic fraction collector. The ion-exchange column was filled with $100 \mathrm{~mL}$ of exchanger (bed size $39 \mathrm{~cm}$ long $\times 1.8 \mathrm{~cm} \mathrm{dia).} \mathrm{The} \mathrm{column}$ was jacketed with an outer glass column containing circulated ethylene glycolwater for temperature control. The top and bottom of the column were closed using a stainless steel plate and neoprene gasket. The feed to the column from the pressurized ( 3 psig) feed bottle was controlled using a needle valve. The flow rate was checked frequently during each run by counting the number of drops entering the column in a given time period. The effluent from the column was caught in a $20 \mathrm{~mL}$ siphon and transferred to sample tubes in the automatic fraction collector. Selected tubes were then sampled for alpha, beta, or gamma energy analysis. Experiments were completed to examine the column effects of temperature, feed $\mathrm{pH}$, flow rate, and $\mathrm{Na} / \mathrm{Cs}$ mole ratio in the influent feed. 
EXPERIMENTAL RESULTS

A test program designed to provide the experimental data needed to support the selection of treatment processes for alkaline waste being stored at WVNS was completed in four parts: 1) feed preparation and characterization; 2) sludge washing; 3) $\mathrm{Cs}, \mathrm{Sr}$ and Pu recovery from alkaline supernatant by precipitation and sorption processes; and 4) organic and inorganic ion exchange processes for the recovery of $\mathrm{Cs}, \mathrm{Sr}, \mathrm{Pu}$ and $\mathrm{TC}$. Descriptions of the four test procedures are given below.

\section{CHARACTERIZATION OF ALKALINE SUPERNATANT}

Simulated waste solutions representing the West Valley alkaline PUREX waste were prepared to determine the distribution of key radionuclide species between the supernatant and sludge phases prior to sludge washing. The radionuclides studied were Sr, Cs, Pu, Am, Np, Eu, and Tc.

The experimental procedure involved preparation of simulated acidic PUREX waste with the addition of a single radionuclide under study. The acidic PUREX waste was neutralized with excess $\mathrm{NaOH}$ and thoroughly digested. Upon neutralization, a solid phase formed and settled to the bottom of the test beaker. The $\mathrm{pH}$ of the simulated alkaline waste was adjusted to a $\mathrm{pH}$ of $\sim 10$ or $\sim 13$ by $\mathrm{NaOH}$ addition to investigate the effect of hydroxide ion concentration on the solubility of the species under study and the sludge-settling characteristics. A third waste was prepared having a $\mathrm{pH}$ of 13 and containing no carbonate ion to investigate the effect of carbonate on sludge-settling characteristics. Radiochemical concentrations were determined by gamma energy analysis and alpha and beta scintillation counting.

The alkaline waste at West Valley has a $\mathrm{pH}$ of $\sim 10$. We also studied a waste composition with a $\mathrm{pH}$ of $\sim 13$ because it represents an optimum condition for Cs recovery using organic ion exchange.

The sludge-settling experiments showed that $\mathrm{pH}$ and $\mathrm{CO}_{3}=$ concentration had little effect on settling: after 7 days the sludge volume varied from 40 to $48 \%$ of the total volume (Figure 3 ). 


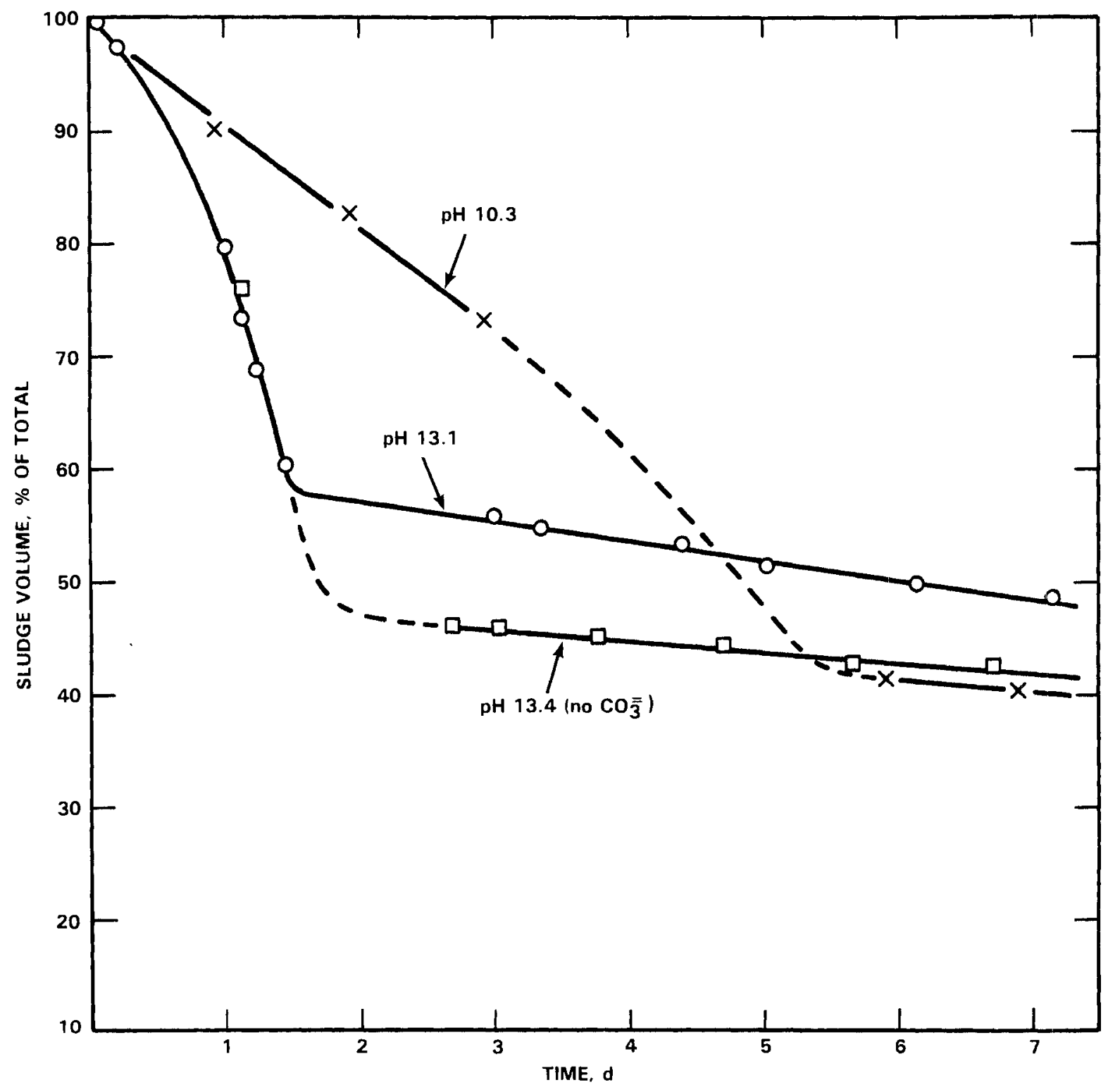

FIGURE 3. Settled Volume of Synthetic West Valley sludge as a Function of Time and $\mathrm{pH}$

Raising the supernatant $\mathrm{pH}$ from 10 to 13 significantly affected the solubility of the radionuclides. A 100-fold decrease in the solubility of Pu, a 10-fold decrease for $\mathrm{Np}$, and a 4-fold decrease for Am and Eu were observed. Cesium, Sr, and TC solubilities were not greatly affected by this change in $\mathrm{pH}$, and were about as expected at $\sim 99 \%, \sim 0.005 \%$ and $290 \%$, respectively. 
If the process using organic ion exchangers is selected for west Valley, then raising the $\mathrm{pH}$ would increase the selectivity of the resin for Cs and aid in $\mathrm{Pu}, \mathrm{Np}$, Am, and Eu recovery by lowering their solubilities.

To simulate and characterize the alkaline waste representing west Valley HLW prepared by the neutralization and precipitation of simulated acidic PUREX waste, the test program was divided into three parts as outlined below. Feed Preparation

The acidic stock solution containing the specific cations and anions found in the West Valley waste is given in Appendix A (Solution A). The $\mathrm{K}^{+}$ion concentration used for this part of the study was $0.069 \mathrm{M}$. Three alkaline wastes were prepared: $\mathrm{pH} 10, \mathrm{pH} 13$ with $\mathrm{NaCO}_{3}$, and $\mathrm{pH} 13$ without $\mathrm{Na}_{2} \mathrm{CO}_{3}$. The carbonate was added to test its effect on the alkaline waste, since initial published West Valley waste compositions did not contain carbonate. [Hanford and Savannah River wastes contain $\mathrm{CO}_{3}{ }^{2}$, and more recent analysis of west Valley waste confirmed that it too contained $\left.\mathrm{CO}_{3}=(0.39 \mathrm{M}).\right]$

Chemical and Physical Analysis

Three alkaline waste solutions were prepared by adjusting an acidic stock solution to $\mathrm{pH} 10, \mathrm{pH} 13$ (with $\left.\mathrm{CO}_{3}{ }^{2}\right)$, and $\mathrm{pH} 13\left(\right.$ no $\left.\mathrm{CO}_{3}{ }^{\circ}\right)$. Each supernatant solution containing precipitated sludge was then tested to determine sludge settling rates, centrifuged solids volume, supernatant $\mathrm{pH}$, and concentration of cations and anions remaining in the supernatant. The effects of time and $\mathrm{pH}$ on the sludge-settling experiments are shown in Figure 3 . The results show that $\mathrm{pH}$ and $\mathrm{CO}_{3}=$ concentration have little effect on settling characteristics after 5 days, and after 7 days the sludge volume varied from 40 to 48 vol\% of the total volume of supernatant and sludge. The pH 10 sludge settled more slowly than the $\mathrm{pH} 13$ sludge in the first 5 days. The specific gravity for the supernatant varied from 1.32 to 1.34 .

Each of the three supernatant and sludge samples was centrifuged at 1750 gravity. No clear separation was obtained during the first 30 minutes, but after 45 to 90 minutes, the sludge volume was $22,25.2$, and 24 vol\% for $\mathrm{pH}$ $10.3,13.1$, and $13.4\left(\right.$ no $\left.\mathrm{CO}_{3}=\right)$, respectively. 
The analysis of the alkaline supernatant after centrifugation is shown in Table 3. About $30 \%$ of the $\mathrm{Cs}^{+}$is missing from the supernatant. Other cation and anion values are as expected.

Distribution of Radionuclides Between Supernatant and Sludge

Alkal ine wastes were prepared by adding tracers of $\mathrm{Cs}, \mathrm{Sr}, \mathrm{Pu}, \mathrm{Np}, \mathrm{Eu}, \mathrm{Am}$, and $T c$ to acidic stock solutions before precipitation. The mole concentration of nonradioactive $\mathrm{Sr}$ and $\mathrm{Cs}$ was followed by using tracers ${ }^{85} \mathrm{Sr}$ and ${ }^{137} \mathrm{Cs}$. Technetium-99 was added, representing the molar concentration found in the west Valley alkaline waste. A ${ }^{152-154}$ Eu tracer was added to follow all of the rare

TABLE 3. Analysis of Synthetic Alkaline Supernatant

\begin{tabular}{|c|c|c|c|c|c|c|c|}
\hline & $\frac{\mathrm{pH} 10}{\mathrm{~g} / \mathrm{L}}$ & $\frac{e^{(a)}}{M}$ & $\frac{\mathrm{pH} 13 \text { Was }}{\mathrm{g} / \mathrm{L}}$ & $\frac{\text { (b) }{ }_{\mathrm{w} / \mathrm{CO}_{3}}}{M}=$ & $\frac{\mathrm{pH} 13 \text { Wast }}{\text { Conc. }}$ & c), $\frac{N}{M}$ & $\frac{\text { No } \mathrm{CO}_{3}}{\mathrm{M}}$ \\
\hline $\mathrm{Na}$ & $2.2 E+2$ & $9.3 E+0$ & $2.0 E+2$ & 8.7 E+0 & $1.9 E+2$ & 8.3 & $E+0$ \\
\hline k & $3.8 \mathrm{E}-1$ & $1.0 \mathrm{E}-2$ & $4.0 \mathrm{E}-1$ & $1.0 \mathrm{E}-2$ & $4.0 E-1$ & 1.0 & $E-2$ \\
\hline Cs & $9.2 \mathrm{E}-2$ & $6.9 \mathrm{E}-4$ & $1.1 \mathrm{E}-1$ & $7.8 \quad E-4$ & $9.8 E-2$ & 7.4 & $E-4$ \\
\hline Mo & $4.6 \mathrm{E}-1$ & $5.0 \quad E-3$ & $5.4 \mathrm{E}-1$ & $6.0 \mathrm{E}-3$ & $5.6 \mathrm{E}-1$ & 6.0 & $E-3$ \\
\hline $\mathrm{Cr}$ & $2.8 E-3$ & $5.4 \mathrm{E}-5$ & $3.4 E-2$ & $6.5 \mathrm{E}-4$ & $8.0 \mathrm{E}-2$ & 1.5 & $E-3$ \\
\hline $\mathrm{Fe}$ & $1.6 \mathrm{E}-3$ & $2.9 E-5$ & $2.0 \mathrm{E}-4$ & $3.6 \mathrm{E}-6$ & $3.0 \mathrm{E}-4$ & 5.4 & $E-6$ \\
\hline$P$ & $7.0 \mathrm{E}-1$ & $2.3 E-2$ & $1.9 E+0$ & $6.1 \mathrm{E}-2$ & $2.0 E+0$ & 7.1 & $E-2$ \\
\hline $\mathrm{CO}_{3}=$ & -- & $3.2 \mathrm{E}-1$ & -- & $5.0 \mathrm{E}-1$ & - & $\mathrm{ND}^{\prime}$ & \\
\hline Si & $3.0 \mathrm{E}-4$ & $1.0 \mathrm{E}-4$ & $4.6 \mathrm{E}-1$ & $1.6 \mathrm{E}-2$ & $4.2 \mathrm{E}-1$ & 1.5 & $E-2$ \\
\hline B & 8.0 E-4 & 7.4 E-4 & $3.6 \mathrm{E}-1$ & $3.3 E-2$ & $2.8 E-1$ & 2.6 & $E-2$ \\
\hline $\mathrm{OH}^{-}$ & -- & -- & -- & -- & -- & 2.8 & $E-1$ \\
\hline $\mathrm{Cl}^{-}$ & $1.5 \mathrm{E}-1$ & 4.3 E-3 & $1.5 \mathrm{E}-1$ & $4.3 E-3$ & $1.5 \mathrm{E}-1$ & 4.3 & $E-3$ \\
\hline $\mathrm{NO}_{3}{ }^{-}$ & $1.9 E+2$ & $3.1 E+0$ & $1.9 E+2$ & $3.1 E+0$ & $1.9 E+2$ & 3.1 & $E+0$ \\
\hline $\mathrm{NO}_{2}^{-}$ & $7.8 E+1$ & $1.7 E+0$ & $7.5 E+1$ & $1.6 E+0$ & $7.8 E+1$ & 1.7 & $E+0$ \\
\hline $\mathrm{SO}_{4}=$ & $2.8 E+1$ & $2.9 E-1$ & $2.8 E+1$ & $2.9 E-1$ & $2.8 E+2$ & 2.9 & $E-1$ \\
\hline
\end{tabular}
(a) Actual pH 10.3.
(b) Actual pH 13.1.
(c) Actual $\mathrm{pH} 13.4$.
(d) Not detectable. 
earths (RE). Plutonium, Np, and Am were not added to the concentrations assumed to be in the tank, but only to a concentration sufficient to determine the solubility limit for each of the actinides. The solubility in alkaline supernatant and the percent between sludge and supernatant were determined for each tracer. The percent found in each phase does not necessarily represent actual West valley tank conditions, and only solubility values should be applied.

Summarized in Table 4 are the distributions and solubility limits of the radiochemical species studied for the two pHs.

Tables 5, 6, and 7 summarize the data obtained for alkaline supernatant preparation using tracers of ${ }^{137} \mathrm{Cs},{ }^{85} \mathrm{Sr}$, and ${ }^{154} \mathrm{Eu}$. The results were obtained by counting $4 \mathrm{~mL}$ samples using a multichannel gamma analyzer that uses a $7.6 \mathrm{~cm}$ dia well $\mathrm{NaI}$ crystal detector.

Tables 8 through 11 summarize the data obtained for alkaline supernatant preparation using tracers of ${ }^{99} \mathrm{Tc},{ }^{238} \mathrm{Pu},{ }^{237} \mathrm{~Np}$, and ${ }^{241} \mathrm{Am}$. The results for $\mathrm{Pu}$ were obtained by extracting aqueous samples into HDEHP-PCS. (a) Technetium, Am, and Np samples were mixed with PCS. All of the samples were counted using a liquid scintillation detector.

LABORATORY SLUDGE WASHING STUDIES

The current approach for treatment of the alkaline PUREX waste stored at West Valley in Tank 8D2 involves separation of the sludge and supernatant, and washing of the resultant sludge to remove soluble salts. The sludge washing procedure used is described in Appendix B. The objective of this work was to determine chemical and radiochemical distributions for the various chemical and radiochemical species between the simulated sludge and supernatant phases during the sludge-washing process. Two scenarios were investigated: 1) waste as it exists at a pH of 10 or 13, and 2) $\mathrm{Na}-\mathrm{TiA}$ added to the waste to effect $\mathrm{Pu}$ and $\mathrm{Sr}$ precipitation prior to sludge separation and washing.

(a) HDEHP: di(2-ethylhexyl)phosphoric acid. PCS: a proprietary reagent of Amersham Corp. 
TABLE 4. Distributions and Concentrations of Radiochemical Species in West Valley Alkaline Waste

\begin{tabular}{ccc} 
Total & \multicolumn{2}{c}{$\mathrm{pH} \sim 10$} \\
\cline { 2 - 3 } $\begin{array}{c}\text { Concentration(a) in } \\
\text { West Valley Waste, } \mathrm{M}\end{array}$ & $\begin{array}{c}\text { Solubility } \\
\text { Limit in } \\
\text { Supernatant, } M\end{array}$ & $\begin{array}{c}\text { Percent }(b) \text { in } \\
\text { Supernatant }\end{array}$ \\
\hline $1.0 \mathrm{E}-3$ & $>1.0 \mathrm{E}-3$ & $\sim 1.0 \mathrm{E}+2$ \\
$5.4 \mathrm{E}-4(\mathrm{c})$ & $2.2 \mathrm{E}-8$ & $4.1 \mathrm{E}-3$ \\
$6.4 \mathrm{E}-4$ & $5.7 \mathrm{E}-4$ & $8.8 \mathrm{E}+1$ \\
$4.4 \mathrm{E}-3$ & $2.1 \mathrm{E}-5$ & $4.7 \mathrm{E}-1$ \\
$7.4 \mathrm{E}-5$ & $3.3 \mathrm{E}-10$ & $4.5 \mathrm{E}-4$ \\
$1.5 \mathrm{E}-5$ & $3.4 \mathrm{E}-9$ & $2.3 \mathrm{E}-2$ \\
$6.8 \mathrm{E}-5$ & $8.6 \mathrm{E}-5$ & $1.0 \mathrm{E}+2$
\end{tabular}

\begin{tabular}{|c|c|}
\hline $\begin{array}{l}\text { Solubility } \\
\text { Limit in } \\
\text { Supernatant }\end{array}$ & $\begin{array}{l}\text { Percent }(b) \text { in } \\
\text { Supernatant }\end{array}$ \\
\hline$>9.8 \quad E-4$ & $9.8 E+1$ \\
\hline $2.7 \quad E-8$ & $5.0 E-3$ \\
\hline $5.8 E-4$ & $9.2 E+1$ \\
\hline $\begin{array}{l}5.2 \text { E-6 } \\
N D(e)\end{array}$ & $1.2 \mathrm{E}-1$ \\
\hline 7.9 E-10 & $5.3 E-3$ \\
\hline $8.6 E-6$ & $1.3 \mathrm{E}+1$ \\
\hline
\end{tabular}

\footnotetext{
(a) Supernatant + sludge.

(b) Percent calculated by dividing solubility limit by total concentration.

(c) Current value assumed for West Valley, $2.7 \times 10^{-5}$, was used in this study.

(d) Europium tracer was followed and is assumed to represent all the rare earths.

(e) $\mathrm{ND}=$ not detectable.
} 
TABLE 5. Cesium Tracer Tests in Alkaline Supernatant

\section{Parameter}

Specific gravity, $\mathrm{g} / \mathrm{cm}^{3}$

Initial volume of stock $A, m$ (a)

Final total volume, $\mathrm{mL}$ (b)

Cs concentration in stock $A, \underline{M}$

Cs concentration in supernatant, $M$ Initial Cs in final supernatant, $\%$
$\mathrm{pH} 10.0 \quad \mathrm{pH} 12.8$

$1.32 \quad 1.32$

$120 \quad 120$

$216 \quad 222$

$1.8 \mathrm{E}-3 \quad 1.8 \mathrm{E}-3$

$1.0 \mathrm{E}-3 \quad 9.8 \mathrm{E}-4$

$98.1 \quad 99.5$

(a) PUREX acid waste (see Appendix A).

(b) Supernatant + sludge.

TABLE 6. Strontium Tracer Tests in Alkaline Supernatant

\section{Parameter}

Specific gravity, $\mathrm{g} / \mathrm{cm}^{3}$

Initial volume of stock $A, \mathrm{~mL}^{(a)}$

Final total volume, $\mathrm{mL}^{(b)}$

Sr concentration in stock $A, M$

Sr concentration in supernatant, $M$

Initial $\mathrm{Sr}$ in final supernatant,
$\mathrm{pH} 10.1 \quad \mathrm{pH} 12.8$

$1.32 \quad 1.32$

$120 \quad 120$

$218 \quad 220$

4.6 E-5 4.6 E-5

$2.2 \mathrm{E}-8 \quad 2.7 \mathrm{E}-8$

0.09

(a) PUREX acid waste (see Appendix A).

(b) Supernatant + sludge.

TABLE 7. Europium Tracer Tests in Alkaline Supernatant

Parameter

Specific gravity, $\mathrm{g} / \mathrm{cm}^{3}$

Initial volume of stock $A, m(a)$

Final total volume, $\mathrm{mL}^{(b)}$

Eu concentration in stock $A, \underline{M}$

Eu concentration in supernatant, $M$

Initial Eu in final supernatant, $\%$
$\mathrm{pH} 9.9 \quad \mathrm{pH} 13.5$

$1.33 \quad 1.34$

$120 \quad 120$

$218 \quad 221$

$7.3 \mathrm{E}-3 \quad 7.3 \mathrm{E}-3$

$2.1 \mathrm{E}-5 \quad 5.2 \mathrm{E}-6$

$0.52 \quad 0.12$

(a) PUREX acid waste (see Appendix A).

(b) Supernatant + sludge. 
TABLE 8. Technetium Tracer Tests in Alkaline Supernatant

\begin{tabular}{|c|c|c|}
\hline Parameter & $\mathrm{pH} 9.7$ & $\mathrm{pH} 13.1$ \\
\hline Specific gravity, $\mathrm{g} / \mathrm{cm}^{3}$ & 1.32 & 1.34 \\
\hline Initial volume of stock $A, m L(a)$ & 120 & 120 \\
\hline Final total volume, $\mathrm{mL}^{(\mathrm{b})}$ & 214 & 218 \\
\hline Tc concentration in stock $A, \underline{M}$ & $1.1 \mathrm{E}-1$ & $1.1 \mathrm{E}-1$ \\
\hline Tc concentration in supernatant, $\underline{M}$ & $5.6 \mathrm{E}-2$ & $5.8 \mathrm{E}-2$ \\
\hline Initial $T c$ in final supern & 88.4 & 92.7 \\
\hline
\end{tabular}

(a) PUREX acid waste (see Appendix A).

(b) Supernatant + sludge.

TABLE 9. Plutonium Tracer Tests in Alkaline Supernatant

\begin{tabular}{|c|c|c|}
\hline Parameter & $\mathrm{pH} 10.0$ & $\mathrm{pH} 13.1$ \\
\hline Specific gravity, $\mathrm{g} / \mathrm{cm}^{3}$ & 1.35 & 1.34 \\
\hline Initial volume of stock $A, \mathrm{~mL}^{(a)}$ & 120 & 120 \\
\hline Final total volume, $\mathrm{mL}^{(\mathrm{b})}$ & 214 & 218 \\
\hline Pu concentration in stock $A, \underline{M}$ & $1.4 \mathrm{E}-8$ & $1.4 E-8$ \\
\hline Pu concentration in supernatant, $\underline{M}$ & $3.3 E-10$ & $N D(c)$ \\
\hline Initial Pu in final supernatant, $\%$ & 4.1 & ND \\
\hline
\end{tabular}

(a) PUREX acid waste (see Appendix A).

(b) Supernatant + sludge.

(c) $N D=$ not detectable.

The major findings of this study are:

- Levels of $\mathrm{SO}_{4}{ }^{2}$ were reduced in the sludge phase to an equivalent loading of $\leq 1 \mathrm{wt} \% \mathrm{Na}_{2} \mathrm{SO}_{4}$ in the waste glass after four water washes.

- Levels of $\mathrm{Na}$ were reduced in the sludge phase to an equivalent loading of $<7 \mathrm{wt} \% \mathrm{Na}_{2} \mathrm{O}$ in the waste glass after four water washes. 
TABLE 10. Neptunium Tracer Tests in Alkaline Supernatant

Parameter

Specific gravity, $\mathrm{g} / \mathrm{cm}^{3}$

Initial volume of stock $A, \mathrm{~mL}(\mathrm{a})$

Final total volume, $\mathrm{mL}(\mathrm{b})$

Np concentration in stock $A, \underline{M}$

Np concentration in supernatant, $\underline{M}$

Initial $\mathrm{Np}$ in final supernatant, $\%$
$\mathrm{pH} 10.1 \quad \mathrm{pH} 13.3$

$1.33 \quad 1.33$

$120 \quad 120$

$218 \quad 220$

$5.8 \quad E-4 \quad 5.8 \quad E-4$

$8.6 \mathrm{E}-5 \quad 8.6 \mathrm{E}-6$

27

2.7

(a) PUREX acid waste (see Appendix A).

(b) Supernatant + sludge.

TABLE 11. Americium Tracer Tests in Alkaline Supernatant

\begin{tabular}{|c|c|c|}
\hline Parameter & $\mathrm{pH} 9.9$ & $\mathrm{pH} 13.7$ \\
\hline Specific gravity, $\mathrm{g} / \mathrm{cm}^{3}$ & 1.34 & 1.34 \\
\hline Initial volume of stock $A, \mathrm{~mL}$ (a) & 120 & 120 \\
\hline Final total volume, $\mathrm{mL}^{(b)}$ & 218 & 220 \\
\hline Am concentration in stock $A, \underline{M}$ & $4.2 E-6$ & $4.2 E-6$ \\
\hline Am concentration in supernatant, $\underline{M}$ & $3.4 E-9$ & $7.9 E-10$ \\
\hline Initial Am in final supernatant, $\%$ & 0.15 & 0.04 \\
\hline
\end{tabular}

(a) PUREX acid waste (see Appendix A).

(b) Supernatant + sludge.

- The $\mathrm{pH}$ of the four successive $\mathrm{H}_{2} \mathrm{O}$ washes remained constant (similar to the supernatant $\mathrm{pH}$ ).

- The addition of Na-TiA to the simulated sludge-supernatant resulted in a DF of only 6.5 for $\mathrm{Sr}$ and 5.1 for $\mathrm{Pu}$, versus $10^{3}$ and 400 , respectively, when added to supernatant only.

- Greater than 98\% of the Sr, Pu, Eu, and Am remained in the sludge after four water washes.

- Both CS and TC washed out of the sludge similar to Na (i.e., 3 to 9\% remained in the sludge after four water washes). 
- The amount of Np was split between the supernatant (39\%) and the washed sludge $(60 \%)$.

The West Valley sludge may not wash as efficiently as the simulated sludge because it may not be possible to remove the wash solution to the same degree as in the laboratory centrifuge study. Thus, it is expected that more than four washes will be required. From experimental data, it is concluded that the addition of $\mathrm{Na}-\mathrm{TiA}$ to the combined sludge-supernatant mixture would not be effective; it should be added to the supernatant only. The results are shown in the following sections.

Figure 4 shows the percent of total Cs remaining in sludge fraction as a function of number of wash steps for two cases: pH 10 waste, and pH 10 waste with $\mathrm{Na}-\mathrm{TiA}$ (see Table 12 for detailed radiochemical data). Cesium and Tc are very similar to $\mathrm{Na}$ in washing characteristics. Approximately $4 \%$ of the $\mathrm{Na}, \mathrm{Cs}$, and Tc remains in the sludge after four water washes. Adding $\mathrm{Na}-\mathrm{TiA}$ reduces washing efficiency.

Table 13 shows the percent of the total $\mathrm{Sr}$ and $\mathrm{Pu}$ in the final supernatant after four washes, with and without $\mathrm{Na}-\mathrm{TiA}$. Note that Pu was not added to the simulated waste in the same concentration as in the actual waste. Only enough Pu was added to assure that it was present in quantities greater than its solubility limit, so the percentages of $\mathrm{Pu}$ in Table 13 can be used only to determine DFs, not absolute quantities. The DF for the Na-TiA addition is only 6.5 for $\mathrm{Sr}$ and 5.1 for Pu. This is compared to a DF of $10^{3}$ and 400 for $\mathrm{Sr}$ and $\mathrm{Pu}$, respectively, when $\mathrm{Na}-\mathrm{TiA}$ is added to the supernatant only.

Chemical Species

Figures 5 through 8 show the effect of the washing process on the amounts of $\mathrm{Na}^{+}, \mathrm{NO}_{2}{ }^{-}, \mathrm{NO}_{3}{ }^{-}$, and $\mathrm{SO}_{4}{ }^{-}$in the simulated sludge. The graphs are presented as percent of the total quantity of a chemical species remaining in the sludge fraction as a function of the number of wash steps. Each graph has four plots, one for each of the four cases studied: $\mathrm{pH} 10$ and $\mathrm{pH} 13$, with and without $\mathrm{Na}-\mathrm{TiA}$. Quantities of $\mathrm{Na}^{+}, \mathrm{NO}_{2}{ }^{-}, \mathrm{NO}_{3}{ }^{-}$, and $\mathrm{SO}_{4}{ }^{-}$and other chemical species are presented in Tables 14 through 17. 


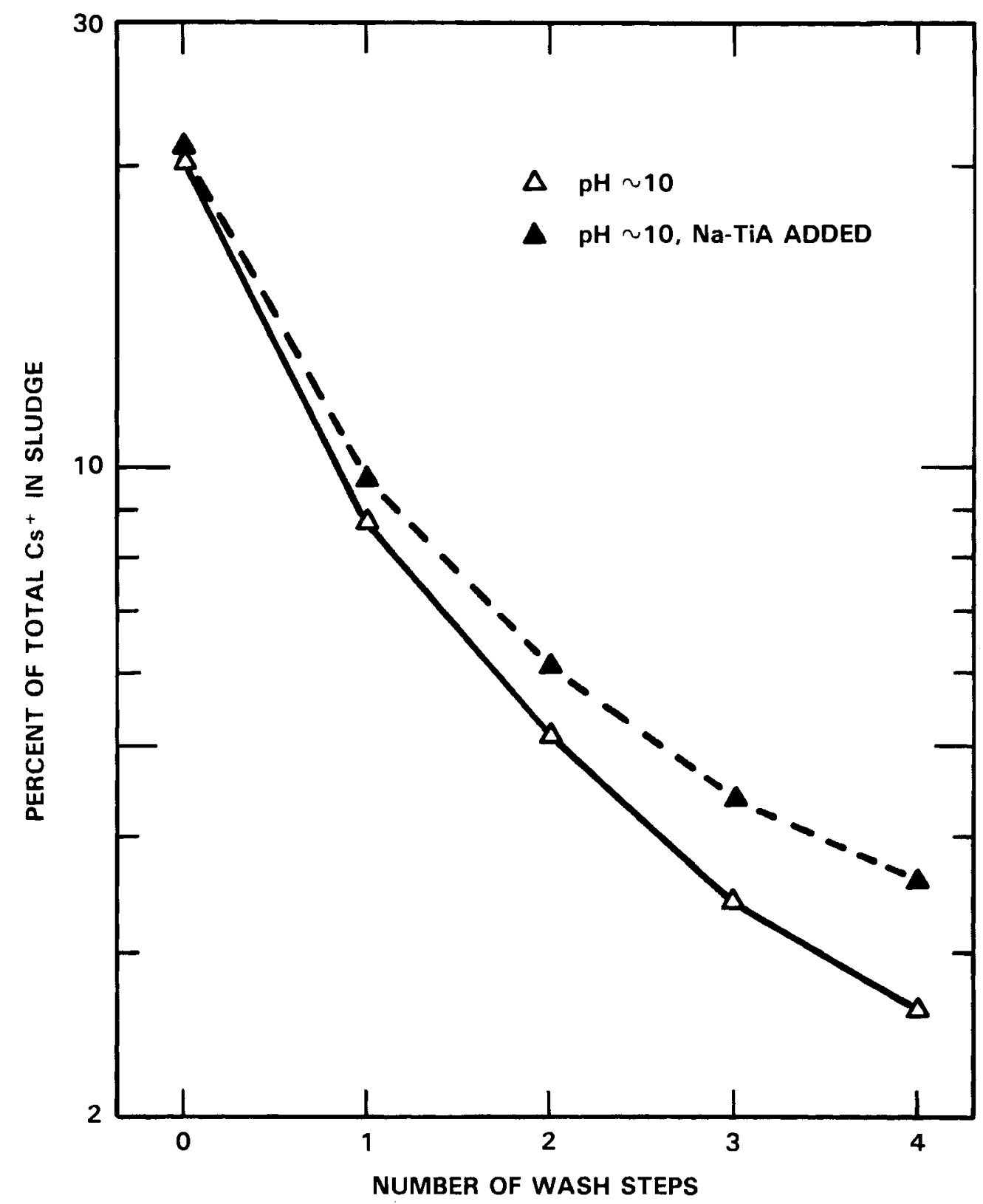

FIGURE 4. Percent of Total $\mathrm{Cs}^{+}$in Sludge as a Function of the Number of Wash Steps

For all species plotted, the case of $\mathrm{pH} \sim 10$ with no $\mathrm{Na}-\mathrm{TiA}$ shows the highest washing efficiency. The sulfate ion was reduced in all cases to $<4 \%$ remaining in the sludge. This is equivalent to 1 wt\% $\mathrm{Na}_{2} \mathrm{SO}_{4}$ in the waste glass. It is expected, however, that the sludge layer in Tank 8D2 is more 


\section{TABLE 12. Radiochemical Species Washing Data}

\begin{tabular}{|c|c|c|c|c|c|c|c|c|c|c|c|c|}
\hline \multirow[b]{2}{*}{ Description } & \multicolumn{4}{|c|}{ Cesium } & \multicolumn{4}{|c|}{ strontium } & \multicolumn{4}{|c|}{ Plutonium } \\
\hline & $\begin{array}{l}\text { Volume } \\
\text { Decanted, } \\
\text { mL }\end{array}$ & $\begin{array}{c}\mathrm{H}_{2} \mathrm{O} \\
\text { Added, } \\
\mathrm{mL}\end{array}$ & $\mathrm{pH}$ & $\begin{array}{l}\text { Din } \\
\text { Soln. }\end{array}$ & $\begin{array}{c}\text { Volume } \\
\text { Decanted, } \\
\mathrm{mL}\end{array}$ & $\begin{array}{c}\mathrm{H}_{2} \mathrm{O} \\
\mathrm{Add} \theta \mathrm{d}, \\
\mathrm{mL} \\
\end{array}$ & $\mathrm{PH}$ & $\begin{array}{l}\text { Sin } \\
\text { Soln. }\end{array}$ & $\begin{array}{c}\begin{array}{c}\text { Vol ume } \\
\text { Decanted, } \\
\mathrm{mL}\end{array} \\
\end{array}$ & $\begin{array}{r}\mathrm{H}_{2}^{\mathrm{O}} \\
\text { Added, } \\
\mathrm{mL} \\
\end{array}$ & $\mathrm{pH}$ & $\begin{array}{l}\text { x in } \\
\text { soln. }\end{array}$ \\
\hline \multicolumn{13}{|c|}{ Base Case $(p H \sim 10)$} \\
\hline Supernatant & 830 & 375 & 10.9 & 78.6 & 805 & 375 & 10.5 & 0.1 & 810 & 375 & 10.7 & 1.12 \\
\hline Ist Wash & 375 & 230 & 10.6 & 12.7 & 325 & 230 & 10.3 & 0.014 & 390 & 230 & 10.5 & 0.058 \\
\hline 2nd Wash & 230 & 200 & 10.6 & 3.6 & 245 & 200 & 10.3 & 0.005 & 235 & 200 & 10.5 & 0.25 \\
\hline 3rd Wash & 200 & 180 & 10.7 & 1.7 & 225 & 180 & 10.5 & 0.005 & 200 & 180 & 10.6 & 0.024 \\
\hline 4th Wash & 180 & -- & 10.6 & 0.8 & 180 & -- & 10.6 & 0.002 & 180 & - & 10.7 & 0.015 \\
\hline $\begin{array}{l}\text { Oissolved } \\
\text { Sludge }\end{array}$ & 1000 & -- & - & 2.8 & 1000 & - & -- & 99.87 & 1000 & - & - & 98.53 \\
\hline \multicolumn{13}{|c|}{$\mathrm{pH} \sim 10+\mathrm{NaTIA}$} \\
\hline Supernatant & 850 & 375 & 11.0 & 78.1 & 830 & 375 & 10.6 & 0.054 & 840 & 375 & 11.2 & 0.154 \\
\hline Ist Wash & 355 & 230 & 10.9 & 12.2 & 335 & 230 & 10.5 & 0.006 & 365 & 230 & 11.0 & 0.048 \\
\hline 2nd wash & 230 & 200 & 10.7 & 3.6 & 225 & 200 & 10.5 & 0.004 & 230 & 200 & 11.0 & 0.03 \\
\hline 3rd Wash & 200 & 180 & 10.9 & 1.7 & 200 & 180 & 10.7 & 0.0007 & 200 & 180 & 11.2 & 0.037 \\
\hline 4 th Wash & 180 & -- & 11.1 & 0.8 & 180 & -- & 10.8 & 0.0003 & 180 & - & 11.2 & 0.029 \\
\hline $\begin{array}{l}\text { Dissolved } \\
\text { Sludge }\end{array}$ & 1000 & -- & -- & 3.7 & 1000 & -- & -- & 99.98 & 1000 & -- & -- & 99.71 \\
\hline
\end{tabular}

\begin{tabular}{|c|c|c|c|c|c|c|c|c|c|c|c|c|c|c|c|c|}
\hline \multirow[b]{2}{*}{ Description } & \multicolumn{4}{|c|}{ Neptun I um } & \multicolumn{4}{|c|}{ Technetlum } & \multicolumn{4}{|c|}{ Europlum } & \multicolumn{4}{|c|}{ Amerlclum } \\
\hline & $\begin{array}{c}\text { Volume } \\
\text { Decanted, } \\
\mathrm{mL} \\
\end{array}$ & $\begin{array}{c}\mathrm{H}_{2} \mathrm{O} \\
\text { Added, } \\
\mathrm{mL} \\
\end{array}$ & $\mathrm{pH}$ & $\begin{array}{l}8 \text { in } \\
\text { Soln. }\end{array}$ & $\begin{array}{c}\text { Volume } \\
\text { Decanted, } \\
\mathrm{mL} \\
\end{array}$ & $\begin{array}{c}\mathrm{H}_{2}{ }^{\mathrm{O}} \\
\mathrm{Added}, \\
\mathrm{mL}\end{array}$ & $\mathrm{pH}$ & $\begin{array}{l}x \text { In } \\
\text { Soln. }\end{array}$ & $\begin{array}{c}\text { Volume } \\
\text { Decanted, } \\
\text { mL } \\
\end{array}$ & $\begin{array}{c}\mathrm{H}_{2} \mathrm{O} \\
\mathrm{Added}, \\
\mathrm{mL} \\
\end{array}$ & pH & $\begin{array}{l}x \text { in } \\
\text { Soln. } \\
\end{array}$ & $\begin{array}{c}\text { Vol ume } \\
\text { Decanted, } \\
\mathrm{mL} \\
\end{array}$ & $\begin{array}{c}\mathrm{H}_{2} \mathrm{O} \\
\text { Added, } \\
\mathrm{mL} \\
\end{array}$ & $\mathrm{pH}$ & $\begin{array}{l}\text { sin } \\
\text { Soln. }\end{array}$ \\
\hline \multicolumn{17}{|c|}{ Base Case $(p H \sim 10)$} \\
\hline Supernatant & 830 & 375 & 10.4 & 38.8 & 830 & 375 & 10.6 & 75.3 & 830 & 375 & 9.9 & $\sim 0.1$ & 830 & 375 & 10.4 & $\sim 0.1$ \\
\hline Ist wash & 335 & 230 & 10.0 & 1.0 & 335 & 230 & 10.4 & 10.6 & 310 & 230 & 9.9 & $\sim 0.1$ & 335 & 230 & 10.3 & $\sim 0.1$ \\
\hline 2nd Wash & 225 & 200 & 10.2 & 0.2 & 225 & 220 & 10.6 & 3.6 & 225 & 200 & 9.9 & $\sim 0$ & 225 & 200 & 10.4 & $\sim 0$ \\
\hline 3rd Wash & 200 & 180 & 10.0 & 0.1 & 200 & 180 & 10.3 & 1.8 & 200 & 180 & 9.9 & $\sim 0$ & 200 & 180 & 9.6 & $\sim 0$ \\
\hline 4 th Wash & 180 & -- & 10.8 & -- & 180 & -- & 10.4 & -- & 180 & -- & 10.0 & $\infty$ & 180 & - & 9.5 & $\sim 0$ \\
\hline $\begin{array}{l}\text { Dissol ved } \\
\text { Sludge }\end{array}$ & 1000 & -- & -- & 59.9 & 1000 & -- & -- & 8.6 & 1000 & -- & -- & 99.8 & 1000 & -- & -- & 99.8 \\
\hline
\end{tabular}


TABLE 13. Percent of Total $\mathrm{Sr}$ and Pu in Final Washed Supernatant

\begin{tabular}{llll} 
& \multicolumn{2}{c}{$\begin{array}{c}\text { Percent in Final } \\
\text { Supernatant }\end{array}$} \\
\cline { 3 - 4 } Element & $\frac{p H \sim 10}{p H \sim 10}$ & w/Na-TiA & Na-TiA DF \\
Strontium & 0.13 & 0.02 & 6.5 \\
Plutonium & 1.5 & 0.29 & 5.1
\end{tabular}

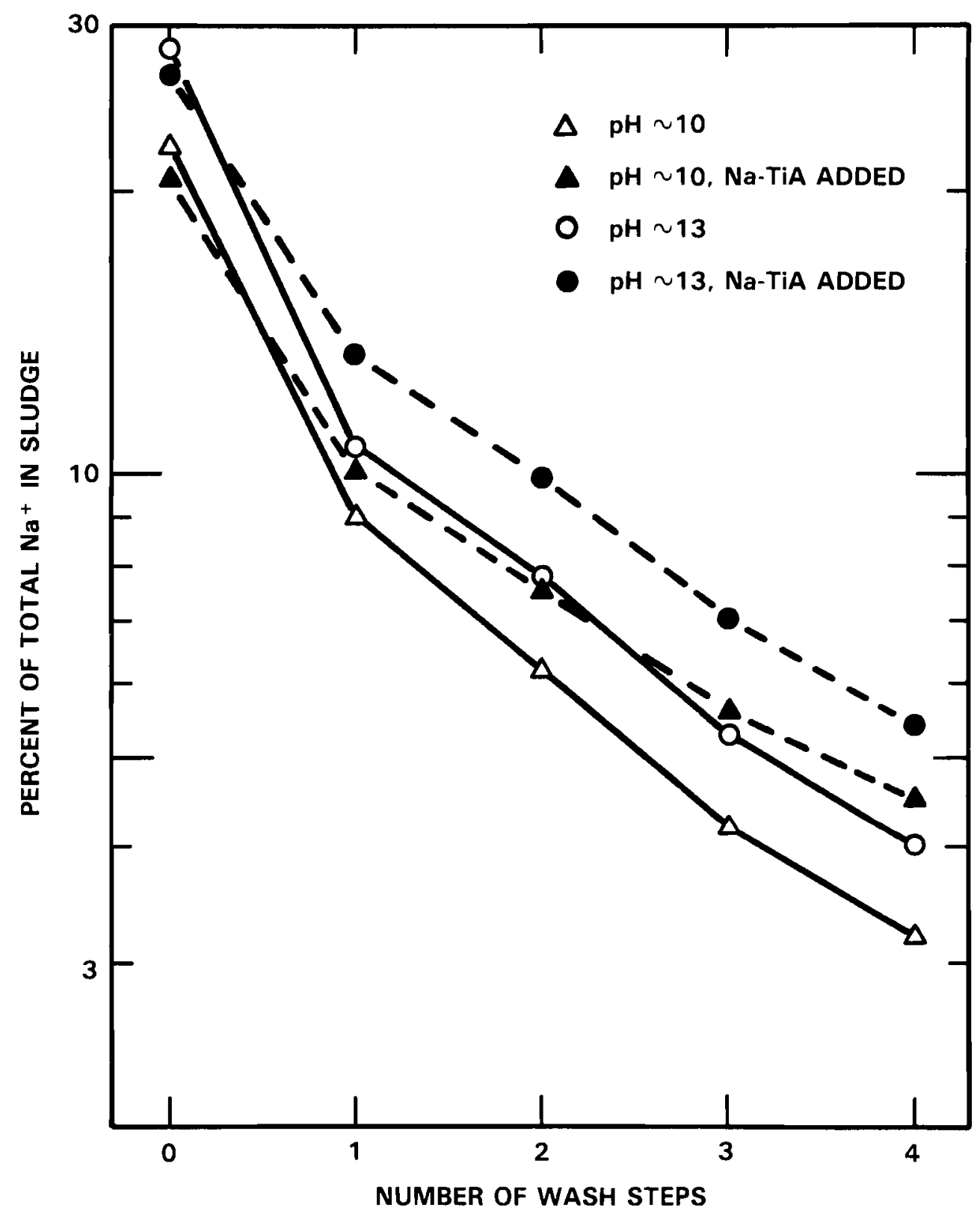

FIGURE 5. Percent of Total $\mathrm{Na}^{+}$in Sludge as a Function of the Number of Wash Steps 


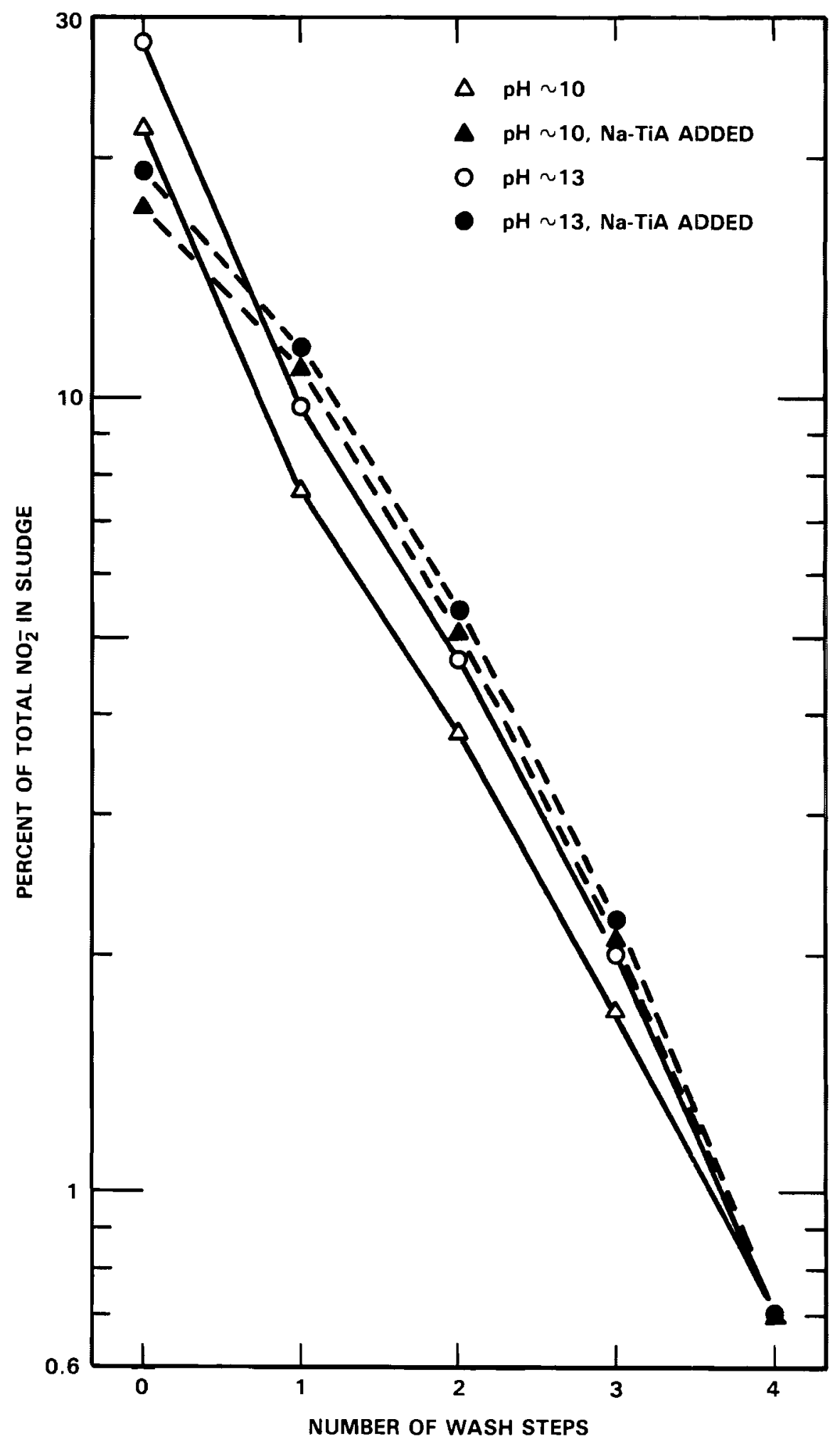

FIGURE 6. Percent of Total $\mathrm{NO}_{2}{ }^{-}$in Sludge as a Function of the Number of Wash Steps 


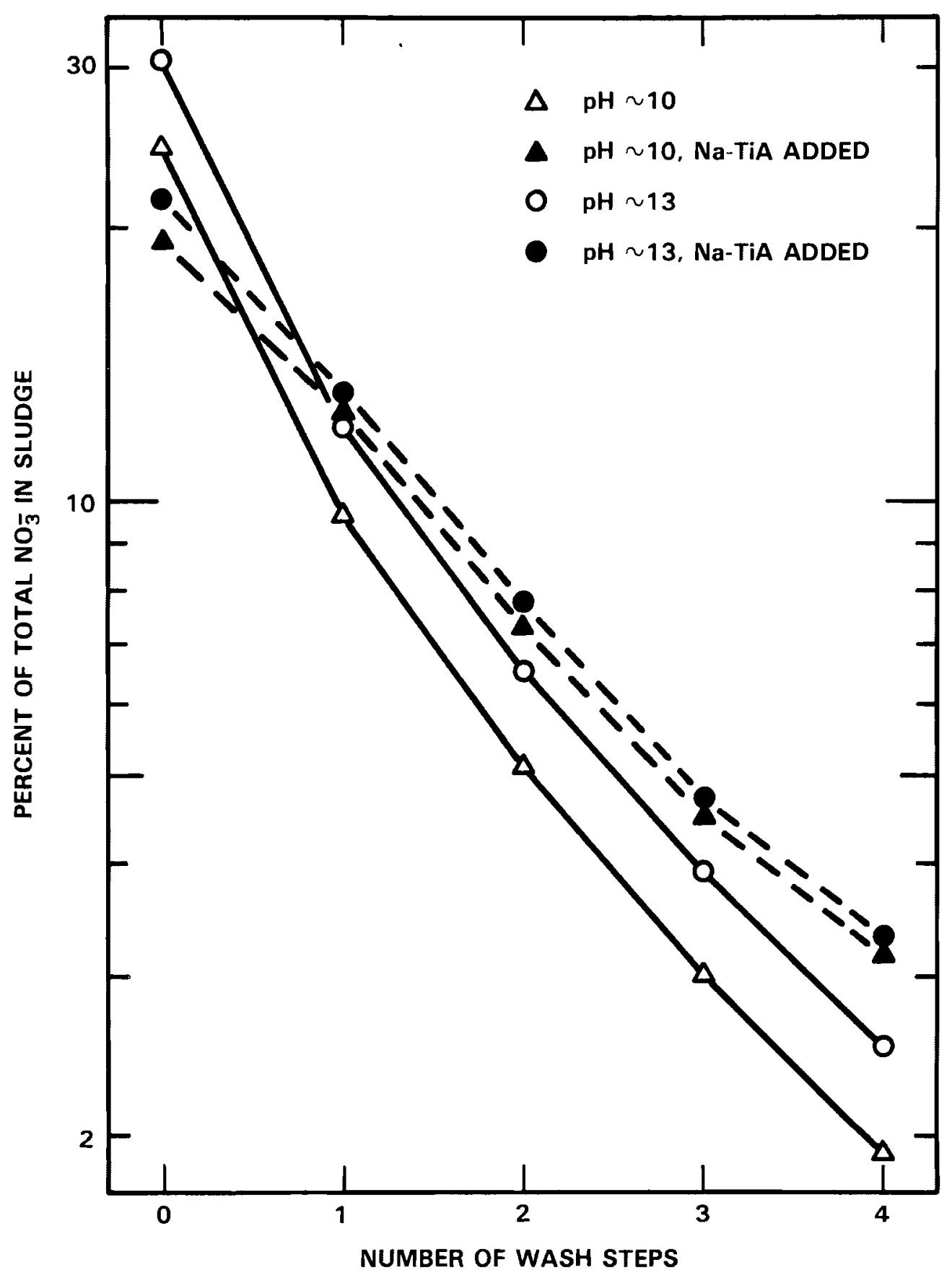

FIGURE 7. Percent of Total $\mathrm{NO}_{3}{ }^{-}$in Sludge as a Function of the Number of Wash Steps 


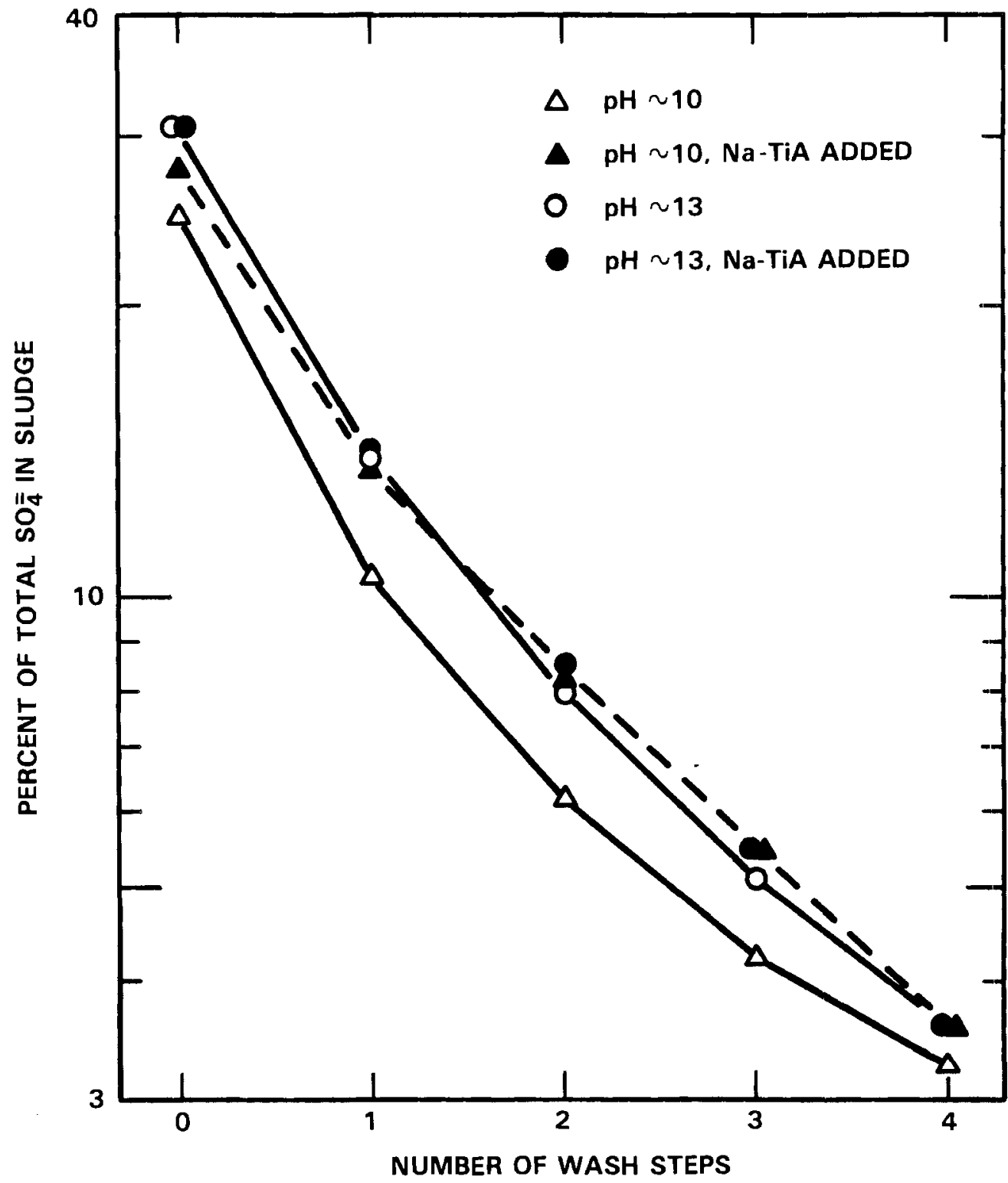

FIGURE 8. Percent of Total $\mathrm{SO}_{4}=$ in Sludge as a Function of the Number of Wash Steps

dense, and it may not be possible to achieve contacting conditions as favorable as in the laboratory.

There was no difference in the $\mathrm{pH}$ of the wash solutions and the supernatant. 
TABLE 14. Chemical Species Washing Data, pH 10

Base Casa $(0+1) \sim 10)$

\begin{tabular}{|c|c|c|c|c|c|c|c|c|c|c|c|c|c|c|c|c|c|c|c|c|c|c|c|c|}
\hline \multirow[t]{2}{*}{ Description } & \multirow{2}{*}{ 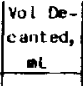 } & \multirow{2}{*}{$\mid$} & \multirow[t]{2}{*}{ pH } & \multicolumn{17}{|c|}{ 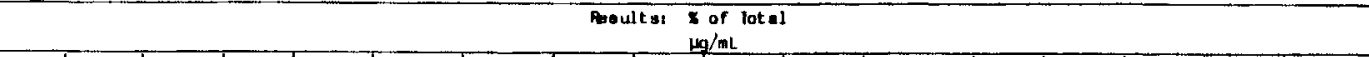 } & \multicolumn{4}{|c|}{ 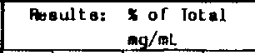 } \\
\hline & & & & AL & E & Be & ce. & cr & $c_{u}$ & $\mathrm{Fe}$ & $\underline{k}$ & $m_{2}$ & $m$ & mo & $\mathrm{NB}$ & nu & $P$ & $s_{1}$ & Sr & 11 & $\mathrm{Cl}^{-}$ & $\mathrm{NO}_{2}$ & $\mathrm{NO}_{3}$ & $\mathrm{SO}_{4}$ \\
\hline Supernat ant & 813 & 373 & 9.5 & 12.2 & ${ }^{50 .}$ & $\begin{array}{l}-- \\
--\end{array}$ & $\begin{array}{l}19.5 \\
5\end{array}$ & $\begin{array}{c}0.26 \\
5\end{array}$ & $\begin{array}{l}30.6 \\
2\end{array}$ & $\begin{array}{c}0.02 \\
5\end{array}$ & $\begin{array}{c}74.7 \\
2600\end{array}$ & $\cdots$ & $\begin{array}{l}-- \\
--\end{array}$ & $\begin{array}{l}72.0 \\
320\end{array}$ & $\begin{array}{ll}77.5 & \\
1.78 & \mathrm{ES}\end{array}$ & $\begin{array}{l}-- \\
--\end{array}$ & $\begin{array}{l}17.0 \\
650\end{array}$ & $\begin{array}{l}6.0 \\
4\end{array}$ & $\begin{array}{l}-- \\
--\end{array}$ & $\ddot{z}$ & $|-\infty|$ & $\begin{array}{l}78.3 \\
83\end{array}$ & $\begin{array}{l}75.6 \\
262\end{array}$ & $\begin{array}{l}75.2 \\
27.3\end{array}$ \\
\hline 'ist wash & 390 & 230 & 9.6 & $\begin{array}{l}0.4 \\
5\end{array}$ & $\begin{array}{l}9.6 \\
2\end{array}$ & $=$ & $\begin{array}{l}7.4 \\
4\end{array}$ & $\begin{array}{l}0.05 \\
2\end{array}$ & $\begin{array}{l}0.7 \\
0.1\end{array}$ & $\begin{array}{c}<0.001 \\
0.4\end{array}$ & $\begin{array}{c}10.7 \\
780\end{array}$ & $\begin{array}{l}-- \\
--\end{array}$ & $\ddot{--}$ & $\begin{array}{l}14.0 \\
130\end{array}$ & $\begin{array}{l}13.5 \\
6.5 \mathrm{E} 4\end{array}$ & $\begin{array}{l}-- \\
--\end{array}$ & 350 & $\begin{array}{l}0.6 \\
0.8\end{array}$ & $\begin{array}{l}-- \\
--\end{array}$ & $\ddot{0.1}$ & $\begin{array}{c}-. \\
<0.3 \\
\end{array}$ & $\begin{array}{l}14.0 \\
11\end{array}$ & $\begin{array}{c}14.8 \\
107\end{array}$ & $\begin{array}{l}14.4 \\
10.9\end{array}$ \\
\hline Znd Mash & 223 & 2013 & 4.8 & $\begin{array}{l}0.2 \\
3.9\end{array}$ & $\begin{array}{l}1.9 \\
0.7\end{array}$ & $\begin{array}{l}-- \\
--\end{array}$ & $\begin{array}{l}1.2 \\
1.1\end{array}$ & $\begin{array}{l}0.02 \\
1.1\end{array}$ & $\begin{array}{l}1.3 \\
0.3\end{array}$ & $\begin{array}{c}<0.001 \\
0.8\end{array}$ & 3.9 & $0 .-$ & $\therefore$ & 6.5 & & -- & $270^{1.95}$ & $\begin{array}{l}0.4 \\
1\end{array}$ & $\ddot{-}$ & $\ddot{i}$ & $<0.3$ & $\begin{array}{l}3.9 \\
15\end{array}$ & 57 & $\begin{array}{r}4.2 \\
5.5\end{array}$ \\
\hline 3rd Wash & 200 & 180 & 9.9 & $\begin{array}{l}0.2 \\
4\end{array}$ & $\begin{array}{l}1.7 \\
0.7\end{array}$ & $\begin{array}{l}-- \\
--\end{array}$ & $\begin{array}{l}0.66 \\
0.7\end{array}$ & $\begin{array}{l}0.000 \\
0.6\end{array}$ & $\begin{array}{l}0.75 \\
0.2\end{array}$ & $\begin{array}{c}0.001 \\
0.5\end{array}$ & $\begin{array}{c}2.3 \\
320\end{array}$ & 0.6 & $\begin{array}{l}-- \\
--\end{array}$ & 3.0 & $\begin{array}{l}2.0 \\
1.9 \leq 4\end{array}$ & $\ddot{-}$ & $225^{1.45}$ & $\begin{array}{l}0.4 \\
1\end{array}$ & $\begin{array}{l}-- \\
--\end{array}$ & $\begin{array}{l}-\cdot \\
--\end{array}$ & $<0.3$ & $\begin{array}{l}2.1 \\
9.2\end{array}$ & ${ }_{29}^{2.1}$ & $\begin{array}{l}1.96 \\
2.9\end{array}$ \\
\hline 4 th Wayh & 180 & $\cdots$ & 9.93 & u. & $\begin{array}{l}0.9 \\
0.4\end{array}$ & $\begin{array}{l}-- \\
--\end{array}$ & $\begin{array}{l}0.3 \\
0.4\end{array}$ & $\begin{array}{l}0.005 \\
0.4\end{array}$ & $\begin{array}{l}1.0 \\
0.3\end{array}$ & $\begin{array}{c}0.001 \\
0.5\end{array}$ & $220^{1.4}$ & -- & $\approx$ & ${ }_{20}^{1.0}$ & $\because$ & $\overline{--}$ & $200^{1.16}$ & $\begin{array}{l}0.7 \\
2\end{array}$ & $\begin{array}{l}-- \\
\cdots\end{array}$ & -- & $<0.3 \mid$ & $\begin{array}{l}1.0 \\
5.0\end{array}$ & $17^{1.1}$ & $\begin{array}{l}0.97 \\
1.6\end{array}$ \\
\hline $\begin{array}{l}\text { pissulved } \\
\text { sludge }\end{array}$ & 3000 & $\mid--$ & -. & $\begin{array}{l}96.8 \\
87\end{array}$ & $\begin{array}{r}55.6 \\
0.9\end{array}$ & $\begin{array}{l}100 \\
6.2\end{array}$ & $\begin{array}{l}71.1 \\
3\end{array}$ & $\begin{array}{l}99.7 \\
310\end{array}$ & $\begin{array}{r}65.7 \\
0.7\end{array}$ & $\begin{array}{c}99.98 \\
3700\end{array}$ & ${ }_{40}^{7.0}$ & $\begin{array}{l}-- \\
--\end{array}$ & $\begin{array}{r}100 \\
74\end{array}$ & $\begin{array}{l}6.9 \\
5\end{array}$ & 1200 & $\begin{array}{l}100 \\
150\end{array}$ & $\begin{array}{l}14.0 \\
460\end{array}$ & $\begin{array}{l}92.0 \\
10\end{array}$ & $\begin{array}{l}100 \\
0.6\end{array}$ & -- & $\begin{array}{l}-- \\
--\end{array}$ & $\begin{array}{l}<0.6 \\
<0.1\end{array}$ & $\begin{array}{l}1.95 \\
1.1\end{array}$ & $\begin{array}{l}3.4 \\
<0.2\end{array}$ \\
\hline $\begin{array}{l}\text { Materia } \\
\text { Batarice }\end{array}$ & & & & 0.45 & 0.008 & 0.031 & 0.021 & 1.56 & 0.0054 & 18.5 & 2.84 & -- & 0.37 & 0.362 & 187.2 & 0.75 & 3.11 & 0.055 & 0.003 & -- & $\cdots \mid \theta$ & 86.4 & 282 & 29.6 \\
\hline
\end{tabular}

TABLE 15. Chemical Species Washing Data, $\mathrm{pH} 10+\mathrm{NaTi}-\mathrm{A}$

Baye Cage pH 10 + Nalxa

\begin{tabular}{|c|c|c|c|c|c|c|c|c|c|c|c|c|c|c|c|c|c|c|c|c|c|c|c|c|}
\hline \multirow[t]{2}{*}{ Description } & \multirow{2}{*}{ 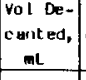 } & \multirow{2}{*}{$\begin{array}{c}\mathrm{H}_{2} \mathbf{0} \\
\text { Added, } \\
\mathrm{mL}\end{array}$} & \multirow[t]{2}{*}{$p+1$} & \multicolumn{17}{|c|}{$\begin{array}{c}\text { Revult s: of lotal } \\
\mathrm{kg} / \mathrm{mL}\end{array}$} & \multicolumn{4}{|c|}{ 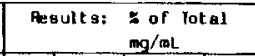 } \\
\hline & & & & Al & 8 & 8 & $\mathrm{Ca}$ & Cr & cu & $\mathrm{Fe}$ & $k$ & $\mathrm{Mg}$ & 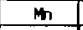 & Ho & $\mathrm{Na}$ & $N_{i}$ & $p$ & $S_{1}$ & Sr & 11 & $\mathrm{Ci}^{-}$ & $\mathrm{NO}_{2}$ & $\mathrm{NO}_{3}$ & $\mathrm{SO}_{4}$ \\
\hline upernat ant & 880 & 37 & 9.9 & $13^{1.4}$ & $\begin{array}{c}78.3 \\
5\end{array}$ & $\because-$ & $\begin{array}{l}17.7 \\
4\end{array}$ & $\begin{array}{l}0.27 \\
5\end{array}$ & $\begin{array}{c}10.2 \\
2\end{array}$ & $\begin{array}{l}0.01 \\
2\end{array}$ & $\begin{array}{c}75.4 \\
2600\end{array}$ & 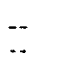 & -- & $\begin{array}{l}79.6 \\
300\end{array}$ & $\begin{array}{l}78.9 \\
1.8 \mathrm{ES}\end{array}$ & $\ddot{-}$ & $\begin{array}{c}16.8 \\
560\end{array}$ & 3.9 & $\begin{array}{l}-- \\
--\end{array}$ & ${ }_{3}^{0.05}$ & \begin{tabular}{l|l}
- & 8 \\
$<0.3$ & 7
\end{tabular} & $\begin{array}{l}82.7 \\
76\end{array}$ & $\begin{array}{l}80.7 \\
245\end{array}$ & $\begin{array}{l}72.4 \\
23.6\end{array}$ \\
\hline ist Wush & 32) & 230 & 10.0 & $\begin{array}{l}0.3 \\
\theta\end{array}$ & $\begin{array}{c}11.6 \\
2\end{array}$ & $=$ & 9.9 & $\begin{array}{l}0.04 \\
2\end{array}$ & $\begin{array}{l}0.5 \\
0.5\end{array}$ & $\begin{array}{l}0.001 \\
0.7\end{array}$ & $130^{7.8}$ & -- & -. & ${ }_{100}^{10.9}$ & $\begin{array}{l}10.3 \\
6.3 \text { E4 }\end{array}$ & -- & 380 & $\begin{array}{l}0.33 \\
0.7\end{array}$ & $\begin{array}{l}-- \\
--\end{array}$ & $\begin{array}{l}0.001 \\
0.2\end{array}$ & $<0.31$ & $\begin{array}{l}6.4 \\
16\end{array}$ & 6.9 & $\begin{array}{l}13.9 \\
12.3\end{array}$ \\
\hline 2nd wash & 225 & 200 & 10.0 & $\begin{array}{l}0.2 \\
7.4\end{array}$ & $\begin{array}{l}4.0 \\
1\end{array}$ & $\begin{array}{l}-- \\
-\end{array}$ & $\begin{array}{l}1.5 \\
1.5\end{array}$ & $\begin{array}{l}0.01 \\
1\end{array}$ & $\begin{array}{l}0.4 \\
0.3\end{array}$ & $\begin{array}{c}0.001 \\
0.3\end{array}$ & 460 & $\begin{array}{l}-. \\
0.9\end{array}$ & $\ddot{-}$ & 6.9 & $\begin{array}{l}2.5 \\
2.2 \mathrm{EA}\end{array}$ & -- & 300 & $\begin{array}{l}0.49 \\
1.5\end{array}$ & $\begin{array}{l}-- \\
--\end{array}$ & $\begin{array}{c}<0.001 \\
0.1\end{array}$ & $--{ }_{0.3}$ & $\begin{array}{r}5.8 \\
20.8\end{array}$ & $\begin{array}{l}5.1 \\
60\end{array}$ & $\begin{array}{l}5.3 \\
6.8\end{array}$ \\
\hline srd mash & 200 & 180 & 10.0 & $\begin{array}{l}0 . \\
\theta\end{array}$ & $\begin{array}{l}3.6 \\
1\end{array}$ & -- & $\therefore$ & $\begin{array}{l}0.009 \\
0.7\end{array}$ & $\begin{array}{l}1.05 \\
0.9\end{array}$ & -- & $330^{2.2}$ & $\begin{array}{l}-- \\
--\end{array}$ & $\begin{array}{l}-- \\
-\end{array}$ & ${ }_{38}^{2.1}$ & $\begin{array}{l}2.0 \\
2 E 4\end{array}$ & -- & $280^{1.9}$ & $\begin{array}{l}0.2 \\
0.7\end{array}$ & $\approx$ & -. & $<0.31$ & $\begin{array}{l}3.0 \\
12.3\end{array}$ & 38 & $\begin{array}{l}2.9 \\
4.2\end{array}$ \\
\hline Ath wash & 180 &.- & 10.2 & ${ }^{0.2}$ & $\begin{array}{l}2.6 \\
0.8\end{array}$ & $=$ & $\begin{array}{l}0.63 \\
0.7\end{array}$ & $\begin{array}{l}0.006 \\
0.5\end{array}$ & $\begin{array}{l}0.6 \\
0.6\end{array}$ & $\begin{array}{c}<0.001 \\
0.4\end{array}$ & $230^{1.4}$ & $\begin{array}{l}-- \\
-\end{array}$ & $\because$ & $\begin{array}{l}1.2 \\
2.4\end{array}$ & $\begin{array}{l}1.1 \\
1.2 \mathrm{E} 4\end{array}$ & $\begin{array}{l}-- \\
--\end{array}$ & 250 & $\begin{array}{l}-- \\
-.\end{array}$ & -. & $\begin{array}{l}-. \\
--\end{array}$ & <0.s & $\begin{array}{l}1.4 \\
6.3\end{array}$ & \begin{tabular}{|c|}
1.35 \\
20
\end{tabular} & $\begin{array}{l}1.9 \\
3.0\end{array}$ \\
\hline $\begin{array}{l}\text { Dessulived } \\
\text { Sl wodge }\end{array}$ & 5000 & -. & -. & $\begin{array}{l}97.7 \\
160\end{array}$ & -. & 100 & 33.3 & $\begin{array}{l}99.7 \\
320\end{array}$ & $\frac{87.1}{3}$ & $\begin{array}{r}100 \\
3600\end{array}$ & 9.9 & $\begin{array}{l}-- \\
--\end{array}$ & $\begin{array}{l}100 \\
73\end{array}$ & $\begin{array}{l}8.4 \\
6\end{array}$ & 1800 & $\begin{array}{l}100 \\
150\end{array}$ & $\begin{array}{c}73.3 \\
430\end{array}$ & $\begin{array}{l}95.1 \\
13\end{array}$ & $\begin{array}{l}100 \\
0.5\end{array}$ & 1100 &.- & $<0.6$ & $\begin{array}{l}3.2 \\
1.7\end{array}$ & $\mid \begin{array}{l}<3.5 \\
<0.2\end{array}$ \\
\hline$\left|\begin{array}{l}\text { Material } \\
\text { Batance. }\end{array}\right|$ & & & & 0.819 & 0.006 & 0.033 & 0.02 & 1.61 & 0.017 & 18.0 & 3.04 & -- & 0.365 & $0.3 ; 9$ & 199.4 & 0.75 & 2.94 & 0.069 & 0.003 & 5.5 & -- & 80.9 & 267 & $28.7 \mid$ \\
\hline
\end{tabular}


TABLE 16. Chemical Species Washing Data, pH 13

\begin{tabular}{|c|c|c|c|c|c|c|c|c|c|c|c|c|c|c|c|c|c|c|c|c|c|c|c|c|}
\hline \multirow{2}{*}{ Desterst tow } & \multirow{2}{*}{$\begin{array}{c}\text { rol De- } \\
\text { cantes, } \\
\text { mL }\end{array}$} & \multirow{2}{*}{\begin{tabular}{c|}
$\mathrm{H}_{2} \mathrm{O}$ \\
Added \\
$\mathrm{mL}$
\end{tabular}} & \multirow{2}{*}{ pH } & \multicolumn{17}{|c|}{ Posult a: $\begin{array}{l}\text { of lotal } \\
\text { ho/al }\end{array}$} & \multicolumn{4}{|c|}{ 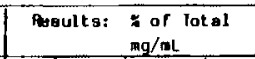 } \\
\hline & & & & A! & B & $\mathrm{Ba}$ & $\mathrm{Ca}$ & cr & cu & Fo & $k \mid$ & $m_{2}$ & $m$ & wo & $\mathrm{Na}$ & $\mathrm{N}_{2}$ & $p$ & $s_{1}$ & sr & $T_{2}$ & $\mathrm{ci}^{-}$ & $\mathrm{NO}_{2}$ & $\mathrm{NO}_{3}$ & $\mathrm{SO}_{4}$ \\
\hline Supecyat ant & 10u & 373 & 12.4 & $15^{1.6}$ & $\begin{array}{l}81.6 \\
350\end{array}$ & $\begin{array}{l}-- \\
--\end{array}$ & $\begin{array}{l}8.7 \\
4\end{array}$ & $\begin{array}{l}0.7 \\
14\end{array}$ & $\begin{array}{c}24.0 \\
2\end{array}$ & $\begin{array}{l}0.008 \\
2\end{array}$ & $\begin{array}{r}68.6 \\
2600\end{array}$ & $\begin{array}{l}-- \\
--\end{array}$ & $\begin{array}{l}\cdots \\
--\end{array}$ & 429.5 & $\begin{array}{l}71.8 \\
1.9 \mathrm{ES}\end{array}$ & -- & \begin{tabular}{|c|}
60.3 \\
1900
\end{tabular} & 370 & $\begin{array}{l}-- \\
--\end{array}$ & $\begin{array}{r}21.8 \\
1.5\end{array}$ & $\mid--$ & $\begin{array}{l}22.1 \\
81\end{array}$ & $\begin{array}{l}69.5 \\
258\end{array}$ & $\begin{array}{l}69.4 \\
24.5\end{array}$ \\
\hline 19t masn & 205 & 290 & 12.5 & 3.2 & 170 & $\begin{array}{l}-- \\
--\end{array}$ & $\begin{array}{l}5.1 \\
4\end{array}$ & $\begin{array}{l}0.2 \\
6\end{array}$ & $\begin{array}{l}0.9 \\
0.1\end{array}$ & $\begin{array}{l}0.001 \\
0.3\end{array}$ & \begin{tabular}{|l|}
13.4 \\
870
\end{tabular} & $\begin{array}{l}-- \\
--\end{array}$ & $\begin{array}{l}- \\
--\end{array}$ & $\begin{array}{l}18.4 \\
190\end{array}$ & $\begin{array}{l}17.5 \\
7.9 \mathrm{Ea}\end{array}$ & $\begin{array}{l}-- \\
--\end{array}$ & $\begin{array}{c}22.3 \\
1200\end{array}$ & $\begin{array}{l}14.9 \\
240\end{array}$ & 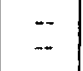 & $\begin{array}{l}0.8 s \\
0.1\end{array}$ & $|--|$ & $\begin{array}{l}18.2 \\
35\end{array}$ & 1117 & $\begin{array}{l}16.6 \\
10.0\end{array}$ \\
\hline $2 n s$ masn & 224 & 200 & 12.2 & $\begin{array}{l}0.07 \\
1.9\end{array}$ & 9.2 & $\ddot{-}$ & $\begin{array}{l}0.65 \\
1\end{array}$ & $\begin{array}{l}0.05 \\
3.5\end{array}$ & $\begin{array}{l}1.7 \\
0.4\end{array}$ & $\begin{array}{l}0.002 \\
1.4\end{array}$ & 54.2 & \begin{tabular}{|l|}
1.0 \\
0.9
\end{tabular} & -- & $\mid \begin{array}{c}4.8 \\
100\end{array}$ & $\begin{array}{l}3.0 \\
2.7 \mathrm{E}_{4}\end{array}$ & $\begin{array}{l}-- \\
--\end{array}$ & $\begin{array}{c}6.3 \\
670\end{array}$ & 22.9 & $=$ & $\begin{array}{l}0.86 \\
0.2\end{array}$ & $\mid-\infty$ & $\begin{array}{c}5.0 \\
19\end{array}$ & 9.6 & $\begin{array}{l}6.1 \\
7.3\end{array}$ \\
\hline ird wasn & 200 & 180 & 12.4 & $\begin{array}{l}0.06 \\
2\end{array}$ & 3.4 & -- & $\ddot{-}$ & $\begin{array}{l}0.025 \\
2\end{array}$ & $\begin{array}{l}0.8 \\
0.2\end{array}$ & $\begin{array}{c}<0.001 \\
0.4\end{array}$ & 380 & $\begin{array}{l}0.6 \\
0.6\end{array}$ & $\begin{array}{l}-- \\
--\end{array}$ & $\begin{array}{l}2.6 \\
60\end{array}$ & $\begin{array}{l}2.4 \\
2.4 \mathrm{E}\end{array}$ & -- & $370^{3.1}$ & 200 & $\begin{array}{l}-- \\
--\end{array}$ & $\because$ & $<0$. & $\begin{array}{r}2.7 \\
11.5\end{array}$ & $37^{2.6}$ & $\begin{array}{l}2.8 \\
3.7\end{array}$ \\
\hline Atn Wash & 180 & -- & 12.2 & $\begin{array}{l}0.03 \\
1\end{array}$ & $\begin{array}{l}1.9 \\
35\end{array}$ & $\begin{array}{l}-- \\
-\cdot\end{array}$ & $\because$ & $\begin{array}{l}0.01 \\
1\end{array}$ & $\begin{array}{l}1.0 \\
0.3\end{array}$ & $\begin{array}{c}0.001 \\
0.6\end{array}$ & 260 & -- & -- & $\frac{1.4}{35}$ & $\begin{array}{l}1.3 \\
1.5 E 4\end{array}$ & 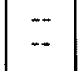 & $2^{1.8}$ & 210 & $\because$. & $\therefore$ & $\begin{array}{c}. . \\
<0.3\end{array}$ & $\begin{array}{l}1.4 \\
6.6\end{array}$ & 22 & $\begin{array}{l}1.5 \\
2.2\end{array}$ \\
\hline $\begin{array}{l}\text { Di gsulived } \\
\text { islooge }\end{array}$ & sous & -- & $\cdots$ & $\begin{array}{l}98.0 \\
120\end{array}$ & 4.6 & $\begin{array}{c}100 \\
5\end{array}$ & $\begin{array}{l}85.6 \\
6\end{array}$ & $\begin{array}{l}99.1 \\
320\end{array}$ & $\begin{array}{r}66.7 \\
0.7\end{array}$ & $\begin{array}{c}49.99 \\
3800\end{array}$ & s.s & $\begin{array}{c}98.4 \\
4\end{array}$ & $\begin{array}{l}100 \\
75\end{array}$ & 3.3 & $\begin{array}{c}4.0 \\
1600\end{array}$ & $\begin{array}{l}100 \\
150\end{array}$ & 30.3 & $\begin{array}{l}28.0 \\
40\end{array}$ & $\begin{array}{c}100 \\
0.6\end{array}$ & $\begin{array}{r}76.5 \\
0.8\end{array}$ & $\begin{array}{l}-- \\
--\end{array}$ & $\begin{array}{l}<0.6 \\
<0.1\end{array}$ & $\begin{array}{l}2.5 \\
1.4\end{array}$ & $\begin{array}{l}<3.7 \\
<0.2\end{array}$ \\
\hline Material & & & & 0.61 & 0.33 & 0.025 & $0.03 \mathrm{~s}$ & 1.62 & 0.005 & 19.0 & 2.88 & 0.02 & 0.375 & 0.46 & 201 & 0.75 & 2.40 & 0.72 & $0.00 s$ & 0.005 & - & 85.4 & 282 & 26.9 \\
\hline
\end{tabular}

TABLE 17. Chemical Species Washing Data, pH $13+\mathrm{Na}-\mathrm{TiA}$

Base Case PH -13 + NalzA

\begin{tabular}{|c|c|c|c|c|c|c|c|c|c|c|c|c|c|c|c|c|c|c|c|c|c|c|c|c|}
\hline \multirow{2}{*}{ Deser rept ion } & \multirow{2}{*}{\begin{tabular}{|c|} 
vol de- \\
canted, \\
mi \\
\end{tabular}} & \multirow{2}{*}{$\begin{array}{c}\begin{array}{c}\mathrm{H}_{2} \mathrm{O} \\
\text { Added, } \\
\mathrm{ml}\end{array} \\
\end{array}$} & \multirow{2}{*}{ prt } & \multicolumn{17}{|c|}{ Fesult 9: $\begin{array}{c}\text { of lot al } \\
\mathrm{g} / \mathrm{mL}\end{array}$} & \multicolumn{4}{|c|}{ Result s: : of lotel } \\
\hline & & & & Al & $B$ & Ba & $\mathrm{C}_{\mathrm{B}}$ & Er & $c_{u}$ & $\overline{F e}$ & $k$ & $m_{2}$ & m & $\bar{m}_{0}$ & $\mathrm{Na}$ & $N_{2}$ & $\mathrm{P}$ & 51 & Sr & 11 & $\mathrm{Cl}^{-}$ & $\mathrm{NO}_{2}$ & $\mathrm{NO}_{3}$ & $50_{9}$ \\
\hline uperisat art & 823 & 373 & 13.1 & 393 & $\frac{68.5}{115}$ & $=$ & $\begin{array}{c}15.6 \\
4\end{array}$ & 9.6 & $\begin{array}{l}7.5 \\
2\end{array}$ & $\begin{array}{l}0.009 \\
2\end{array}$ & $\mid \begin{array}{c}71.2 \\
2500\end{array}$ &.- & $\ddot{-}$ & 31.4 & $\begin{array}{l}73.5 \\
1.8 \mathrm{ES}\end{array}$ & $\begin{array}{l}-- \\
--\end{array}$ & $\begin{array}{c}47.3 \\
1700\end{array}$ & ${ }_{20}^{1.2}$ & $\because$ & $\begin{array}{l}0.01 \\
1\end{array}$ & $|-\overrightarrow{0.3}|$ & $\begin{array}{l}81.8 \\
76\end{array}$ & $\begin{array}{l}78.6 \\
245\end{array}$ & $\begin{array}{l}69.5 \\
23.6\end{array}$ \\
\hline :st 4 ash & 30 & $2 \omega$ & $1: 0$ & 2.3 & $\begin{array}{l}14.2 \\
5.3\end{array}$ & -- & $\begin{array}{l}7.0 \\
4\end{array}$ & 2.0 & $\begin{array}{l}0.5 \\
0.3\end{array}$ & $\begin{array}{l}0.002 \\
1\end{array}$ & $\begin{array}{c}9.6 \\
250\end{array}$ & $\because$ & 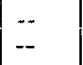 & $\begin{array}{c}15.2 \\
180\end{array}$ & $\begin{array}{l}19.2 \\
7.2 \mathrm{EA}\end{array}$ & $\begin{array}{l}-- \\
--\end{array}$ & $\left|\begin{array}{c}21.2 \\
1700\end{array}\right|$ & $\begin{array}{c}0.3 \\
11\end{array}$ & $\begin{array}{l}-- \\
--\end{array}$ & $\begin{array}{l}0.002 \\
0.3\end{array}$ & $\mid-$. & $\begin{array}{l}7.6 \\
16\end{array}$ & 39.2 & $\begin{array}{l}16.3 \\
12.3\end{array}$ \\
\hline Ind Wash & 253 & 2011 & 12.6 & 4.2 & $\begin{array}{l}5.4 \\
32\end{array}$ & $=$ & 1.1 & so & $\begin{array}{l}0.3 \\
0.3\end{array}$ & $\begin{array}{c}0.001 \\
0.5\end{array}$ & 540 & $\begin{array}{l}0.8 \\
0.7\end{array}$ & $=$ & 10.4 & $\begin{array}{l}3.4 \\
2.9 \mathrm{E} 4\end{array}$ & $\begin{array}{l}-- \\
--\end{array}$ & $\begin{array}{c}7.9 \\
1000\end{array}$ & $\begin{array}{l}0.2 \\
10\end{array}$ & $\begin{array}{l}-- \\
--\end{array}$ & $\begin{array}{l}80.001 \\
0.2\end{array}$ & $\left|\begin{array}{c|}-- \\
0.3\end{array}\right|$ & $\begin{array}{r}6.2 \\
20.6\end{array}$ & 50.5 & 6.8 \\
\hline sid Wash & 2013 & 180 & 12.6 & $44^{1.0}$ & $\begin{array}{c}2.9 \\
20\end{array}$ & $\overline{-}$ & ${ }_{3}^{2.8}$ & $3,0.4$ & $\begin{array}{l}0.5 \\
0.6\end{array}$ & $\begin{array}{l}0.001 \\
1\end{array}$ & $\begin{array}{r}2.8 \\
400\end{array}$ & $\ddot{-}$ & $\because-$ & ${ }_{65}^{3.0}$ & $\begin{array}{l}2.9 \\
2.9 E 4\end{array}$ & $\begin{array}{l}-- \\
--\end{array}$ & 630 & 0.2 & $\because-$ & $\begin{array}{l}-. \\
--\end{array}$ & $\left|\begin{array}{c}- \\
0.3\end{array}\right|$ & $\begin{array}{l}3.2 \\
12.3\end{array}$ & $\begin{array}{l}3.0 \\
38\end{array}$ & $\begin{array}{l}3.0 \\
4.2\end{array}$ \\
\hline$i^{*}$ & 100 & -- & 12.5 & $\begin{array}{l}10.8 \\
39\end{array}$ & 1.8 & $=$ & 3,6 & $\begin{array}{c}0.2 \\
20\end{array}$ & $\because$ & $\begin{array}{c}x .001 \\
0.4\end{array}$ & $\mid \begin{array}{c}1.3 \\
270\end{array}$ & $\because$ & $=$ & 1.6 & $\begin{array}{l}1.5 \\
1.8 \mathrm{EA}\end{array}$ & $\because$ & $\begin{array}{r}2.5 \\
420\end{array}$ & $\begin{array}{l}0.1 \\
10\end{array}$ & $\because$ & $\because$ & $\mid \begin{array}{c}- \\
0.3\end{array}$ & $\begin{array}{l}1.5 \\
6.3\end{array}$ & 20.4 & $\begin{array}{l}1.9 \\
3.0\end{array}$ \\
\hline $\begin{array}{l}\text { Di gsul ived } \\
\text { sl wewge }\end{array}$ & s000 & -- &.. & $\begin{array}{l}89.5 \\
160\end{array}$ & $\begin{array}{l}7.2 \\
2\end{array}$ & $\begin{array}{r}100 \\
6\end{array}$ & $\begin{array}{c}70.9 \\
3\end{array}$ & $\begin{array}{l}87.0 \\
270\end{array}$ & $\begin{array}{c}91.1 \\
4\end{array}$ & $\begin{array}{c}99.99 \\
3700\end{array}$ & $\begin{array}{l}10.4 \\
60\end{array}$ & $\begin{array}{l}99.2 \\
4\end{array}$ & $\begin{array}{r}100 \\
75\end{array}$ & 3.4 & $\begin{array}{r}5.4 \\
2200\end{array}$ & $\begin{array}{l}100 \\
150\end{array}$ & $\begin{array}{c}16.8 \\
100\end{array}$ & $\begin{array}{l}98.0 \\
270\end{array}$ & $\begin{array}{c}100 \\
0.6\end{array}$ & \begin{tabular}{|l|}
99.98 \\
1200
\end{tabular} & $=$ & $<\begin{array}{r}0.6 \\
<0.1\end{array}$ & $\begin{array}{l}3.3 \\
1.7\end{array}$ & $\mid \begin{array}{l}<3.6 \\
<0.2\end{array}$ \\
\hline $\begin{array}{l}\text { Maters } \\
\text { Balanc }\end{array}$ & & & & 0.89 & 0.14 & 0.05 & 0.022 & 1.55 & 0.022 & 18.5 & 2.90 & 0.02 & 0.313 & 0.44 & 202 & 0.73 & 2.97 & 1.38 & 0.003 & 6.0 & -- & 77.6 & 257 & 28.0 \\
\hline
\end{tabular}




\section{Radiochemical Species}

The Cs and Tc in the alkaline waste behaved much like Na. Plutonium and $\mathrm{Sr}$ behave as expected in the alkaline waste; however, when Na-TiA was added to the sludge/supernatant mixture, it failed to achieve the DFs possible when it is added to the supernatant only. We believe that the $\mathrm{Na}-\mathrm{TiA}$ removes the $\mathrm{Sr}$ and $\mathrm{Pu}$ from the supernatant, but that the supernatant then reequilibrates with the Sr- and Pu-laden sludge phase, putting more $\mathrm{Sr}$ and $\mathrm{Pu}$ back into the supernatant. It is not feasible, then, to add Na-TiA directly to Tank 8D2. If Na-TiA is used, it should be added only to the washed supernatant solution. Greater than $98 \%$ of the $\mathrm{Sr}, \mathrm{Pu}, \mathrm{Eu}$, and Am remain with the sludge after four washes. The distribution of $\mathrm{Np}$ is split between the supernatant $(\sim 40 \%)$ and the washed sludge $(\sim 60 \%)$.

\section{PRECIPITATION AND SORPTION PROCESSES}

The objective of the following section was t'o provide data using synthetic alkaline supernatant to support the precipitation process. A simplified schematic for this approach is shown in Figure 9. The precipitation process which uses $\mathrm{Na}-\mathrm{TPB}\left[\mathrm{Na}\left(\mathrm{C}_{6} \mathrm{H}_{5}\right)_{4} \mathrm{~B}\right]$ to selectively precipitate $\mathrm{Cs}^{+}, \mathrm{K}^{+}$and $\mathrm{Rb}^{+}$, and $\mathrm{Na}-\mathrm{TiA}$ $\left(\mathrm{Na}_{2} \mathrm{Ti}_{3} \mathrm{O}_{7}\right)$ to adsorb $\mathrm{Sr}^{2+}$ and $\mathrm{Pu}$ from the alkaline supernatant was developed at Savannah River Laboratory by Lee and Kilpatrick (1982) as an alternative to ion exchange. The attractive features of the process include its ability to provide high DFs for CS $\left(\sim 10^{4}\right)$ and $\mathrm{Sr}(200)$ from alkaline supernatant in a single batch contact. The process has been demonstrated in a full-scale test at SRP in 1983 .

Laboratory-scale experiments were conducted to study the performance of the Na-TPB precipitation process for recovery of $\mathrm{CS}$, and the Na-TiA precipitation process for recovery of $\mathrm{Sr}$ and $\mathrm{Pu}$ from simulated West Valley alkaline supernatant. The effects of the following process variables were examined: temperature $\left(25\right.$ and $\left.50^{\circ} \mathrm{C}\right), \mathrm{pH}(10.4$ and 13.7$)$, contact time (1 to 14 days), and quantity of precipitant chemical added. The experimental procedure is given in Appendix $C$.

The Na-TiA process showed enhanced recovery of $\mathrm{Sr}$ and $\mathrm{Pu}$ at a $\mathrm{pH}$ of 13.7 compared to 10.4 , and a temperature of $50^{\circ} \mathrm{C}$ compared to $25^{\circ} \mathrm{C}$. Recovery of $\mathrm{Sr}$ 


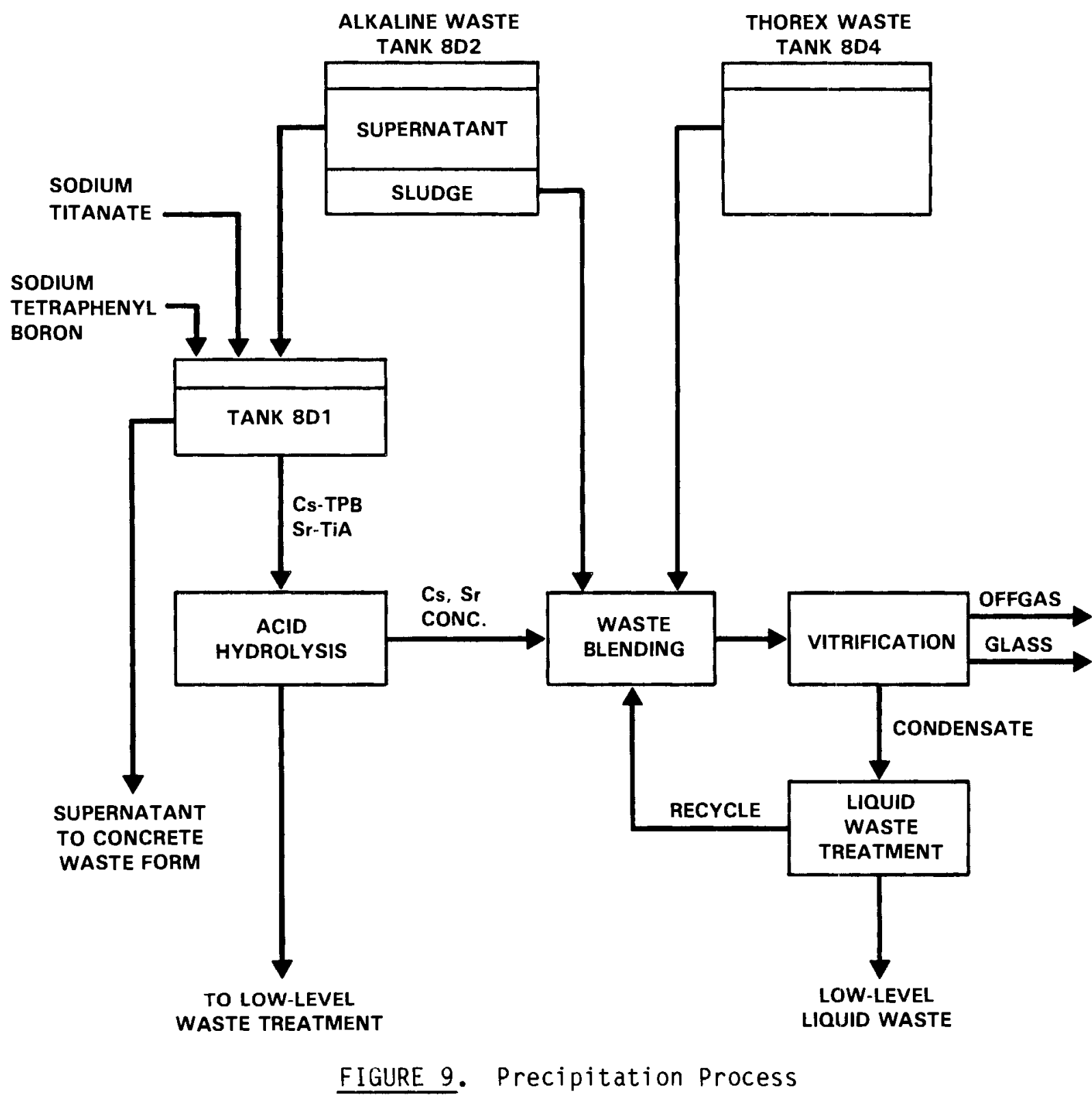

was independent of $\mathrm{Sr}$ concentration, indicating that $\mathrm{Sr}$ concentration is not a controlling factor. The Na-TiA precipitation process reached equilibrium with respect to recovery of $\mathrm{Sr}$ and $\mathrm{Pu}$ within 2 days. The performance of the Na-TiA recovery process improved with increasing concentrations of $\mathrm{Na}-\mathrm{TiA}$; however, the relative decontamination performance of the Na-TiA process decreased with increasing additions of $\mathrm{Na}-\mathrm{TiA}$. The Na-TiA recovery process is not selective for $\mathrm{Sr}$ or Pu. 
Cesium Precipitation Using Na-TPB

The following test parameters were examined for the Cs precipitation process:

- mole ratio $\mathrm{Na}-\mathrm{TPB} / \mathrm{Cs}+\mathrm{K}+\mathrm{Rb}(0.007$ to 2.3$)$

- $\mathrm{pH}(\sim 10$ and $\sim 13)$

- contact time (1 to 14 days)

- temperature $\left(25\right.$ and $\left.50^{\circ} \mathrm{C}\right)$

- Na concentration in the alkaline supernatant (3 to 6M).

The experimental results for recovery of $C s$ from the alkaline supernatant using Na-TPB are summarized in Tables 18 and 19 and are shown graphically in Figures 10 and 11 .

TABLE 18. Precipitation of Cesium Using Na-TPB $(a)$

\begin{tabular}{|c|c|c|c|c|}
\hline \multirow{2}{*}{$\begin{array}{l}\text { Na-TPB/Cs+K+Rb, } \\
\text { Mole Ratio } \\
\end{array}$} & \multicolumn{2}{|c|}{$\begin{array}{l}\text { Fraction Cesium in } \\
\text { Solution, } \mathrm{C} / \mathrm{Co} \\
\end{array}$} & \multicolumn{2}{|c|}{$\begin{array}{c}\text { Final } \mathrm{Na}^{+} \\
\text {Concentration, } \mathrm{M}\end{array}$} \\
\hline & $\mathrm{pH} \quad 12.8$ & $\mathrm{pH} 10.0$ & $\mathrm{pH} 12.8$ & $\mathrm{pH} 10.0$ \\
\hline $7.0 \mathrm{E}-3$ & $9.9 E-1$ & $9.6 \mathrm{E}-1$ & 6.8 & 6.6 \\
\hline $1.4 \mathrm{E}-2$ & $9.1 \mathrm{E}-1$ & $9.1 E-1$ & 6.8 & 6.6 \\
\hline $2.1 \quad E-2$ & $8.9 E-1$ & $8.7 \mathrm{E}-1$ & 6.8 & 6.6 \\
\hline $7.0 \mathrm{E}-2$ & $5.6 \mathrm{E}-1$ & $4.7 E-1$ & 5.7 & 5.4 \\
\hline $1.1 \mathrm{E}-1$ & $4.8 \mathrm{E}-1$ & $3.2 \mathrm{E}-1$ & 5.7 & 5.4 \\
\hline $1.4 \mathrm{E}-1$ & $3.0 \mathrm{E}-1$ & $3.1 \mathrm{E}-1$ & 5.7 & 5.4 \\
\hline $1.7 \mathrm{E}-1$ & $2.8 E-1$ & $2.8 E-1$ & 5.7 & 5.4 \\
\hline $4.6 \mathrm{E}-1$ & $3.0 \mathrm{E}-1$ & $2.6 \mathrm{E}-1$ & 5.8 & 5.6 \\
\hline $6.8 E-1$ & $1.3 \mathrm{E}-1$ & $1.1 \mathrm{E}-1$ & 5.8 & 5.6 \\
\hline $9.1 \mathrm{E}-1$ & $8.7 \quad E-2$ & $5.4 \quad E-2$ & 5.8 & 5.6 \\
\hline $1.1 E+0$ & $2.8 E-2$ & $1.3 \mathrm{E}-2$ & 5.8 & 5.6 \\
\hline $1.7 E+0$ & $8.5 E-5$ & $9.0 \quad E-5$ & 5.0 & 4.8 \\
\hline $2.3 E+0$ & $6.8 E-5$ & $1.0 \mathrm{E}-4$ & 5.0 & 4.8 \\
\hline
\end{tabular}

(a) Feed: $\sim 7 \mathrm{M} \mathrm{Na}{ }^{+} ; 1.1 \times 10^{-3} \mathrm{Cs}^{+} ; 0.069 \mathrm{M} \mathrm{K} \mathrm{K}^{+} ; 1 \times 10^{-4} \underline{\mathrm{M} \mathrm{Rb}}{ }^{+}$. Contact Time: 16 to 24 hours.

Temperature: $\sim 25^{\circ} \mathrm{C}$. 
TABLE 19. Removal of Cesium from Alkaline Supernatant Using Na-JPB

$\mathrm{Na}-\mathrm{TPB} /$

Cs+K+Rb, Final $\mathrm{Na}^{+}$Temp.,

Mole Ratio

$7.0 \mathrm{E}-1$

Conc., M

$7.0 \mathrm{E}-1$

4

${ }^{\circ} \mathrm{C}$

$1.0 \mathrm{E}+0$

$1.0 \mathrm{E}+0$

$1.1 \mathrm{E}+0$

$1.1 \mathrm{E}+0$

25

$\frac{1 \text { Day }}{9.3 \mathrm{E}-2}$

$\frac{3 \text { Days }}{8.8 \mathrm{E}-2}$

Solution, $\mathrm{C} / \mathrm{Co}$

$1.4 \mathrm{E}+0$

4

50

$1.1 \mathrm{E}-1$

1.1 E-1

$8.7 \mathrm{E}-2$

$8.4 \mathrm{E}-2$

$1.4 \mathrm{E}+0$

4

25

$2.4 E-3$

$2.3 \mathrm{E}-2$

1.1. E-1

$1.1 \mathrm{E}-2$

$1.8 E+0$

4

50

$1.4 \mathrm{E}-2$

$2.5 \mathrm{E}-2$

$2.0 \mathrm{E}-2$

$2.0 \mathrm{E}-2$

$1.8 \mathrm{E}+0$

4

25

$4.0 \mathrm{E}-3 \quad 8.0 \mathrm{E}-3$

$2.3 \mathrm{E}-2$

$2.3 \mathrm{E}-2$

$1.1 E+0$

4

50

$2.0 \mathrm{E}-3 \quad 7.0 \mathrm{E}-3$

$6.0 \mathrm{E}-3$

$5.0 \mathrm{E}-3$

$1.1 E+0$

4

25

$2.0 \mathrm{E}-3$

7.0 E-6

$5.0 E-3$

4.0 E-3

$1.1 E+0$

4

50

$2.0 \mathrm{E}-5 \quad 4.0 \mathrm{E}-5$

$2.0 E-5$

$3.0 \mathrm{E}-4$

$1.1 \mathrm{E}+0$

4

25

$6.0 \mathrm{E}-5$

$\sim 0$

$2.0 \mathrm{E}-5$

$2.0 E-4$

50

3.0 E-5 4.0 E-5

$\sim$

3.0 E-4

4

25

$2.3 \mathrm{E}-1$

$1.9 \mathrm{E}-1$

$-0$

$2.0 E-4$

6

50

$1.8 \mathrm{E}-1$

$1.6 \mathrm{E}-1$

$1.5 \mathrm{E}-1$

$1.3 \mathrm{E}-1$

6

25

$5.2 \mathrm{E}-2$

$3.3 \mathrm{E}-2$

1.4 E-1

1.3 E-1

5

50

$4.9 \mathrm{E}-2$

$2.9 \mathrm{E}-2$

2.4. E-2

$2.0 \mathrm{E}-2$

$1.1 \mathrm{E}+0$

25

$1.0 \mathrm{E}-2$

$6.0 \mathrm{E}-3$

$2.3 E-2$

2.D E-2

$1.1 \mathrm{E}+0$

50

$8.0 \mathrm{E}-3$

$2.0 \mathrm{E}-4$

$6.0 \mathrm{E}-3$

$3.0 \mathrm{E}-3$

$1.1 \mathrm{E}+0$

25

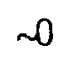

$2.0 \mathrm{E}-4$

$7.0 \mathrm{E}-5$

7.D E-4

$1.1 \mathrm{E}+0$

3

50

$1.5 \mathrm{E}-2 \quad 4.0 \mathrm{E}-3$

$\rightarrow 0$

$7.0 \mathrm{E}-4$

8. 1 E-5

$5.0 \mathrm{E}-4$

(a) Feed: $7 \underline{\mathrm{M} \mathrm{Na}}{ }^{+} ; 0.001 \underline{\mathrm{M}} \mathrm{Cs}^{+} ; 0.16 \underline{\mathrm{M} \mathrm{K}}{ }^{+} ; 1 \times 10^{-4} \underline{\mathrm{M}} \mathrm{Rb}^{+} ; \mathrm{pH} 10.4$.

Cs recovery using $\mathrm{Na}-\mathrm{TPB}$ is dramatically improved when the mole ratio $\mathrm{Na}-\mathrm{TPB}$ to $\mathrm{C} S+\mathrm{K}+\mathrm{Rb}$ is $>1$. This indicates strong competition between the cations ( $C S, K$, and $R D$ ) in the precipitation reaction. Once the cation concentration is equivalent to the Na-TPB concentration, the recovery of $\mathrm{CS}$ by $\mathrm{Na}-\mathrm{TPB}$ is very efficient. To achieve a CS DF of $>10^{4}$, this ratio must be at least 1.4 ( $\mathrm{Na}-\mathrm{TPB}$ required was estimated to be $2 \times 10^{5} \mathrm{~kg}$ for Tank 802 ). However, at mole ratios $>1$, the soluble Na-TPB concentration increases in the supernatant. This situation may pose difficulties in supernatant disposal because soluble Na-TPB could complex radionuclides, making them more leachable from the LLW form. Also, the 


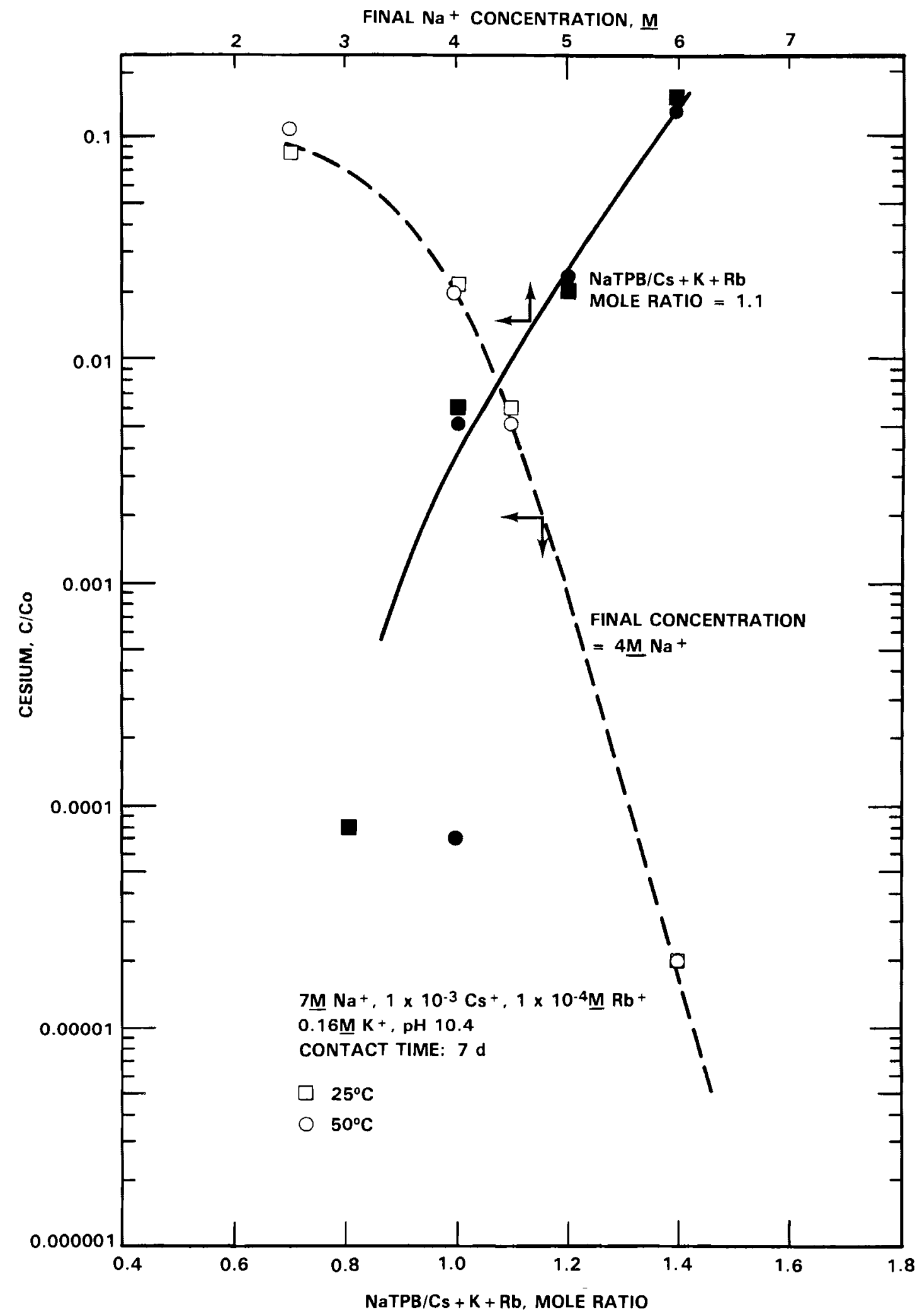

FIGURE 10. Cesium Precipitation from Simulated West Valley Alkaline Supernatant as a Function of $\mathrm{Na}-\mathrm{TPB} / \mathrm{Cs}_{\mathrm{S}} \mathrm{K}+\mathrm{Rb}$ Mole Ratio, $4 \mathrm{M} \mathrm{Na}^{+}$ 


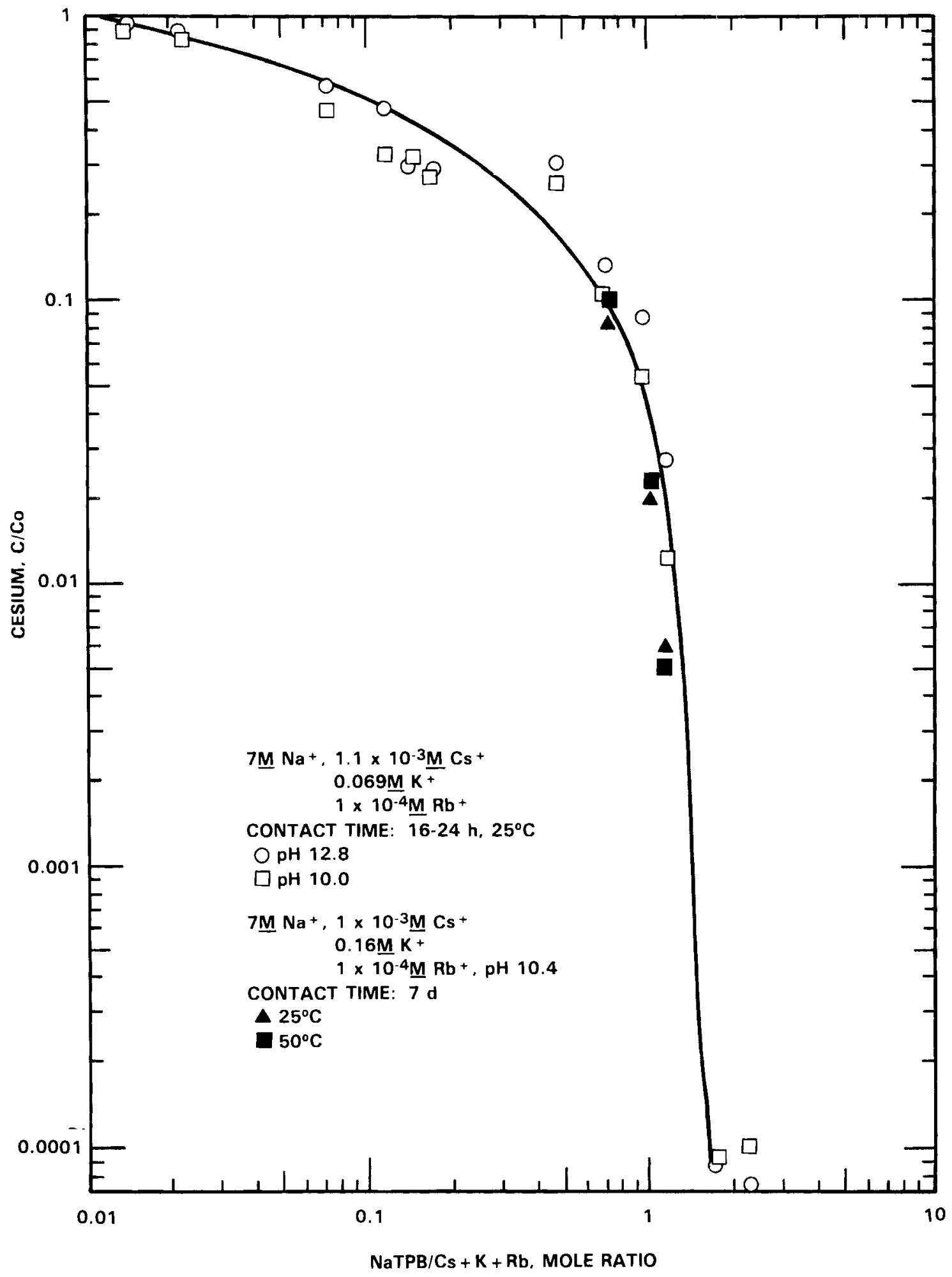

FIGURE 11. Cesium Precipitation from Simulated West Valley Alkaline Supernatant as a Function of $\mathrm{Na}-\mathrm{TPB} / \mathrm{Cs}+\mathrm{K}+\mathrm{Rb}$ Mole Ratio, 7M $\mathrm{Na}^{+}$ 
soluble Na-TPB may interfere with Tc recovery by organic anion exchange because the TPB anion will use up resin capacity.

The recovery of Cs from the alkaline supernatant is independent of solution $\mathrm{pH}$ in the range of 10.4 to 12.8 , as shown in Figure 10 and Table 18 .

Recovery of Cs from alkaline supernatant with $\mathrm{Na}$-TPB is dependent on contact time at times $<7$ days as shown in Table 19. The recovery fractions were erratic with $<7$ days of contact time. After 7 days, the system became stable with a consistent recovery fraction for Cs.

The recovery of $\mathrm{Cs}$ from the alkaline waste supernatant using $\mathrm{Na}-\mathrm{TPB}$ is essentially temperature independent in the range 25 to $50^{\circ} \mathrm{C}$ as shown in Table 19 and Figures 10 and 11.

Both the Na-TPB and the Na-TiA should be added to the supernatant after it has been separated from the sludge. The Na-TPB precipitate has a gelatinous consistency and floats on the top of the supernatant when sludge is present. Adding the Na-TPB to the supernatant/sludge mixture will complicate the sludge washing operation and treatment of the organic precipitate prior to vitrification of the waste. Adding the Na-TPB mixture to a separate supernatant phase simplifies processing operations.

Strontium and Plutonium Adsorption Using Na-TiA

The following test parameters were examined for the Sr/Pu recovery process:

- mole ratio $\mathrm{Na}-\mathrm{TiA} / \mathrm{Sr}(740$ to 6100$)$

- $\mathrm{pH}$ ( 10 and $\sim 13)$

- contact time (1 to 14 days)

- temperature $\left(25\right.$ and $\left.50^{\circ} \mathrm{C}\right)$.

Initial experiments involved recovery of $\mathrm{Sr}$ and $\mathrm{Pu}$ with $\mathrm{Na}-\mathrm{TiA}$ in which the stock supernatants were prepared by neutralization of simulated acidic PUREX waste. The experimental results are summarized in Table 20 and Figure 12 . 
TABLE 20. Removal of Strontium from Alkaline Supernatant Using Na-TiA Slurry

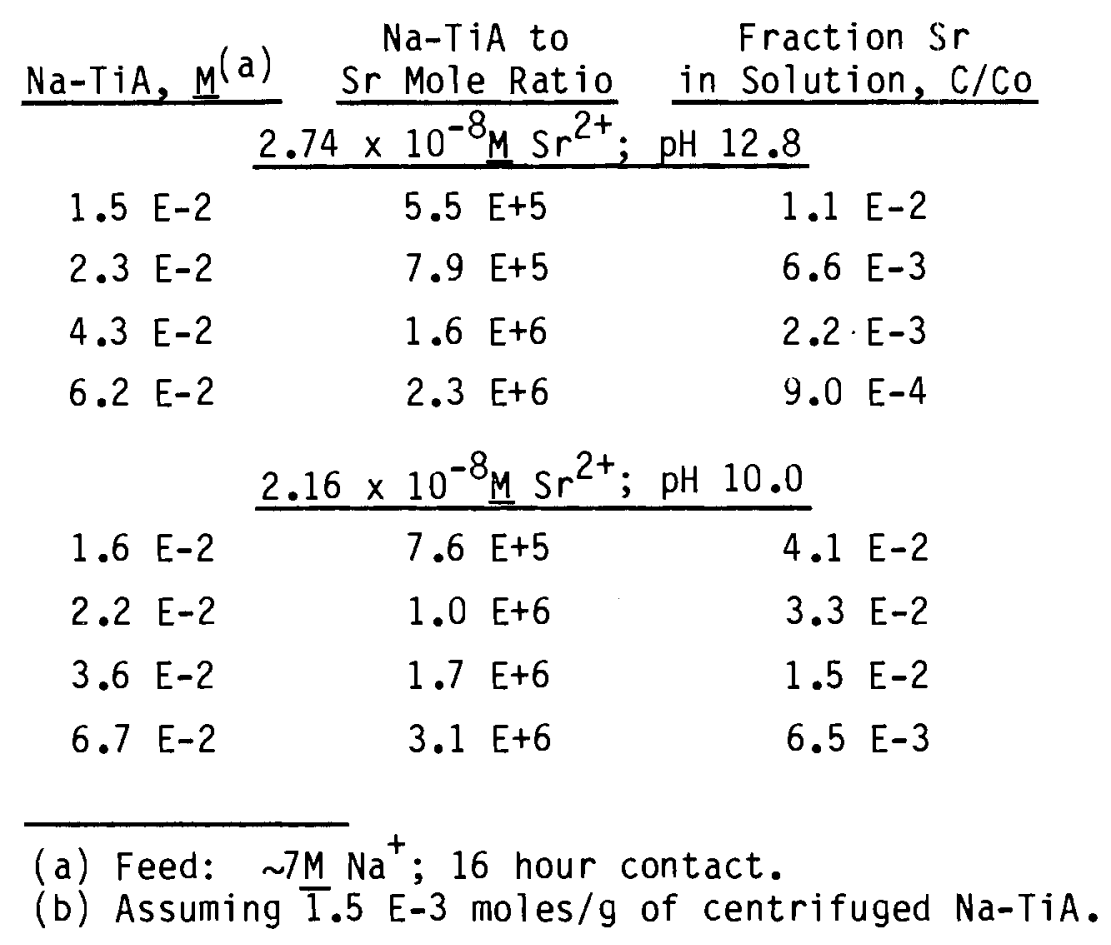

$\begin{array}{llll} & & 2.16 \times 10^{-8} \mathrm{M} \mathrm{Sr}{ }^{2+} ; \mathrm{pH} 10.0 & \\ 1.6 \mathrm{E}-2 & 7.6 \mathrm{E}+5 & 4.1 \mathrm{E}-2 \\ 2.2 \mathrm{E}-2 & 1.0 \mathrm{E}+6 & 3.3 \mathrm{E}-2 \\ 3.6 \mathrm{E}-2 & 1.7 \mathrm{E}+6 & 1.5 \mathrm{E}-2 \\ 6.7 \mathrm{E}-2 & 3.1 \mathrm{E}+6 & 6.5 \mathrm{E}-3\end{array}$

Additional experiments were then completed to determine the removal of $\mathrm{Pu}$ and $\mathrm{Sr}$ from alkaline supernatant as a function of $\mathrm{pH}$, temperature, and contact time. These results are shown in Figures 12 and 13 and Table 21.

The recoveries of $\mathrm{Sr}$ and $\mathrm{Pu}$ from the supernatant were dependent on solution $\mathrm{pH}$ in the range 10 to 14 . Both the $\mathrm{Sr}$ and $\mathrm{Pu}$ systems showed greater recovery with the use of $\mathrm{Na}-\mathrm{TiA}$ at higher $\mathrm{pH}$ levels; Sr recovery improved by a factor of 10 as the $\mathrm{pH}$ is raised from 10.4 to 13.7, and Pu recovery improved by a factor up to 3 (Figure 13) when the $\mathrm{pH}$ is increased from 10.4 to 13.7. This improvement in recovery for $\mathrm{Sr}$ and $\mathrm{Pu}$ with increasing $\mathrm{pH}$ is not understood. Figure 12 shows that for two concentrations of $\mathrm{Sr}$ in the alkaline waste $(1.3 \mathrm{x}$ $10^{-5} \underline{M}$ and $\left.2.7 \times 10^{-8} \underline{M}\right)$, there was no increase in sr recovery at a given $\mathrm{pH}$ level. This suggests that Na-TiA is not specific for Sr. Other ions in solution that may be controlling have not been identified.

Strontium recovery using $\mathrm{Na}-\mathrm{TiA}$ is independent of temperature (Table 21 and Figure 12), but the recovery of $\mathrm{Pu}$ by $\mathrm{Na}-\mathrm{TiA}$ is sensitive to temperature 


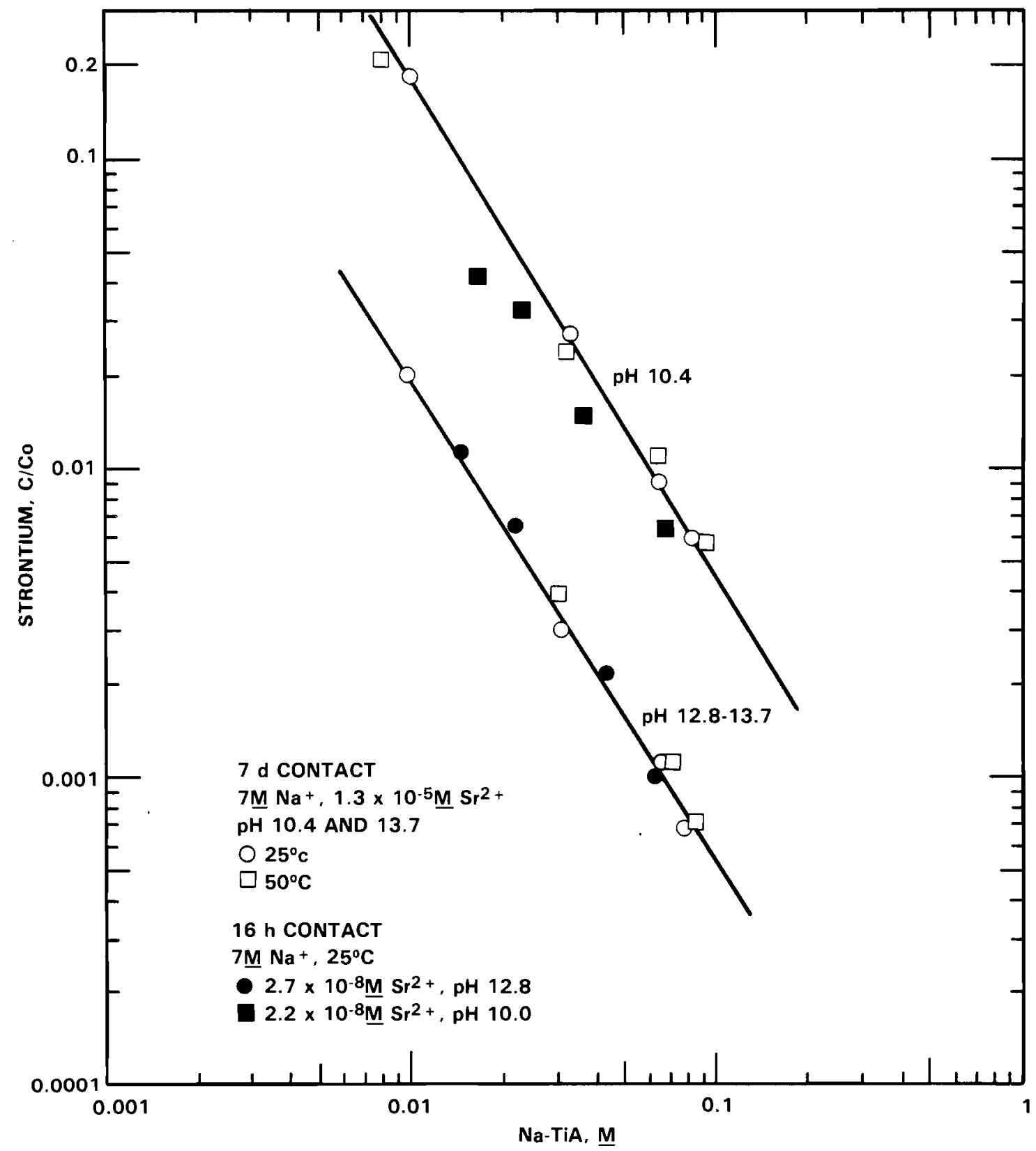

FIGURE 12. Adsorption of Strontium from Simulated West Valley Alkaline Supernatant Using $\mathrm{Na}-\mathrm{TiA}$ 


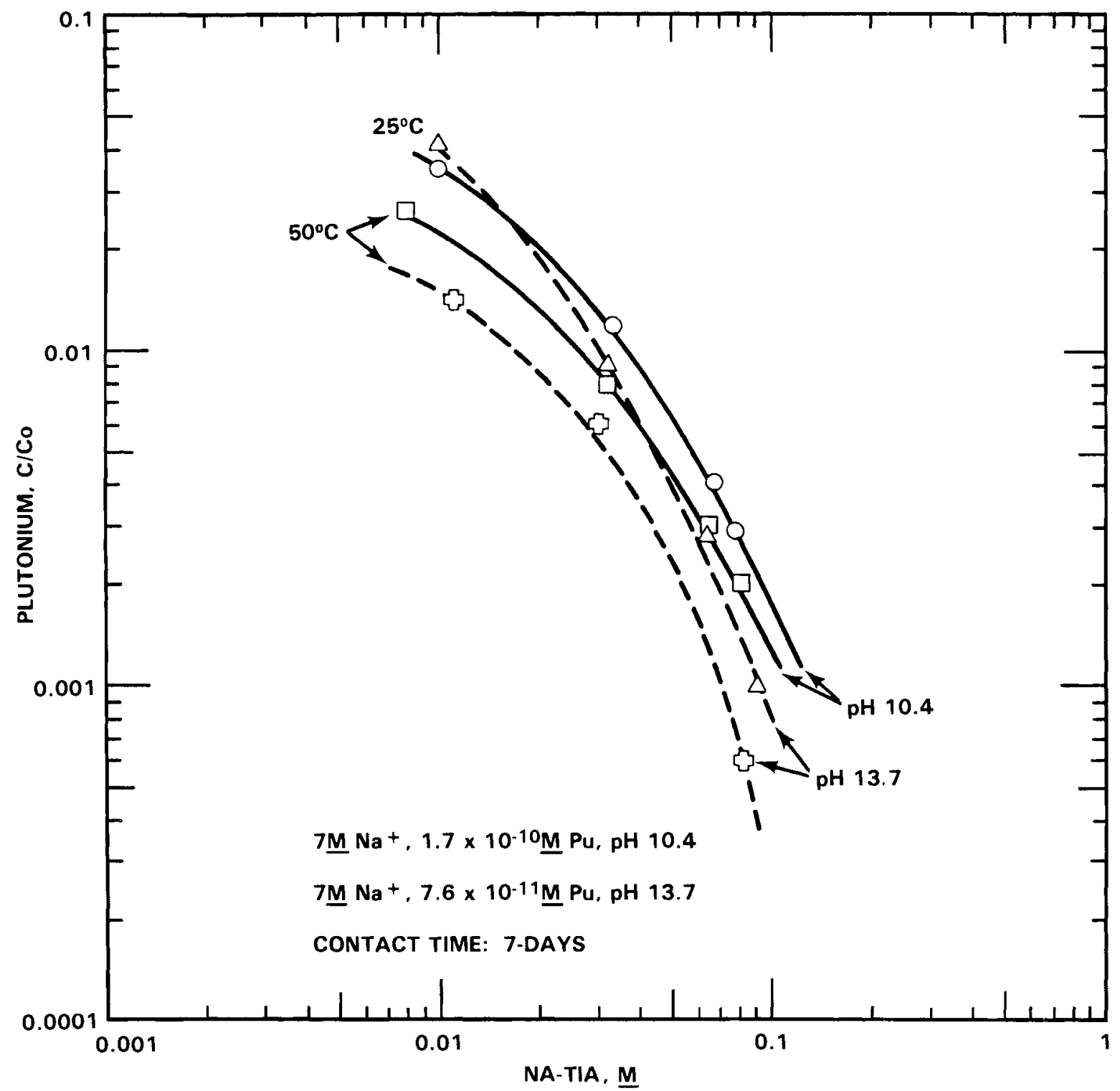

FIGURE 13. Adsorption of Plutonium from Simulated West Valley Alkaline Supernatant Using $\mathrm{Na}-\mathrm{TiA}$

(Table 21, Figure 13). At concentrations between $1 \times 10^{-2} \underline{M}$ and $8 \times 10^{-2} \underline{M}$ of $\mathrm{Na}-\mathrm{TiA}, 1.5$ to 3 times more $\mathrm{Pu}$ is removed at a temperature of $50^{\circ} \mathrm{C}$ compared to $25^{\circ} \mathrm{C}$.

Strontium and Pu recovery is dependent upon contact time. As shown in Table 21, the recovery of Sr and Pu improved with contact times up to 2 days. At this time the system had stabilized at equilibrium. In general, Sr recovery

42 
TABLE 21. Removal of Plutonium and Strontium from Alkaline Supernatant Using Na-TiA as a Function of $\mathrm{pH}$ and Temperature

Feed: $\sim 7 \mathrm{M} \mathrm{Na}{ }^{+} ; 1.3 \times 10^{-5} \mathrm{M} \mathrm{Sr}{ }^{2+} ; \mathrm{pH} 10.4 ; 1.7 \times 10^{-10} \underline{M} \mathrm{Pu}$; supernatant prepared by chemical mixing approach.

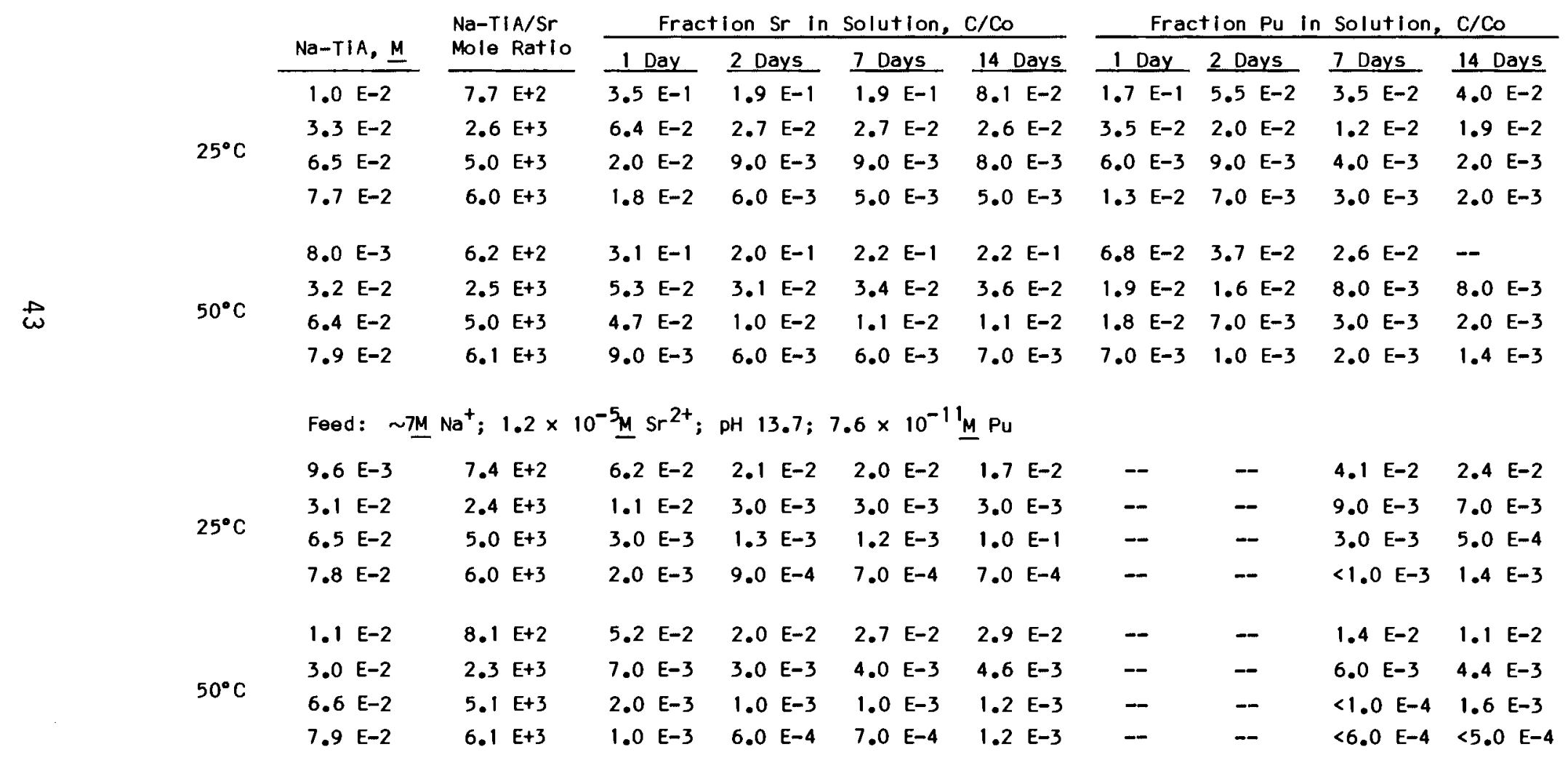


improved by a factor of 1.3 to 2 after 2 days of contact; the Pu recovery improved by a factor of $\sim 2$ after 2 days of contact.

Strontium recovery improved with increased additions of $\mathrm{Na}-\mathrm{TiA}$. However, the relative rate of recovery decreased. For example, at a $\mathrm{pH}=10.4,0.01 \mathrm{M}$ $\mathrm{Na}-\mathrm{TiA}$ removed $82 \%$ of $\mathrm{Sr}$ in solution. Doubling the Na-TiA concentration increased the decontamination performance only by an additional $12 \%$. Absolute and relative rates of recovery for $\mathrm{Pu}$ also showed the same behavior, indicating that $\mathrm{Na}-\mathrm{TiA}$ is not specific for $\mathrm{Sr}$ or $\mathrm{Pu}$, and that competing ions (possibly $\mathrm{Cr}$, $\mathrm{Fe}$, or $\mathrm{Ni}$ ) have a strong influence in the system.

To achieve DFs of 225 for $\mathrm{Sr}$ and $>6$ for $\mathrm{Pu}$, the mole ratio of $\mathrm{Na}-\mathrm{TiA}$ to $\mathrm{Sr}$ must be 10,000 or greater at a pH of 10.4 and a temperature of $25^{\circ} \mathrm{C}$. The mass of $\mathrm{Na}-\mathrm{TiA}$ required for this DF was estimated to be $1.2 \times 10^{5} \mathrm{~kg}$ for West Valley Tank 8D2. No adverse effects were noted when combining $\mathrm{Na-TPB}$ and $\mathrm{Na}-\mathrm{TiA}$ in the experimental studies. However, as mentioned previously, the precipitant chemicals should be added to supernatant separated from the sludge.

Based on the above laboratory data and minimum process requirements, conditions that should assure optimum performance for a precipitation system are shown in Table 22.

\section{ION-EXCHANGE PROCESS}

Laboratory-scale experiments were conducted to study the performance of organic and inorganic ion exchangers for the decontamination of West Valley alkaline supernatant from Sr, Cs, and Pu; and the recovery of Tc by the use of an organic anion exchange resin. Simulated supernatant prepared by direct chemical mixing (see Appendix A), was used for these experiments. Batch distribution ratios $\left(R_{d}\right)$ were measured to determine the ability of a select group of organic and inorganic exchangers to remove the radionuclides of interest from solution. The results for the batch sorption tests showed that the oryanic ion-exchange process (with Duolite CS-100 and Amberlite IRC-718) was viable for ion-exchange column testing, and that a zeolite inorganic exchanger should also be investigated. 
TABLE 22. Optimum Conditions for a Precipitation System

$\begin{array}{ll}\begin{array}{c}\text { Process } \\ \text { Parameters }\end{array} & \frac{\text { Optimum Conditions }}{25 \text { to } 50^{\circ} \mathrm{C}} \\ \mathrm{pH} & 10.4 \text { to } 13\end{array}$

Precipitation Higher temperatures enhance $\mathrm{Pu}$
recovery by $\mathrm{Na}-\mathrm{TiA}$.

Increased $\mathrm{pH}$ enhances $\mathrm{Sr} / \mathrm{Pu}$ recovery at a constant $\mathrm{Na}-\mathrm{TiA}$ concentration.

Contact time 7 days minimum

Equilibrium is readily achieved in well-mixed laboratory-scale system. Engineering-scale system has not been evaluated.

Mass of $\mathrm{Na}-\mathrm{TPB}$ Coverage: 1.4 moles required for $\mathrm{Na}-\mathrm{TPB} / \mathrm{mole} \mathrm{Cs}+\mathrm{K}+\mathrm{Rb}$

About $2 \times 10^{5} \mathrm{~kg} \mathrm{Na}-\mathrm{TPB}$ a re reguired for Cs DF of $10^{4}, \sim 1.6 \times$ Tank 802 $10^{5} \mathrm{~kg} \mathrm{Na} a_{5}$ TPB for CS DF of 130 , and $<0.5 \times 10^{5} \mathrm{~kg} \mathrm{Na-TPB}$ for CS DF of 1.3 .

Mass of Na-TiA Coverage: 10,000 moles required for $\mathrm{Na}-\mathrm{TiA} / \mathrm{mole} \mathrm{Sr}$

Tank 8D2

Precipitant chemical addition
$\mathrm{Na}-\mathrm{TPB}$ and $\mathrm{Na}-\mathrm{TiA}$ addition to supernatant separated from sludge
About $1.5 \times 10^{5} \mathrm{~kg}$ of $\mathrm{Na}-\mathrm{TiA}$ are required based on $0.1 \mathrm{M} \mathrm{Na-T} \mathrm{TA}$ at $\mathrm{pH}=10.4$. This mass of $\mathrm{Na}-\mathrm{TiA}$ wi 11 increase glass mass by a factor of up to 7 .

Na-TPB interferes with sludge washing. A large mass of Na-TiA will be required to achieve equilibrium with total $\mathrm{Sr}$ in tank if sludge is present.

Precipitation will not remove TC from solution.

An experimental ion-exchange system consisting of a $1.8-\mathrm{cm}-\mathrm{dia}$ ID glass ion-exchange column containing $100 \mathrm{~mL}^{3}$ of exchanger was used to provide reproducible tests. Experiments were completed to examine the effects of temperature, $\mathrm{pH}$, flow rate, and $\mathrm{Na} / \mathrm{Cs}$ mole ratio in the feed. 


\section{Batch Sorption}

To select ion-exchange materials for the recovery of $\mathrm{Cs}, \mathrm{Sr}$, and $\mathrm{Pu}$ from alkaline supernatant, a batch sorption screening test was completed. The laboratory test, described in Appendix $D$, provides a rapid and cost-effective method for comparing the selectivity of a wide variety of materials for specific radionuclides. When this work was initiated (October 1982), the need for radionuclide decontamination had not been completely assessed because the actual composition of the West Valley alkaline supernatant had not been determined. Therefore, a wide variety of candidate radionuclides were included in this initial study.

Batch ion-exchange experiments involved contacting a sample of supernatant containing the radionuclide under investigation with a small weighed sample of ion-exchange material. Contact was maintained 7 days at room temperature. The alkaline supernatant was adjusted to $\mathrm{pH} 10$ or 13 . Because only one contact time was tested, radionuclides that slowly equilibrate with the exchange material were not identified. Additional tests as a function of time and temperature would be required to identify kinetic and equilibrium problems. The batch test was used to rank the candidate exchangers, but did not eliminate the need to conduct flow-through ion-exchange column testing on selected exchangers.

The $R_{d}$ values for the radionuclides are shown in Table: 23 for each exchanger type. A general description of each exchanger is given in the Experimental section of this report.

A comparison of $R_{d}$ values for $C s$ at $\mathrm{pH} 10$ shows that $I E-95$ and AW-500 rank above CS-100. At a pH of 13, IE-95, AW-500, and CS-100 are equal. Strontium results show that the organic exchanger IRC-718 ranks above IE-95 and AW-500 at $\mathrm{pH} 10$, but that $\mathrm{AW}-500$ has a higher $\mathrm{R}_{\mathrm{d}}$ value at $\mathrm{pH}$ 13. Plutonium results at $\mathrm{pH}$ 10 show that IRC-718 and ARC-359 are superior to IE-95 or AW-500. Technetium is removed only by charcoal and a group of organic anion exchange resins. Neptunium, Eu, and Am show some exchange using AW-500, IE-95, CS-100, and $A R C-718$ at $\mathrm{pH}$ 10. Iodine is removed by the organic resins at both $\mathrm{pH} 10$ and 13. Ruthenium is removed only by charcoal. 
TABLE 23. Batch $R_{d}$ Values for Radionuclides for Different Exchanger Types

\begin{tabular}{|c|c|c|c|c|c|c|c|c|c|c|}
\hline Element & $\underline{p H}$ & $\begin{array}{c}\text { AW-500 \& IE-95 } \\
\text { (Average) } \\
\end{array}$ & CS- 100 & ARC-359 & IRC-718 & $A-51$ & $\begin{array}{c}\text { IRC-84 \& IRC-50S } \\
\text { (Average) }\end{array}$ & Charcoal & $\begin{array}{c}\text { Dowex }-1, \times 8 \\
\text { IRA-401 IRA-402 } \\
\text { (Average) } \\
\end{array}$ & IRA-458 \\
\hline $\mathrm{Cs}$ & 10 & 39 & 14 & 12 & 2 & $<1$ & $<1$ & $<1$ & -- & -- \\
\hline & 13 & 34 & 34 & 24 & 1.7 & $<1$ & $<1$ & $<1$ & -- & - \\
\hline & 13 & 1408 & $<1$ & $<1$ & 177 & 21 & -- & $<1$ & -- & - \\
\hline Pu & 10 & 19 & 284 & 108 & $<1$ & $<1$ & - & $<1$ & -- & -- \\
\hline Tc & 10 & $<1$ & $<1$ & $<1$ & $<1$ & $<1$ & -- & 67 & 223 & 138 \\
\hline \pm & 13 & 28 & $<1$ & 19 & $<1$ & $<1$ & -- & $<1$ & -- & -- \\
\hline 1 & 10 & 1 & 56 & 17 & 36 & 1.5 & -- & 4 & -- & -- \\
\hline & 13 & $\sim 2$ & 34 & 11 & 22 & $<1$ & -- & 3 & -- & -- \\
\hline $\mathrm{Eu}$ & 10 & 790 & 683 & 101 & 100 & 1.2 & -- & 3 & - & - \\
\hline & 13 & 9300 & 2760 & 132 & $<1$ & 892 & -- & 71 & -- & -- \\
\hline Ru & 10 & $<1$ & 8 & 5 & 10 & $<1$ & $<1$ & 386 & -- & - \\
\hline
\end{tabular}

(a) Not determined. 
The overall results for the batch sorption tests show that the organic ion-exchange resins CS-100 and IRC-718 and the IE-95 inorganic exchanger are viable candidates for the removal of $\mathrm{Cs}, \mathrm{Sr}$, and $\mathrm{Pu}$ from alkaline supernatant. Removal of Tc using any of the quaternary ammonium polystyrene anion resins such as Dowex $-1, x 8$ appears feasible.

Organic Ion Exchange

The objective of the following section is to provide data to support the organic resin ion exchange process using synthetic alkaline supernatant. A simplified schematic for this approach is shown in Figure 14. In the alkaline supernatant from Tank $8 D 2, C S$ is removed using a granular Duolite CS-100 organic ion exchanger, followed by an organic macroporous cation exchanger (Amberlite IRC-718) to remove Sr.

Duolite CS-100 performance for Cs was found to be dependent upon the resin particle size, temperature, and feed $\mathrm{pH}$. Higher Cs loadings were achieved at smaller resin size classifications. Cesium loadings improved by a factor of 1.3 as the feed temperature was lowered from 50 to $6^{\circ} \mathrm{C}$. When the alkaline supernatant feed $\mathrm{pH}$ was increased from 10.4 to 13.6 , the loading capacity increased by a factor of 3.3 at a $\mathrm{Cs}$ breakthrough of $0.5 \mathrm{C} / \mathrm{Co}$. At a feed $\mathrm{pH}$ of 13.8, the maximum $C S$ decontamination performance for CS-100 ion exchanger was determined to be 1560 . No Pu decontamination was found. Elution was achieved by passing $10 \mathrm{cV}$ of $0.1 \mathrm{M}$ formic acid $(\mathrm{HCOOH})$ upflow through the resin bed. The eluate consists of $\mathrm{Cs}$ and $\mathrm{Na}$ formate.

Amberlite IRC-718 performance for $\mathrm{Sr}$ was dependent upon feed $\mathrm{pH}$. Strontium DFs of 100 and 1000 were achieved after $10 \mathrm{cv}$ of feed were loaded downflow $(0.6 \mathrm{cv} / \mathrm{h})$ at alkaline supernatant $\mathrm{pH}$ values of 10.8 and 13.3 , respectively. After loading, the column was rinsed with water and eluted upflow with $5 \mathrm{cv}$ of $2 \mathrm{M} \mathrm{HCOOH}$.

\section{CS-100 Loading and Elution}

Experience with CS-100 has been limited to laboratory-scale loading and elution testing at SRP. Further experimentation with this resin was necessary to provide more complete characterization as it applied to the West valley alkaline supernatant. These results are shown below. 


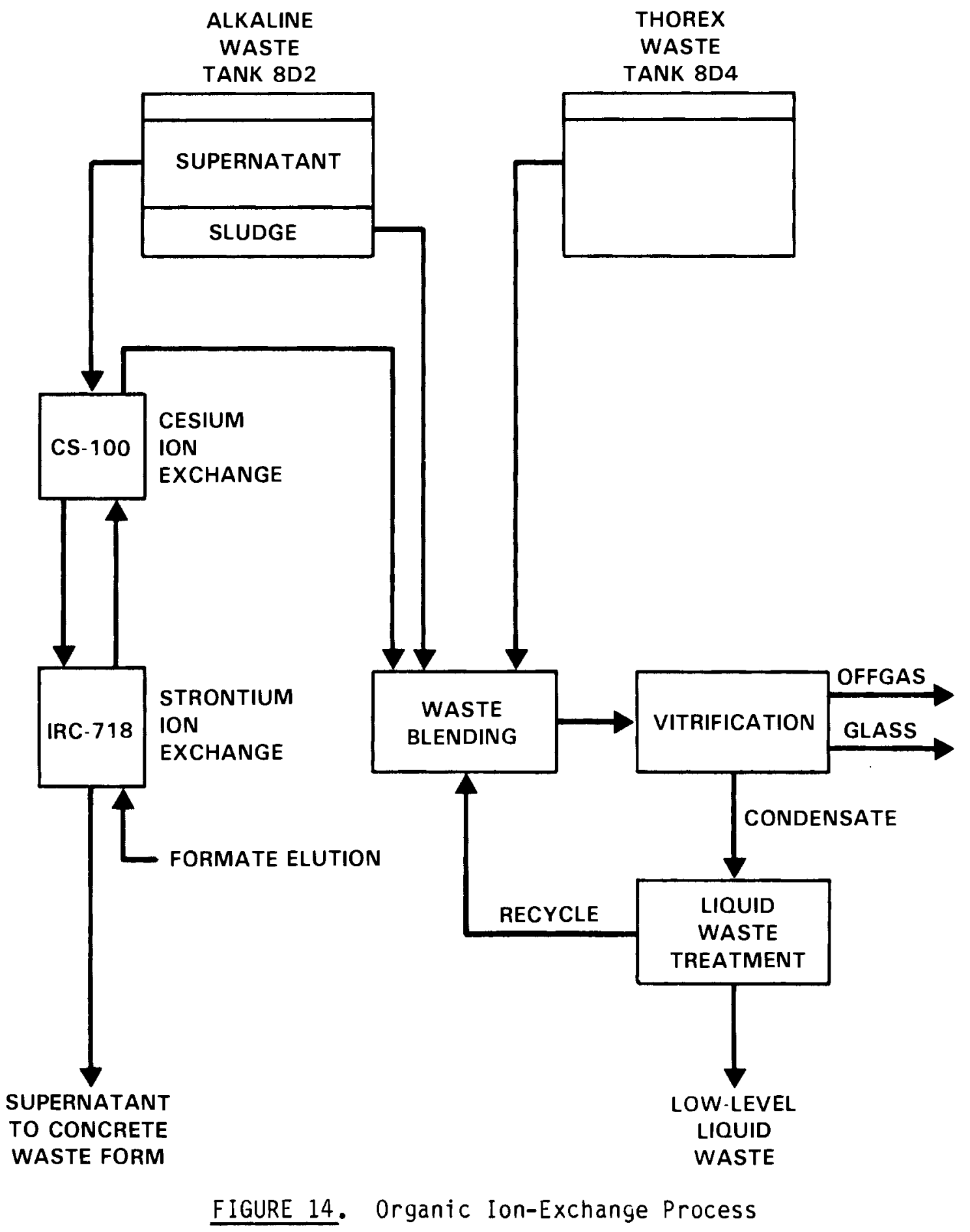


The CS-100 was found to be very particle-size dependent. The "asreceived" resin was sieved to determine its size (Table 2). Approximately $22 \mathrm{wt} \%$ was retained on 20 -mesh $(0.85 \mathrm{~mm})$ screen, and $75 \mathrm{wt} \%$ on 40 -mesh $(0.425$ $\mathrm{mm}$ ) screen. Figure 15 shows CS breakthrough curves for $\mathrm{pH} 13.6$ alkaline supernatant for 3 mesh sizes: as received, 60-mesh, and 80-mesh, with a 0.01 $\mathrm{C} / \mathrm{Co} \mathrm{Cs}$ breakthrough occurring at $2,4.7$, and $6.4 \mathrm{cv}$, respectively. The fine mesh resin was prepared by grinding the resin under water and sizing.

The CS-100 resin was very temperature dependent as shown in Figure 16 . Using 60-mesh resin, $\mathrm{pH} 13.6$ feed at $0.6 \mathrm{cv} / \mathrm{h}$, the $0.01 \mathrm{c} / \mathrm{Co}$ breakthrough for $\mathrm{Cs}$ at 50,25 , and $6^{\circ} \mathrm{C}$ was $2.1,5$, and $7.3 \mathrm{cv}$, respectively. The $\mathrm{Cs}^{+}$loading at $0.01 \mathrm{C} / \mathrm{Co}_{0}$ increased by a factor of 3.5 as the temperature decreased from 50 to $6^{\circ} \mathrm{C}$. Although the feed remained physically stable at $6{ }^{\circ} \mathrm{C}$, application may be difficult in a large-scale plant.

The capacity of $\mathrm{CS}-100$ to retain $\mathrm{Cs}^{+}$from $\mathrm{pH} 13.6$ alkaline supernatant (8.2 $\mathrm{M} \mathrm{Na}^{+}$) decreased with an increasing $\mathrm{Na} / \mathrm{Cs}$ mole ratio as shown in Figure 17 and Table 24. As the $\mathrm{Na} / \mathrm{Cs}$ mole ratio was increased by a factor of 100 , the number of $C V^{\prime} s$ of feed loaded increased by a factor of 2.3 at $0.01 \mathrm{C} / \mathrm{Co}$, and the mass of Cs loaded decreased by a factor of 43 .

The CS loading of CS-100 increased with increasing $\mathrm{pH}$ since the phenolic resins are more selective (Cs versus $\mathrm{Na}$ ) with increasing $\mathrm{pH}$. The West Valley waste would therefore require a $\mathrm{pH}$ adjustment from $\mathrm{pH} 10$ to 13.8 to take advantage of the increased capacity. When feed was prepared at $\mathrm{pH} 10.4$ rather than $\mathrm{pH}$ 13.6, and $\mathrm{Cs}$ breakthrough values obtained (Figures 16 and 18) for 60-mesh CS-100, a $0.01 \mathrm{C} / \mathrm{Co}$ breakthrough occurred at 0.5 and $4.7 \mathrm{cv}$, respectively.

Batch $R_{d}$ measurements for $S r$ and $P u$ (Table 23) using CS-100 gave values of 82 and 284, indicating that they should be retained on ion-exchange columns at alkaline supernatant pH values of 10.4. However, a CS-100 column test. (Figure 18) shows no retention, with a $0.5 \mathrm{C} / \mathrm{Co}$ breakthrough at $2 \mathrm{cv}$ for both $\mathrm{Sr}$ and $\mathrm{Pu}$.

Detailed elution and Na scrubbing studies were completed by Grant (1983) and Wallace and Ferguson (1980) using formic acid. Therefore, we completed 


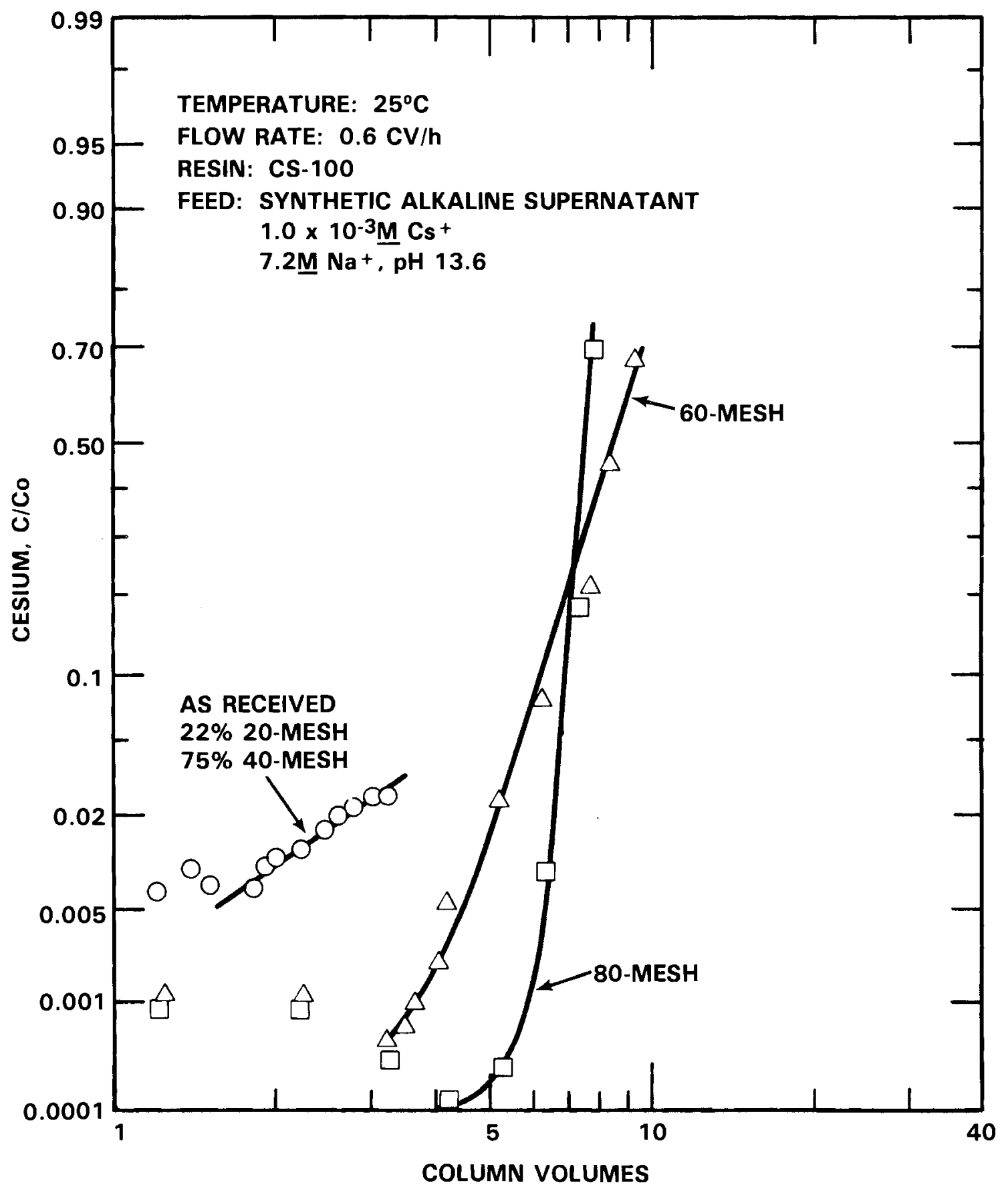

FIGURE 15. Cesium Breakthrough as a Function of Mesh Size for Organic Exchanger CS-100 


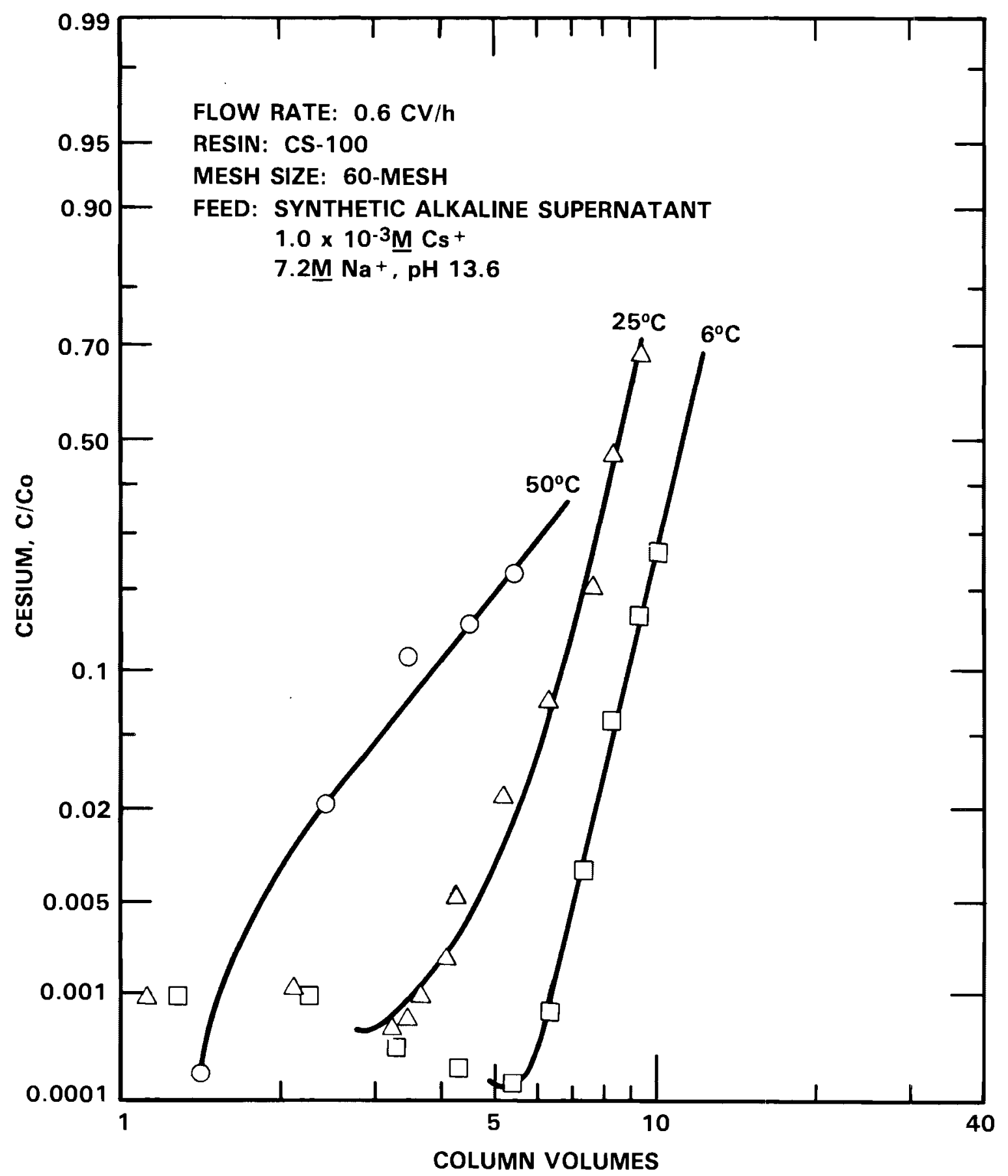

FIGURE 16. Cesium Breakthrough as a Function of Temperature for Organic Exchanger CS-100 


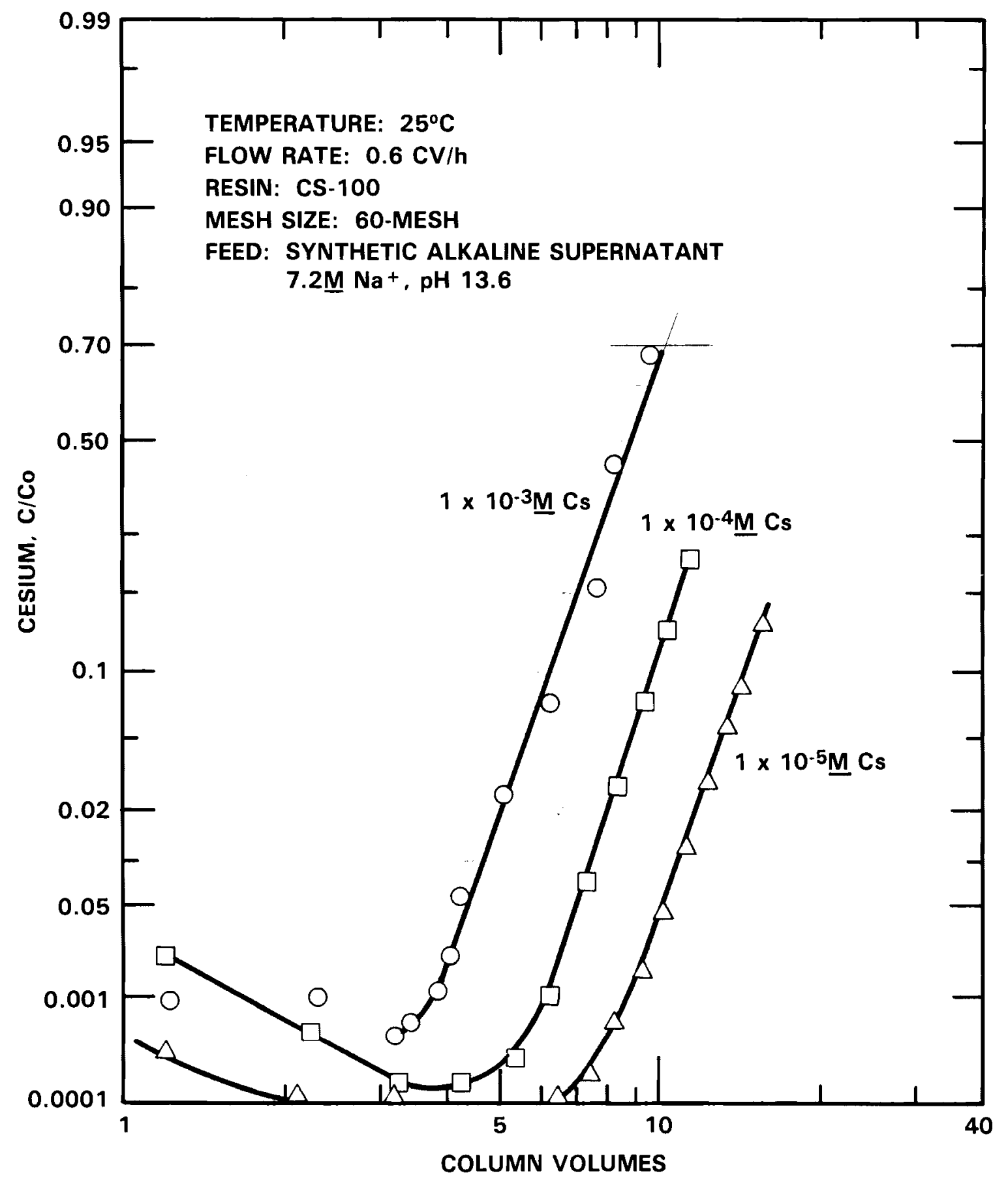

FIGURE 17. Cesium Breakthrough as a Function of the Influent Cesium Feed Concentration for Organic Exchanger CS-100 
TABLE 24. Cesium Loaded on $\mathrm{CS}-100$ as a Function of $\mathrm{Na} / \mathrm{Cs}$ Mole Ratio

\begin{tabular}{|c|c|c|}
\hline $\begin{array}{l}\mathrm{Na} / \mathrm{Cs} \text { Mole } \\
\text { Ratio } \\
\end{array}$ & $\begin{array}{c}\text { Column Volumes } \\
\text { at } 0.01 \mathrm{C} / \mathrm{Co} \\
\end{array}$ & $\begin{array}{l}\text { Moles CS Loaded/L } \\
\text { of CS-100 } \\
\end{array}$ \\
\hline $7.2 \mathrm{E}+3$ & 4.7 & $4.7 \mathrm{E}-3$ \\
\hline $7.2 E+4$ & 6.5 & $6.4 \mathrm{E}-4$ \\
\hline $7.2 E+5$ & 11 & $1.1 \mathrm{E}-5$ \\
\hline
\end{tabular}

only one loading, washing, and elution test. The alkaline supernatant containing ${ }^{137} \mathrm{Cs}$ and ${ }^{22} \mathrm{Na}$ tracers was adjusted to $\mathrm{pH} 13.8$ ( Na/Cs mole ratio = $6550)$, and $10 \mathrm{cv}$ of feed was loaded downflow at $0.6 \mathrm{cv} / \mathrm{h}$. A $0.01 \mathrm{c} /$ Co breakthrough was observed at $3.5 \mathrm{cv}$ (Figure 19). Approximately $18 \% \mathrm{Cs}$ and $94 \% \mathrm{Na}$ were found in the feed effluent. After washing the column downflow to displace the remaining feed, a $0.1 \mathrm{M} \mathrm{HCOOH}$ scrub solution (intended to preferentially remove $\mathrm{Na}^{+}$) was started upflow. After $7 \mathrm{cv}, 0.6 \% \mathrm{Na}^{+}$and $3 \% \mathrm{Cs}^{+}$of the initial feed was eluted. Unexpectedly, the next two column volumes of $0.1 \mathrm{M} \mathrm{HCOOH}$ removed $79 \% \mathrm{Cs}^{+}$and $2 \% \mathrm{Na}^{+}$(equivalent to $95 \% \mathrm{Cs}$ and $77 \% \mathrm{Na}$ initially loaded). The peak concentration of both the $\mathrm{Na}^{+}$and $\mathrm{Cs}^{+}$ions occurred simultaneously, indicating that the $0.1 \mathrm{M} \mathrm{HCOOH}$ does not selectively remove $\mathrm{Na}^{+}$ in preference to $\mathrm{Cs}^{+}$. The intended elution cycle solution, $2 \mathrm{M} \mathrm{HCOOH}$, was then introduced into the column, but was not required since the $0.1 \mathrm{M} \mathrm{HCOOH}$ had al ready efficiently removed the $\mathrm{Na}-\mathrm{Cs}$ product.

IRC-718 Loading and Elution

Amberlite IRC-718 is a chelating, macroreticular polystyrene divinylbenzene resin. It is highly selective for $\mathrm{Sr}$ and other polyvalent cations in highly alkaline systems such as Savannah River supernatant. Further experimentation with this resin was necessary to provide more complete characterization as it applied to the West Valley alkaline supernatant. These results are given below.

The macroreticular cation exchange resin, IRC-718, provided a $\mathrm{Sr}$ DF of $\sim 100$ and $\sim 1000$ after $10 \mathrm{cv}$ of feed were loaded downflow $(0.6 \mathrm{cv} / \mathrm{h})$ at alkaline supernatant $\mathrm{pH}$ values of 10.8 and 13.3 , respectively (Figures 20 and 21 ). No significant $\mathrm{Pu}$ decontamination was observed. 


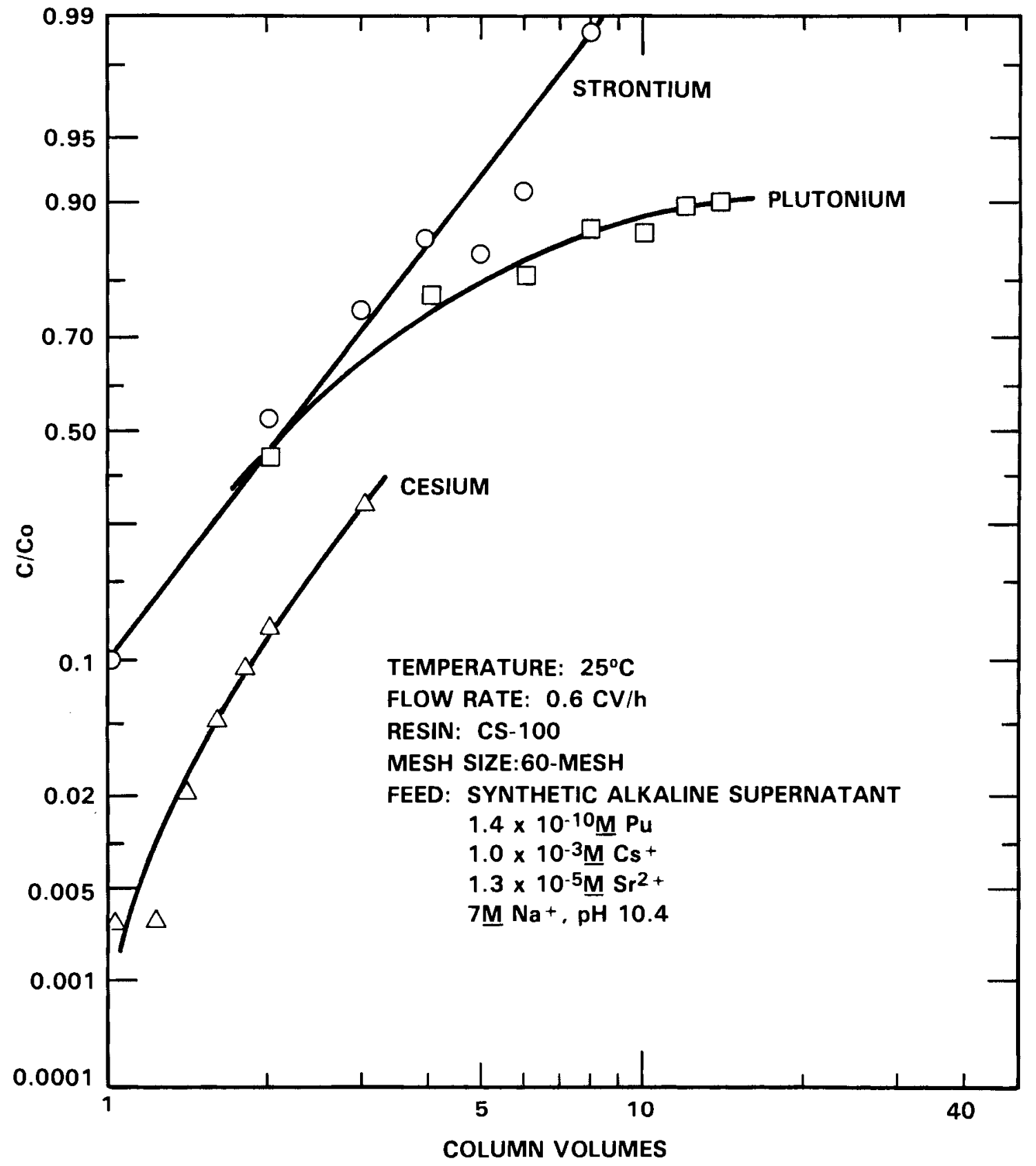

FIGURE 18. Cesium, Plutonium and Strontium Breakthrough for Organic Exchanger CS-100 at pH 10.4 


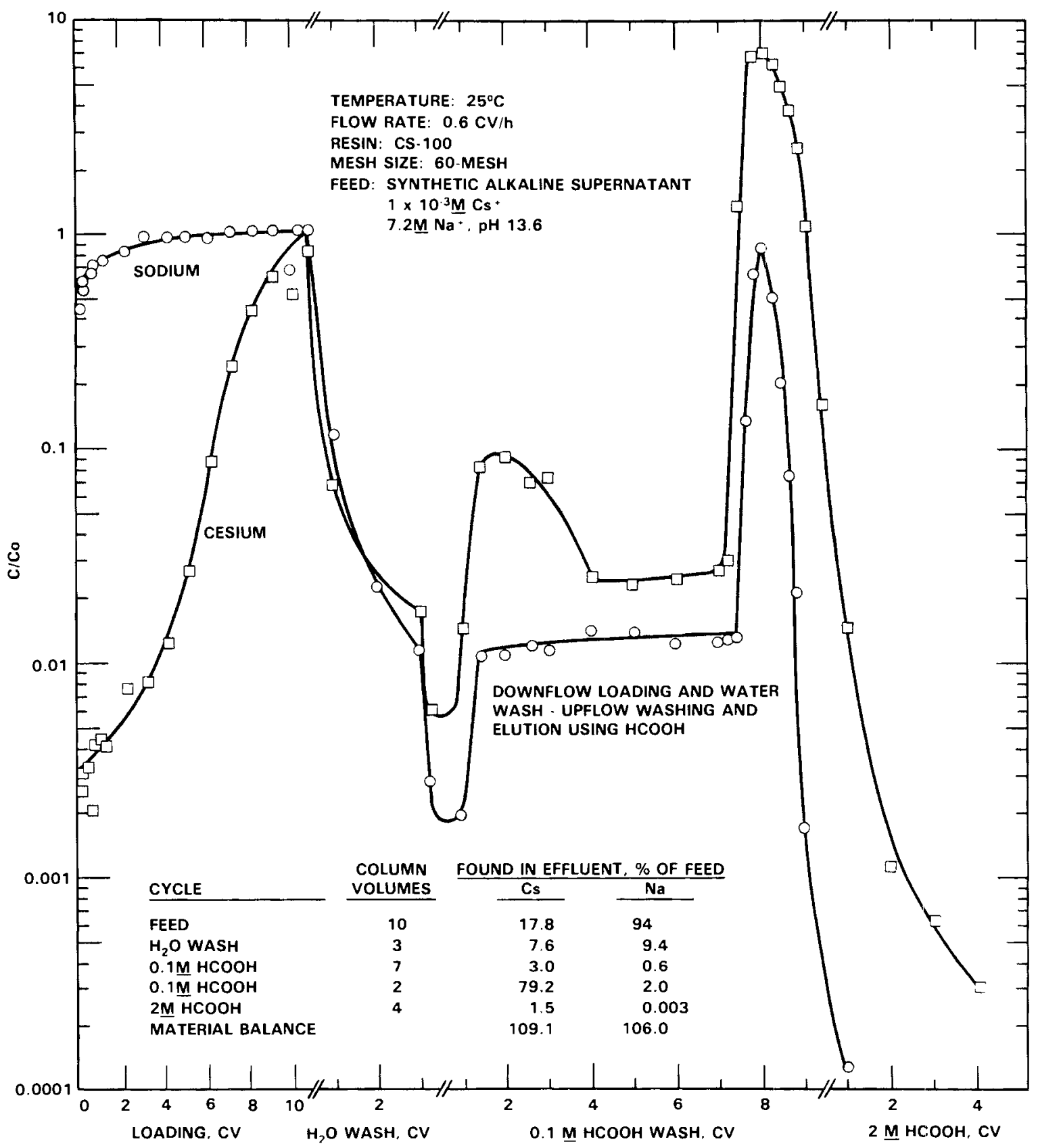

FIGURE 19. Cesium Breakthrough for Loading and Elution Cycle of Organic Exchanger CS-100 


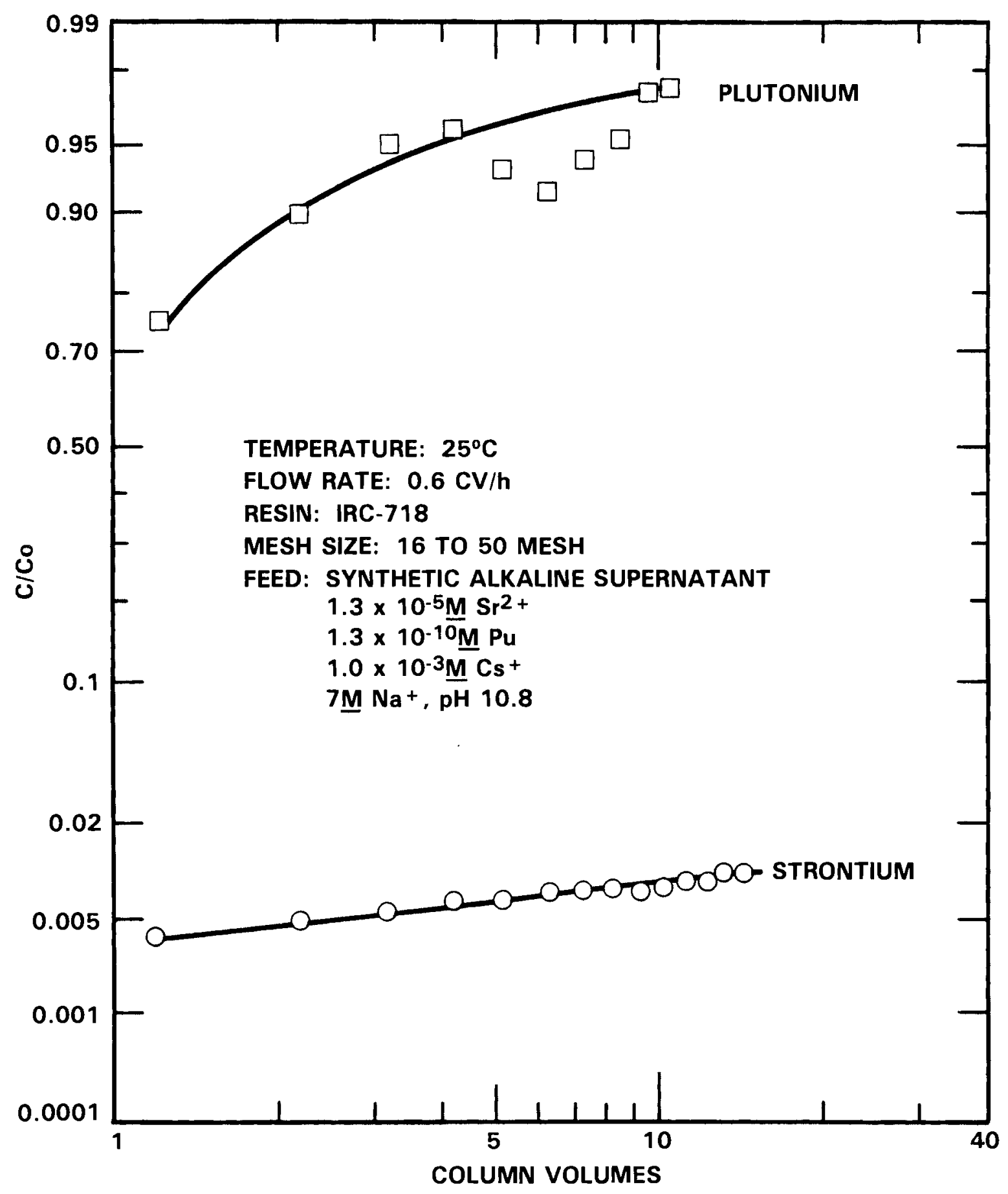

FIGURE 20. Strontium and Plutonium Breakthrough as a Function of Column Volumes Loaded for Organic Exchanger IRC-718 at pH 10.8 


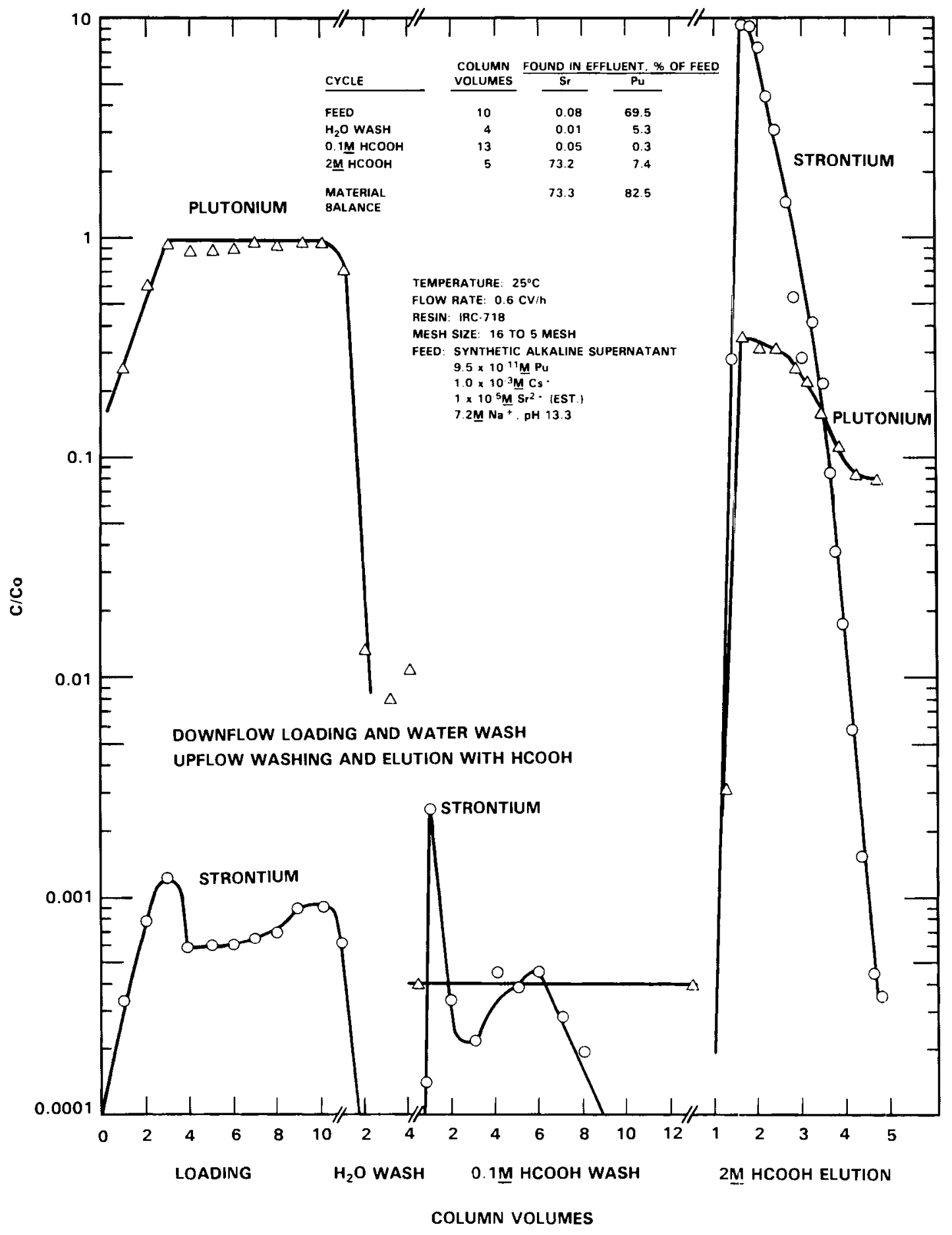

FIGURE 21. Strontium and Plutonium Breakthrough for Loading and Elution Cycle of Organic Exchanger IRC-718 at pH 13.3 
An upflow elution test (Figure 21) showed that 0.1 M formic acid will not elute $\mathrm{Sr}^{+}$or $\mathrm{Pu}\left(\mathrm{Na}^{+}\right.$data were not obtained), and that $5 \mathrm{CV}$ of $2 \mathrm{M} \mathrm{HCOOH}$ will be required to elute the $\mathrm{Sr}$ and $\mathrm{Pu}$ from the column.

Based on the above laboratory data and minimum process requirements, conditions that should achieve optimum performance for an organic ion exchange process are shown in Table 25 .

Inoryanic Ion Exchange

A simplified schematic for the inorganic ion-exchange approach at west Valley is shown in Figure 22. Alkaline supernatant $\left(2 \times 10^{6} \mathrm{~L}\right)$ is separated from Tank 802 and processed through inorganic ion exchange to remove $\mathrm{Cs}, \mathrm{Sr}$, and $\mathrm{Pu}$. The loaded and washed exchanger is fed to the vitrification process

TABLE 25. Optimum Conditions for an Organic Ion-Exchange System

Process

Parameters

Temperature

$\mathrm{pH}$

13.8

Flow rate

$\mathrm{Na}$ to Cs mole $<7000$

ratio in feed

Elution

Formic acid

Anion resin
Organic Ion Exchange

$\frac{\text { Optimum Conditions }}{25^{\circ} \mathrm{C}}$

Lower temperatures $\left(6^{\circ} \mathrm{C}\right)$ will

enhance $\mathrm{Cs}$ capacity on $\mathrm{CS}-100$ by a

factor of 1.3 , but may be

impractical to achieve.

CS-100 will achieve a Cs DF of $\sim 1600$ at 13.8. IRC -718 requires a $\mathrm{pH}$ of 13.8 to decrease $\mathrm{Pu}$ and $\mathrm{Sr}$ solubility and to achieve a Sr DF of 225 .

$\mathrm{Cs}, \mathrm{Sr}$, and $\mathrm{Pu}$ loadings are enhanced by lower flow rates.

Cs loading on CS-100 is enhanced by lower $\mathrm{Na} / \mathrm{Cs}$ mole ratios.

0.1 to 2 M.

Technetium recovery on an anion exchange resin will exceed a DF of 100. Loadings to $90 \mathrm{cv}$, followed by a $\mathrm{H}_{2} \mathrm{O}$ wash and elution using 8 $\mathrm{CV}$ of $8 \mathrm{M} \mathrm{HNO}_{3}$, will allow recycling of the resin during processing of the supernatant. 


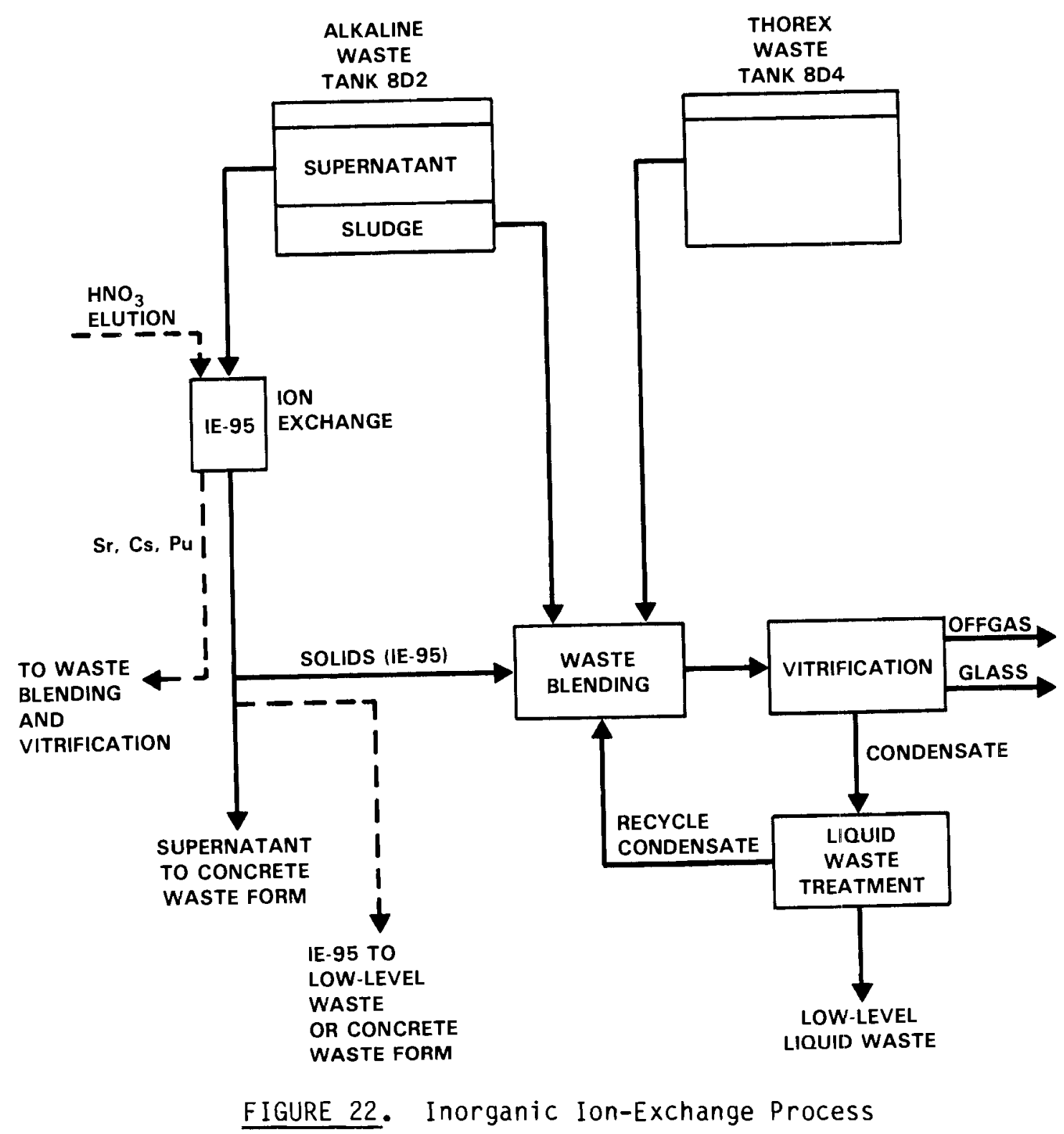

and will replace $\sim 32 \%$ of the. glass former chemicals. An alternative method is to elute the inorganic exchanger with acid and process the IE-95 as low-level waste, or to add it to the concrete waste form. The acidic eluate waste containing $\mathrm{Cs}, \mathrm{Sr}$, and $\mathrm{Pu}$ is blended and processed through vitrification. Both $\mathrm{pH}$ 10 and 13 alkaline supernatants were used in the study for comparison with the organic ion-exchange option.

The performance of inorganic zeolite ion exchanger Linde IE-95 was found to be dependent on temperature, flow rate, $\mathrm{Na} / \mathrm{Cs}$ feed ratio, and $\mathrm{pH}$. Loadings 
for Cs improved by a factor of 1.5 as the temperature was lowered from 50 to $6^{\circ} \mathrm{C}$ at $0.01 \mathrm{C} / \mathrm{Co}$. Cesium loadings decreased by a factor of 1.4 as the feed $\mathrm{pH}$ increased from 10.4 to 13.8 . At $8 \mathrm{cv}$ of feed loaded, Cs loading breakthrough fractions $(\mathrm{C} / \mathrm{Co})$ decreased by a factor of 50 as the flow rate varied from 1.75 to $0.6 \mathrm{cv} / \mathrm{h}$. Decontamination factors for $\mathrm{Cs}\left(>10^{4}\right), \operatorname{Sr}\left(\sim 10^{3}\right)$, and $\mathrm{Pu}(\sim 10)$ were achieved at the following ion-exchange column conditions: $0.6 \mathrm{cv} / \mathrm{h}, \mathrm{pH}$ $10.4,8 \mathrm{cv}$, and $25^{\circ} \mathrm{C}$. The basis for this summary is shown below.

\section{$\underline{\text { IE-95 Batch Loading }}$}

Powdered IE-95 (>80 mesh) was added to alkaline supernatant and stirred for 8 days. The test was designed to determine the value of adding zeolite directly to Tank $8 D 2$ to remove $C s$ (Figure 23$)$. The batch sorption ratios $\left(R_{d}\right)$ were 20 and 42 for $\mathrm{pH} 13.6$ and 10.4 alkaline supernatant, respectively. At an IE-95 concentration of $0.1 \mathrm{~g} / \mathrm{mL}$ of alkaline supernatant, the C/Co Cs values for $\mathrm{pH} 13.6$ and 10.4 alkaline waste were 0.32 and 0.19 , respectively. The results show that a very large mass $\left(4.3 \times 10^{5} \mathrm{~kg}\right)$ of powdered IE-95 would be required to provide a DF of 10 for Cs in Tank 8D2.

\section{$\underline{\text { IE-95 Loading }}$}

Breakthrough studies were completed using IE-95 in ion-exchange columns to determine Cs loading as a function of temperature and feed $\mathrm{pH}$. The results show that Cs loading on IE-95 is increased by lower temperatures and lower feed $\mathrm{pH}$ values (Figures 24, 25 and Table 26). At a Cs breakthrough of $0.01 \mathrm{C} / \mathrm{Co}$, the volumes of feed (at $\mathrm{pH} 10.4$ ) loaded varied from 17 (at $6^{\circ} \mathrm{C}$ ) to 11 (at $50^{\circ} \mathrm{C}$ ). At a feed $\mathrm{pH}$ of 13.6 , the volumes of feed loaded decreased to 13.5 (at $6^{\circ} \mathrm{C}$ ) and $9.6\left(\right.$ at $\left.50^{\circ} \mathrm{C}\right)$.

Cesium loading on IE-95 was enhanced by lower alkaline supernatant flow rates (see Figure 26 ). At feed flow rates $(\mathrm{cv} / \mathrm{h})$ of $0.6,1.0$ and 1.8 , the $\mathrm{Cs}$ breakthrough fraction $\left(C / C_{0}\right)$ was determined to be $4.0 \mathrm{E}-5,2.0 \mathrm{E}-4$ and $2.0 \mathrm{E}-3$, respectively, after eight column volumes of feed had passed through the column.

A series of experiments was completed using alkaline supernatant at $\mathrm{pH} 10.4$ containing $6 \times 10^{-5} \underline{\mathrm{M}} \mathrm{Cs}^{+}, 4.5 \times 10^{-4} \underline{\mathrm{M}} \mathrm{Cs}^{+}$, or $1 \times 10^{-3} \underline{\mathrm{M}} \mathrm{Cs}^{+}$at $\underline{7 \mathrm{M}} \mathrm{Na}^{+}$ (see Figure 27). The cesium feed concentration was adjusted by using the effluent from one run as the feed for the next. A similar series was completed 


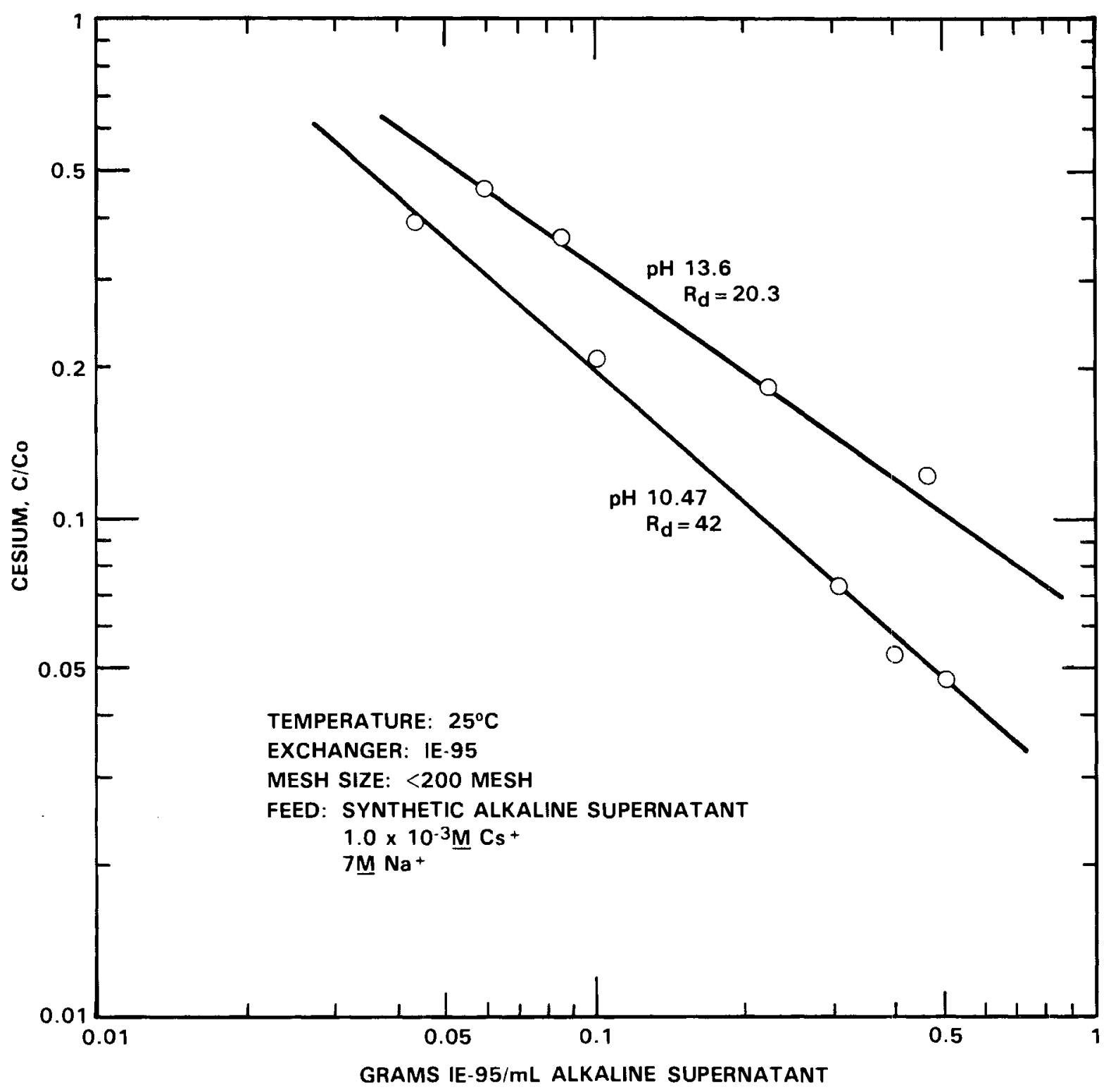

FIGURE 23. Cesium in Solution as a Function of Added Powdered Zeolite Exchanger IE-95

in which the Cs was varied in the initial feed. 'The breakthrough results for the two methods of feed preparation were similar, indicating that $\mathrm{K}^{+}$and $\mathrm{Rb}^{+}$ ions do not interfere with the IE-95 Cs-loading capacity. The Cs capacity of IE-95 decreased with increasing $\mathrm{Na} / \mathrm{CS}$ mole ratio in the alkaline supernatant as shown in Table 27. 


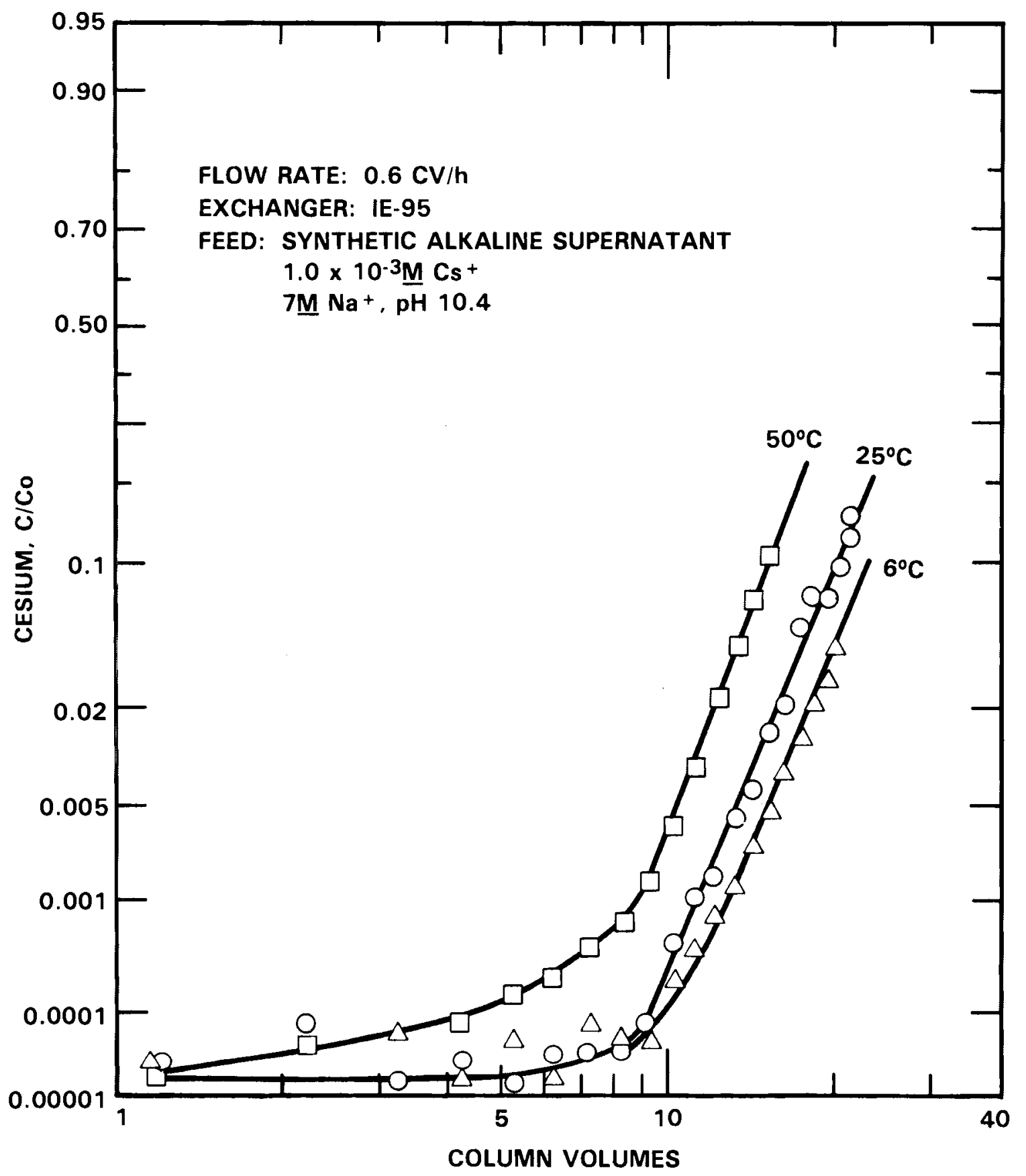

FIGURE 24. Cesium Breakthrough as a Function of Temperature for the Zeolite Exchanger IE-95 at pH 10.4 


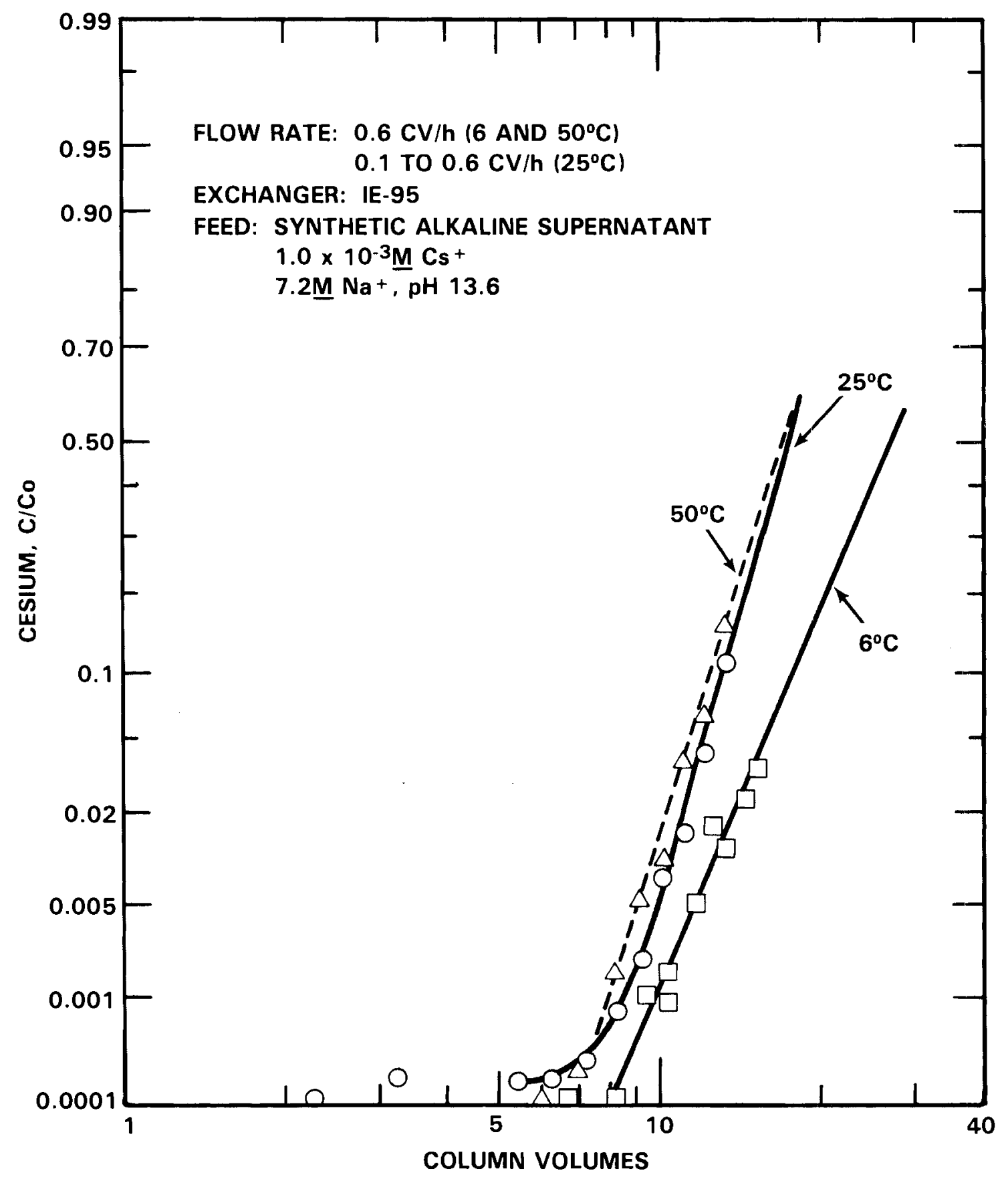

FIGURE 25. Cesium Breakthrough as a Function of Temperature for the Zeolite Exchanger IE-95 at pH 13.6 
TABLE 26. Volumes of Feed Loaded as a Function of Temperature and pH

\begin{tabular}{|c|c|c|c|}
\hline Alkaline & \multicolumn{3}{|c|}{$\begin{array}{c}\text { Column volumes at } \\
0.01 \mathrm{C} / \mathrm{Co}\end{array}$} \\
\hline Supernatant, $\mathrm{pH}$ & $6^{\circ} \mathrm{C}$ & $25^{\circ} \mathrm{C}$ & $50^{\circ} \mathrm{C}$ \\
\hline 10.4 & 17 & 14.5 & 11 \\
\hline 13.6 & 13.5 & 10.4 & 9.6 \\
\hline
\end{tabular}

Cesium, Pu, and Sr IE-95 inorganic ion-exchange results are shown in Figures 24,28 , and 29 as a function of throughput temperatures for different, using $\mathrm{pH} 10.4$ alkaline supernatant. The results at $25^{\circ} \mathrm{C}$ show that the instantaneous Cs, Sr, and Pu DFs of $10^{4}, 224$, and 6 are not exceeded until more than 9,12 , and $8 \mathrm{cv}$ of feed are passed through the column, respectively. Loading of $\mathrm{Cs}, \mathrm{Sr}$, and $\mathrm{Pu}$ is temperature dependent. However, the $\mathrm{Pu}$ and $\mathrm{Sr}$ curves show kinetic and equilibrium problems not identified in the batch equilibrium studies. At $8 \mathrm{cv}$, the $\mathrm{C} / \mathrm{Co}_{0}$ values shown in Table 28 were obtained.

\section{IE-95 Elution}

Cesium, $\mathrm{Sr}$, and Pu are effectively eluted from IE-95 using $4 \mathrm{M} \mathrm{HNO}_{3}$. However, in an ion-exchange column, gas due to the presence of carbonate ion will tend to disrupt the flow of the eluate. Batch may be more viable than column elution.

Cesium can be removed from zeolites by cations that are similar in size and charge to $\mathrm{Cs}\left(\mathrm{K}^{+}, \mathrm{Rb}^{+}\right.$, and $\mathrm{NH}_{4}^{+}$). At Hanford (Buckingham 1967), sodium is selectively scrubbed from AW-500 with $0.2 \mathrm{M}\left(\mathrm{NH}_{4}\right)_{2} \mathrm{CO}_{3}-0.1 \mathrm{M} \mathrm{NH}_{4} \mathrm{OH}$, and then the $\mathrm{Cs}^{+}$is eluted at $55^{\circ} \mathrm{C}$ with 4 to $8 \mathrm{M} \mathrm{NH}_{4}^{+}$with about $75 \%$ of the $\mathrm{NH}_{4}^{+}$added as $\left(\mathrm{NH}_{4}\right)_{2} \mathrm{CO}_{3}$, and $25 \%$ added as $\mathrm{NH}_{4} \mathrm{OH}$.

Acid elution of IE-95 was considered as an option to direct waste blending (Figure 22). Initial batch contacts of CS-loaded IE-95 (Table 29) show that Cs can be stripped. Cesium $R_{d}$ values of 3 and 0.1 were obtained using 0.5 and $2 M$ $\mathrm{HNO}_{3}$, respectively. Formic acid was not efficient in the removal of $\mathrm{Cs}$ from IE-95.

Based on the Cs batch contacts, IE-95 column tests were completed by loading $20 \mathrm{CV}$ of $\mathrm{pH} 10.4$ alkaline supernatant; washing the column with water; and eluting the $\mathrm{Sr}, \mathrm{Cs}$, and $\mathrm{Pu}$ using $1 \mathrm{M} \mathrm{HNO}_{3}$ (Figure 30) or $4 \underline{\mathrm{M}} \mathrm{HNO}_{3}$ 


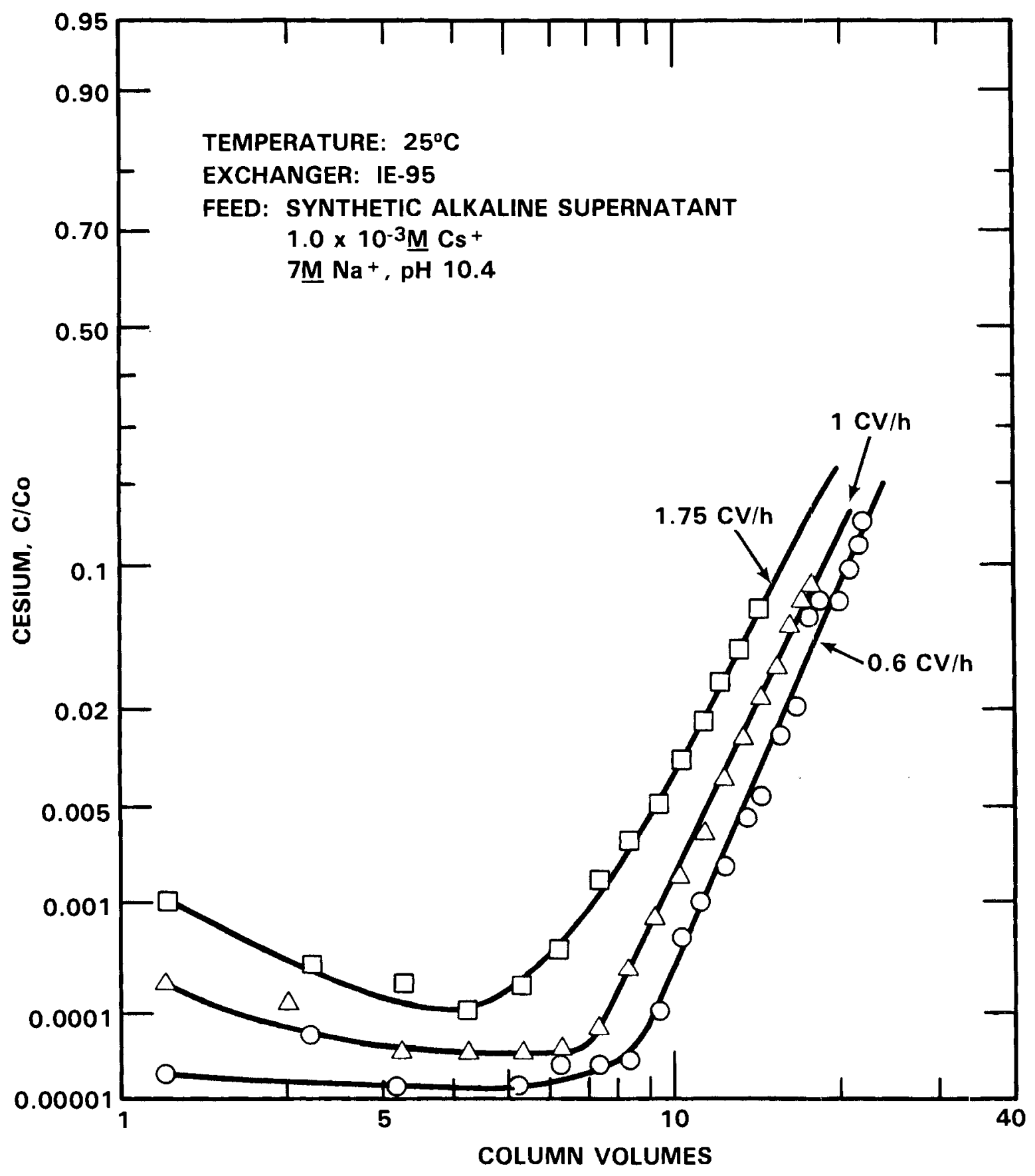

FIGURE 26. Cesium Breakthrough as a Function of Flow Rate for Zeolite Exchanger IE-95 at $\mathrm{pH} 10.4$ 


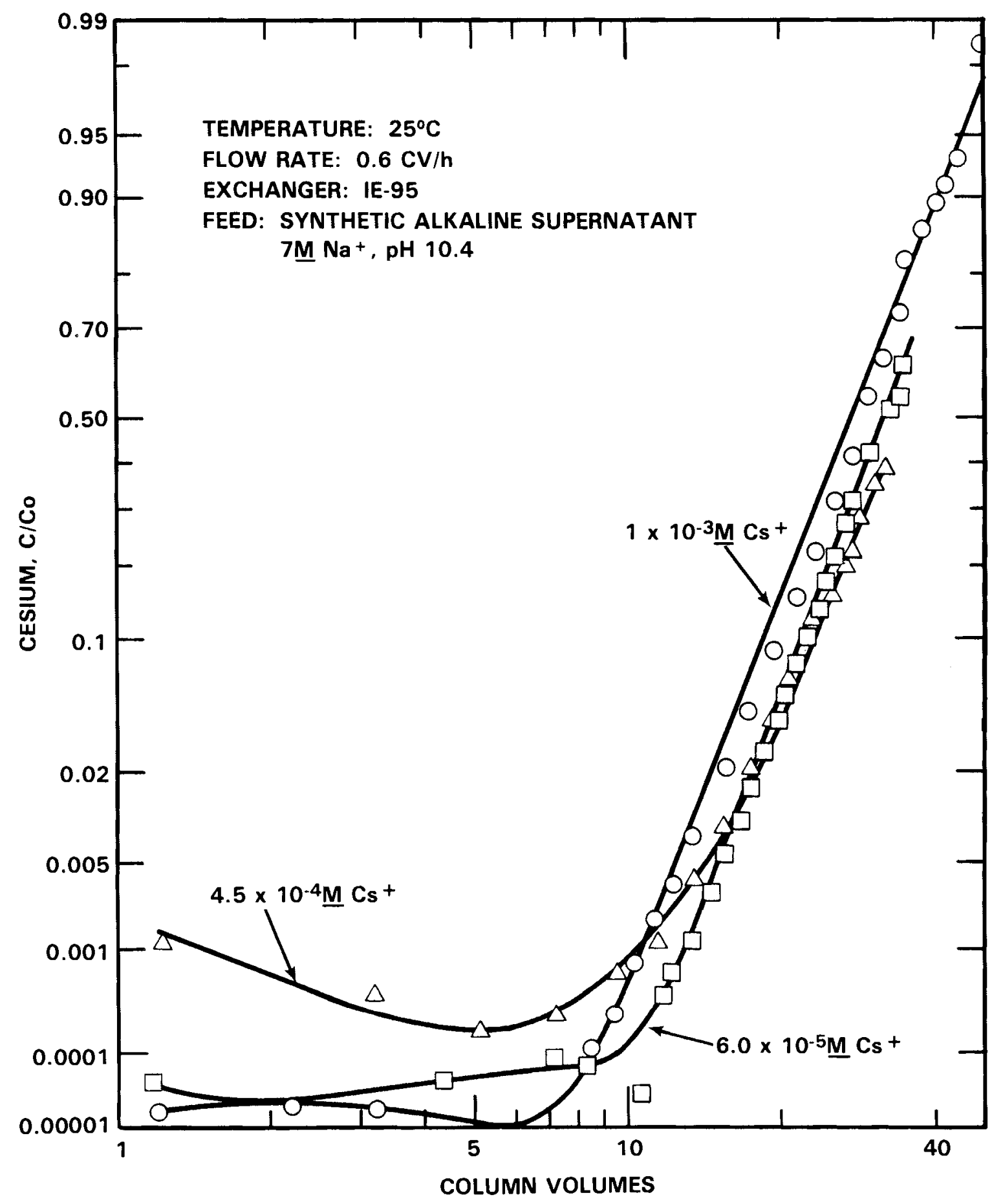

FIGURE 27. Cesium Breakthrough as a Function of the Influent Cesium Concentration for the Zeolite Exchanger IE-95 
TABLE 27. Cesium Loaded on IE-95 as a Function of Na/Cs Mole Ratio

\begin{tabular}{|c|c|c|}
\hline $\begin{array}{l}\mathrm{Na} / \mathrm{Cs} \text { Mole } \\
\quad \text { Ratio } \\
\end{array}$ & $\begin{array}{r}\text { Column Volumes } \\
\text { at } 0.01 \mathrm{C} / \mathrm{Co} \\
\end{array}$ & $\begin{array}{c}\text { Moles Cs Loaded/L } \\
\text { of IE-95 } \\
\end{array}$ \\
\hline $7.0 E+3$ & 13 & $1.3 \mathrm{E}-2$ \\
\hline $1.56 E+4$ & 16 & $7.1 \mathrm{E}-3$ \\
\hline $1.17 E+5$ & 16 & $9.6 \quad E-4$ \\
\hline
\end{tabular}

(Figure 31). To obtain a $\mathrm{C} / \mathrm{Co}$ value of $0.01,21$ and $6.5 \mathrm{cv}$ of 1 and $4 \underline{M} \mathrm{HNO}_{3}$ were required, respectively. The zeolite bed was disrupted during acid elution due to the formation of $\mathrm{CO}_{2}$ gas in both tests, which may account for the unusual elution profiles. However, the $\mathrm{Sr}$ may be associated with the calcium carbonate, which dissolves readily in $\mathrm{HNO}_{3}$. The resulting eluted exchangers were sized to determine physical destruction due to the $\mathrm{NHO}_{3}$ eluated. No major size reduction was noted. Reuse of the exchanger has not been tested, but nearly total loss in cesium loading is expected.

Based on the above laboratory data and minimum process requirements, conditions that should achieve optimum performance for an inorganic ionexchange system are shown in Table 30.

Technetium Organic Anion Exchange

Recovery of Tc from alkaline supernatant has been studied at Hànford (Buckingham 1967). Roberts, Smith, and Wheelwright (1963) recovered more than $1 \mathrm{~kg}$ of Tc from the PUREX alkaline supernatant as part of an early fission product utilization study, and a flowsheet was developed (Beard 1964). Technetium is found in the West valley waste supernatant as a soluble pertechnetate anion, $\mathrm{TCO}_{4}{ }^{-}$. Initial reports on the radiochemical composition of Tank 8D2 predicted that the $\mathrm{TC}$ would be found as $\mathrm{Ba}\left(\mathrm{TCO}_{4}\right)_{2}$ in the sludge phase. More recent studies show that $92 \mathrm{~kg}(1600 \mathrm{C} i)$ of $\mathrm{TC}(90 \%)$ will be found in the supernatant phase.

Technetium $R_{d}$ values (Table $2 \dot{q}$ ) show that the quaternary ammoniun polystyrene, strong-base anion exchange resins will recover $\left(T c R_{d}=223\right.$ ) the $\mathrm{TcO}_{4}{ }^{-}$anion from synthetic West valley supernatant of $\mathrm{pH} \mathrm{10.4.} \mathrm{The} \mathrm{results} \mathrm{for}$ a single ion exchange column loading and elution test using Dowex $-1, x 8$ resin are summarized below. 


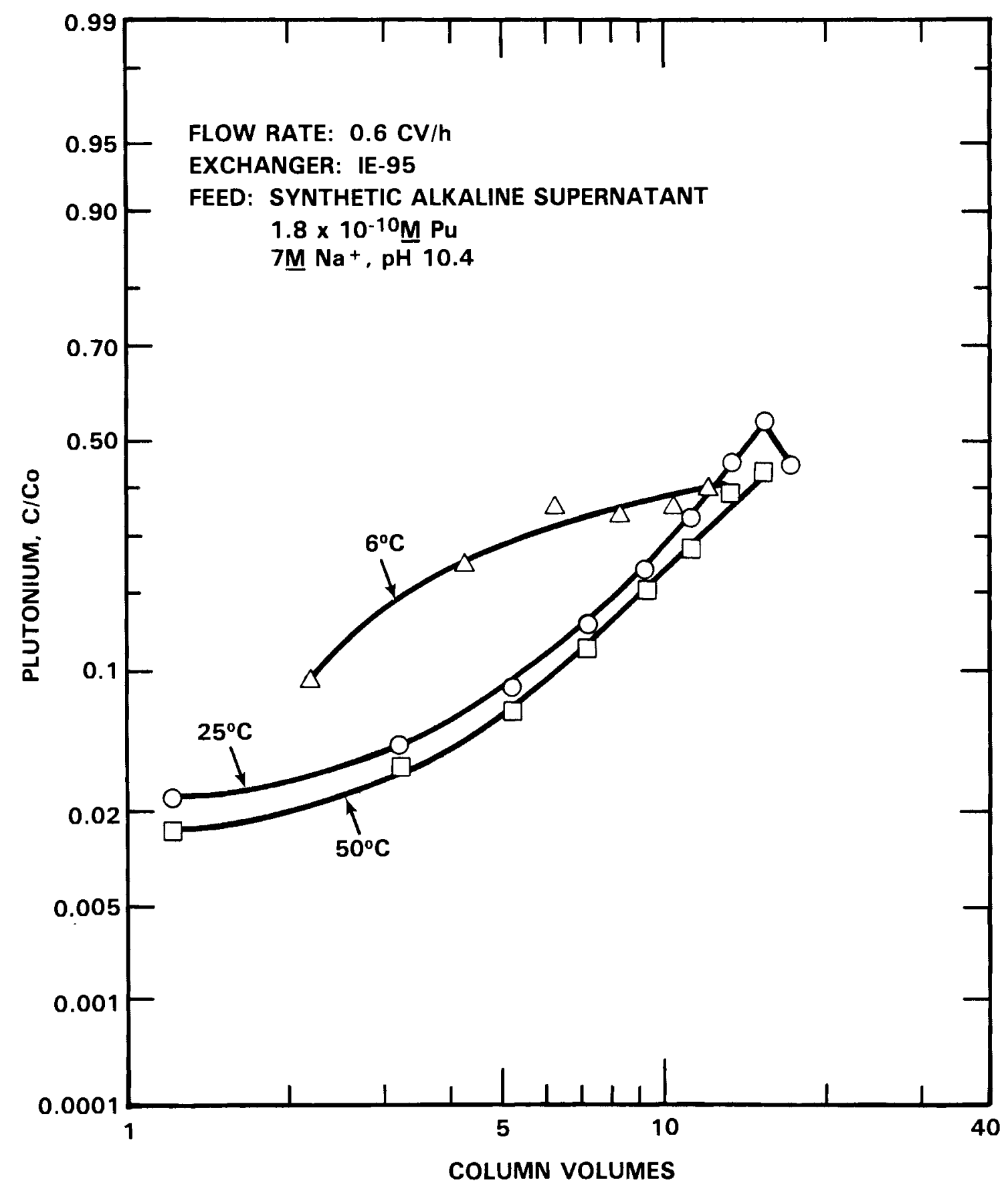

FIGURE 28. Plutonium Breakthrough as a Function of Temperature for Zeolite Exchanger IE-95 


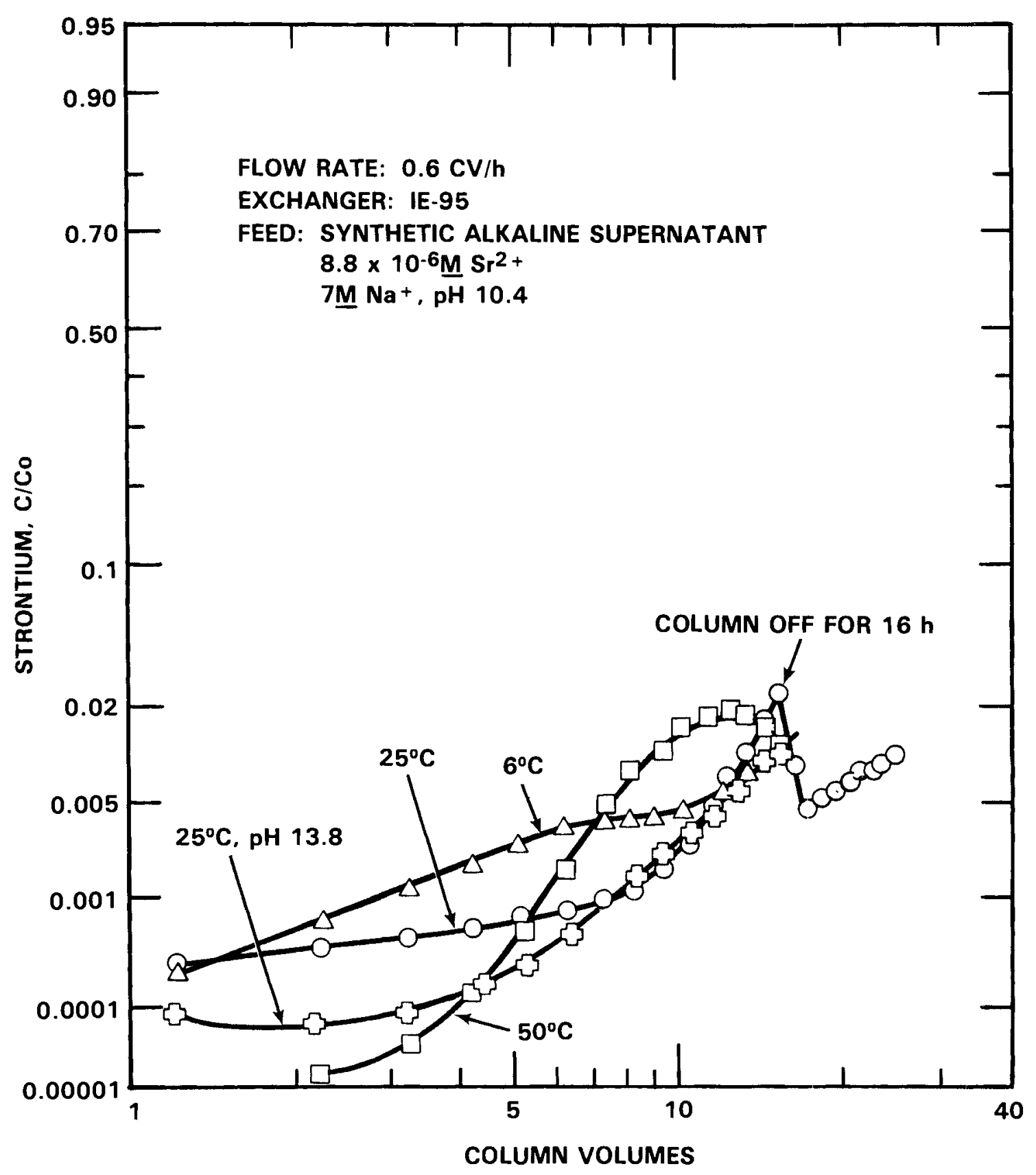

FIGURE 29. Strontium Breakthrough as a Function of Temperature for Zeolite Exchanger IE-95 
TABLE 28. Breakthrough Values for IE-95 as a Function of Temperature

\begin{tabular}{|c|c|c|c|}
\hline Element & $\frac{\text { Breakthr }}{6^{\circ} \mathrm{C}}$ & $\frac{\text { ugh Fract }}{25^{\circ} \mathrm{C}}$ & $\frac{\text { on, } \mathrm{C} / \mathrm{Co}}{50^{\circ} \mathrm{C}}$ \\
\hline $\mathrm{Cs}$ & 4.0 E-5 & 5.0 E-5 & $6.5 \mathrm{E}-4$ \\
\hline $\mathrm{Sr}$ & $4.0 \mathrm{E}-3$ & $1.0 \mathrm{E}-3$ & $7.0 \mathrm{E}-3$ \\
\hline $\mathrm{Pu}$ & $3.5 \mathrm{E}-1$ & $1.9 \mathrm{E}-1$ & $1.5 \mathrm{E}-1$ \\
\hline
\end{tabular}

TABLE 29. Batch Elution of IE-95 Using Nitric and Formic Acid(a)

\begin{tabular}{|c|c|c|c|c|}
\hline Acid & $\begin{array}{l}\text { Loading, } \\
\text { CS Rd }\end{array}$ & $\begin{array}{l}\% \text { of Initial Cs } \\
\text { That Loaded } \\
\end{array}$ & $\begin{array}{l}\text { Stripping, } \\
\text { CS R } \\
\end{array}$ & $\begin{array}{l}\% \text { of Initial Cs } \\
\text { That Stripped }\end{array}$ \\
\hline $0.5 \mathrm{M} \mathrm{HNO}_{3}$ & $3.3 \mathrm{E}+1$ & 23.8 & $3.1 E+0$ & 23.2 \\
\hline $2 \underline{M} \mathrm{HNO}_{3}$ & $3.4 E+1$ & 24.0 & $0.1 E-1$ & 24.5 \\
\hline $0.1 \mathrm{M} \mathrm{HCOOH}$ & $3.4 E+1$ & 23.8 & $1.3 E+4$ & 0.2 \\
\hline $2 \mathrm{M} \mathrm{HCOOH}$ & $3.4 E+1$ & 24.0 & $4.7 E+2$ & 4.5 \\
\hline
\end{tabular}

(a) Conditions: Batch contact $0.1 \mathrm{~g}$ of $\mathrm{IE}-95$ with $10 \mathrm{~mL}$ of West valley synthetic waste, $\mathrm{pH} 10.8,1.1 \times 10^{-3} \mathrm{M} \mathrm{Cs}$, for 24 hours. Determine $\mathrm{R}_{\mathrm{d}}$ value for loading. Wash exchanger with two $10-\mathrm{mL}$ contacts of $\mathrm{H}_{2} \mathrm{O}$. Contact exchanger with formic or nitric acid for 24 hours.

\section{Dowex $-1, x 8$ Loading and Elution}

Synthetic alkaline supernatant ( $\mathrm{pH}$ 10.4) was adjusted to a Tc content of $0.044 \mathrm{~g} / \mathrm{L}$. The feed was passed through a $100 \mathrm{~mL}$ ion-exchange column containing Dowex-1, $x 8$ resin in the nitrate form at $0.6 \mathrm{cv} / \mathrm{h}$ (Figure 32 ). A $0.01,0.1$, and $0.5 \mathrm{C} / \mathrm{Co}$ Tc breakthrough occurred at 84,91 , and $100 \mathrm{cv}$, respectively. After washing the column of resin with $\mathrm{H}_{2} \mathrm{O}$, the $\mathrm{TcO}_{4}{ }^{-}$was eluted with $9 \mathrm{cr}$ of $8 \mathrm{M}$ $\mathrm{HNO}_{3}$, with an average concentration of $\sim 0.5 \mathrm{~g} \mathrm{TC} / \mathrm{L}$ (Figure 33). The maximum eluate concentration was 30 times the feed concentration, or $1.3 \mathrm{~g} \mathrm{TC} / \mathrm{L}$. A DF of 100 was achieved after $90 \mathrm{cv}$ of feed were 1oaded. Greater than $99 \%$ of the TC was recovered from the Dowex-1, X8 resin with $9 \mathrm{CV}$ of $8 \mathrm{M} \mathrm{HNO}_{3}$.

\section{ASSESSMENT OF ION-EXCHANGE CANDIDATES FOR CESIUM RECOVERY}

Organic ion-exchange resin CS-100 and inorganic exchanger IE-95 were selected for ion-exchange column testing based on an initial batch screening 


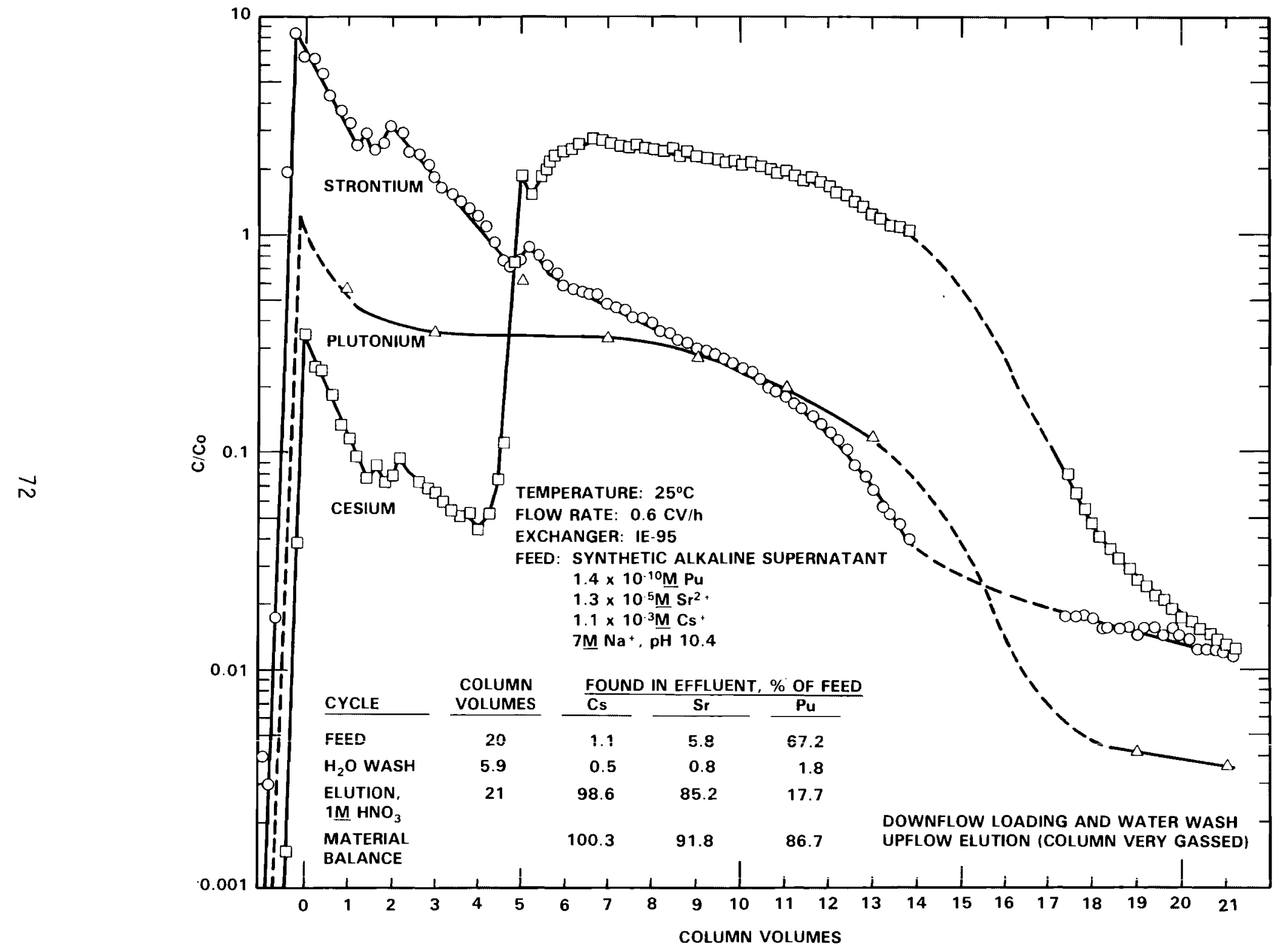

FIGURE 30. Elution of the Zeolite Exchanyer IE-95 Using $1 \mathrm{M} \mathrm{HNO}_{3}$ 


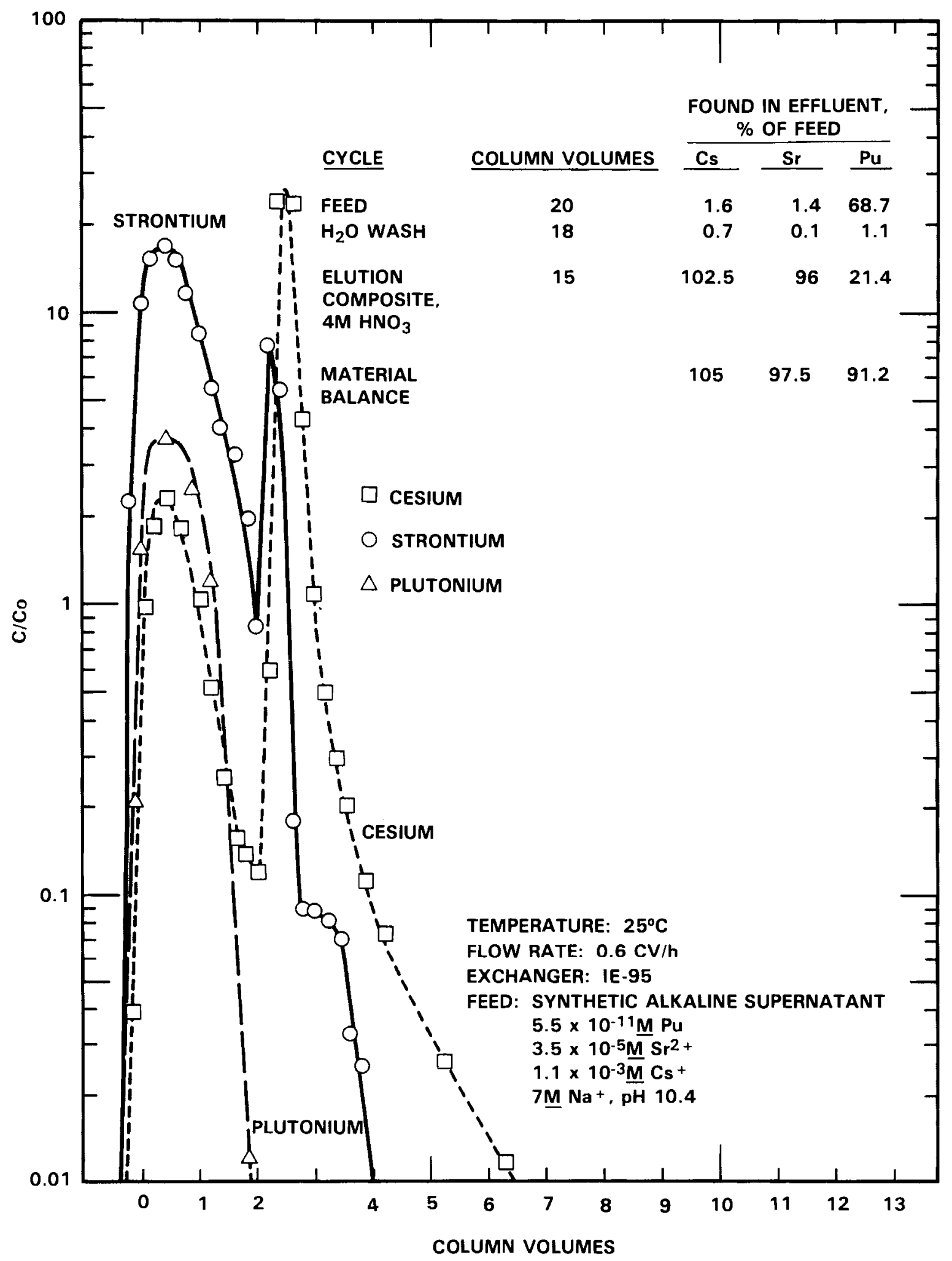

FIGURE 31. Elution of the Zeolite Exchanger IE-95 Using 4M $\mathrm{HNO}_{3}$ 
TABLE 30. Optimum Conditions for an Inorganic Ion-Exchange System

Process

Parameters

Temperature $\quad 25^{\circ} \mathrm{C}$
Inorganic Ion Exchange

Optimum Conditions Comments

Lower temperatures $\left(6^{\circ} \mathrm{C}\right)$ will enhance $\mathrm{Cs}$ capacity on both CS-100 and IE-95 by a factor of 1.2. Higher temperatures may enhance $\mathrm{Pu}$ and $\mathrm{Sr}$ recovery on IE-95. However, higher temperatures provide adverse Cs loadings.

$\mathrm{pH} \quad 10.4$

$0.6 \mathrm{cv} / \mathrm{h}$

Flow rate

Na to Cs mole $<7000$

ratio in feed

$1 \times 10^{5} \mathrm{~kg}$

Mass of IE-95

required for

Tank 8D2

Elution

(optiona1)

$\mathrm{HNO}_{3}$
IE-95 will provide a Cs DF of $10^{4}$, a Sr DF of 225 and a Pu DF of 6 .

Cs, Sr, and Pu loadings are enhanced by lower flow rates.

Cs loading on IE-95 is enhanced

by lower $\mathrm{Na} / \mathrm{Cs}$ mole ratios.

Process will use three or more ionexchange beds in series, front bed loaded to capacity ( $20 \mathrm{cv})$ to optimize the process. Zeolite does not impact the glass mass $\left(\mathrm{Al}_{2} \mathrm{O}_{3}\right.$ in glass $\left.-6 \mathrm{wt} \%\right)$.

Zeolite loading/elution cycling is impractical due to exchanger breakup. Eluted zeolite can be packaged and disposed of as LLW or added to the concrete. Eluate (nitric acid) may require acid destruction. Batch elution may be viable. Column elution may not be viable due to gas formation during elution.

process. They were tested in a 100-mL ion-exchange column with synthetic West Valley alkaline supernatant to examine key process variables such as $\mathrm{pH}$, temperature, and loading capacity. A comparative evaluation of the ionexchange candidates is discussed below.

$\underline{\mathrm{pH}}$

The West Valley Tank 802 contains $2.1 \times 10^{6} \mathrm{~L}$ of alkaline supernatant at a $\mathrm{pH}$ of $\sim 10$. The exchangers were tested to determine the effect of $\mathrm{pH}$. The capacity for Cs as a function of $\mathrm{pH}$ showed that IE-95 inorganic exchanger provided more CS capacity at either pH 10 or 13, as compared to CS-100 (see 


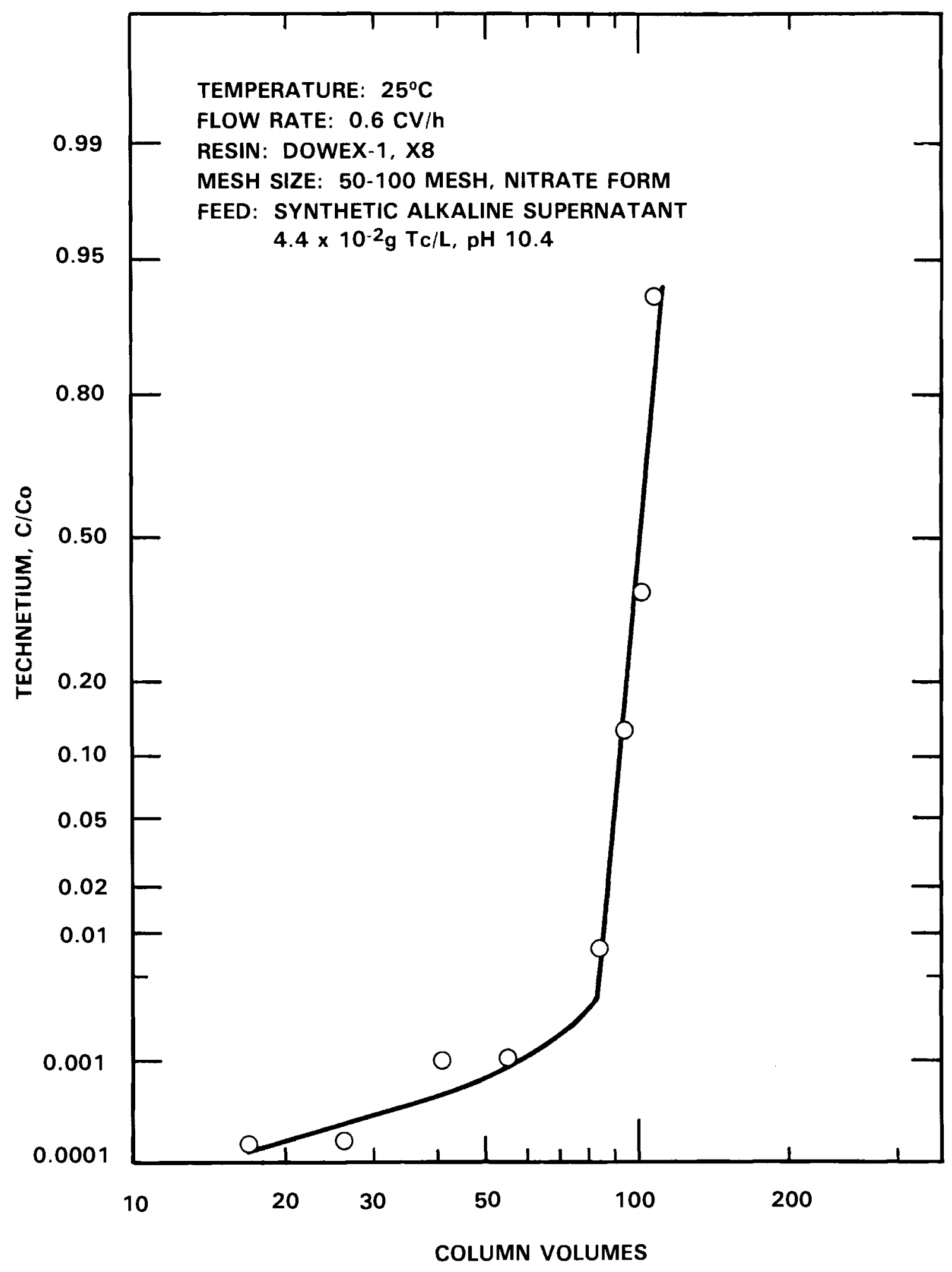

FIGURE 32. Technetium Breakthrough for Organic Anion Resin Dowex-1,X8 


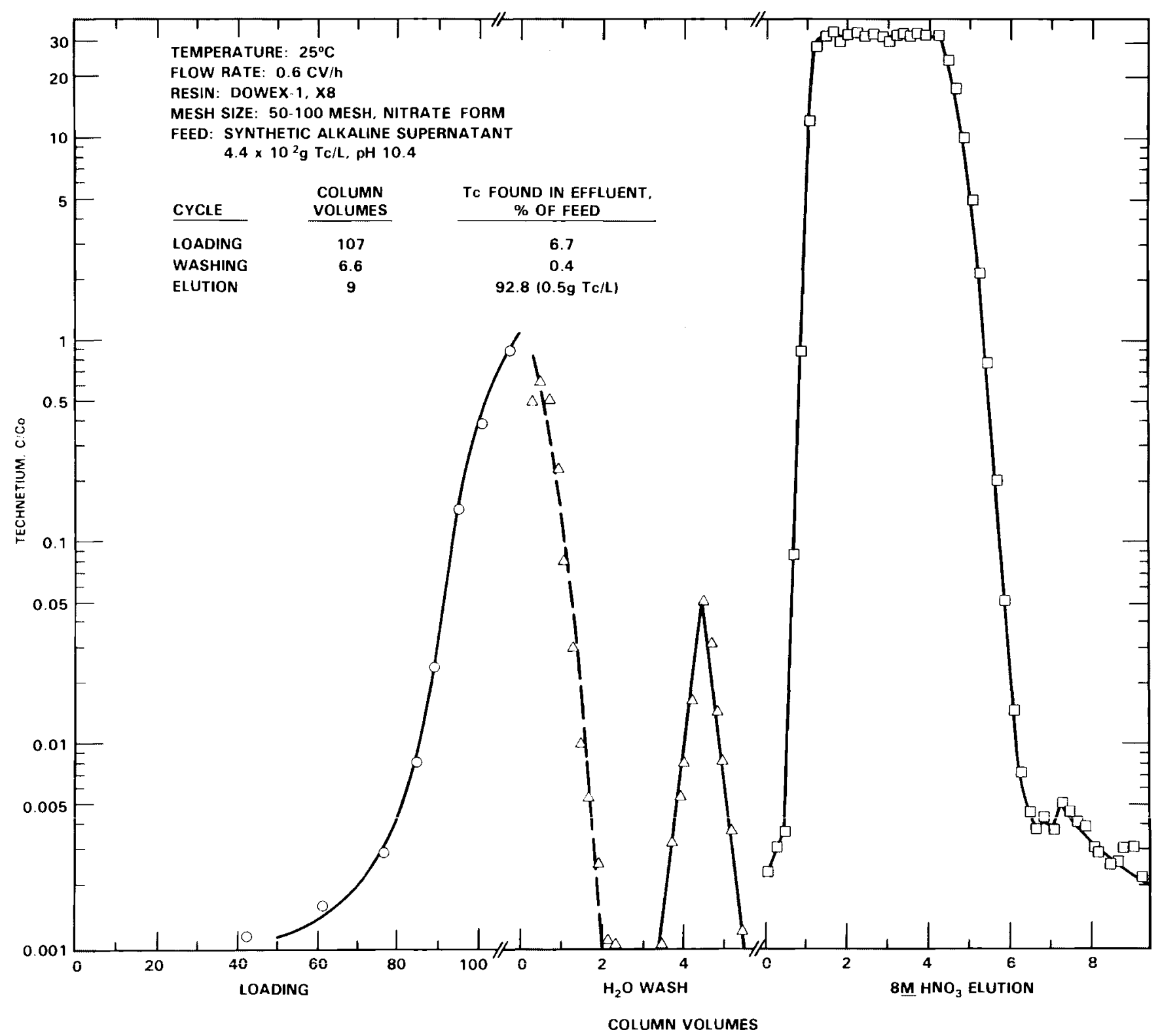

FIGURE 33. Technetium Breakthrough for Loading and Elution Cycles of Organic Anion Resin Dowex-1, $x 8$ 
Figure 34 and Table 31). The Cs capacity expressed in $C V$ of feed loaded at 0.5 $\mathrm{C} / \mathrm{Co}$ breakthrough increased from 2.6 to $8.5 \mathrm{cV}$ for CS-100, while the capacity on IE-95 decreased from 31 to $19 \mathrm{cv}$, as the feed pH varied from 10.4 to 13.6. The ratio of IE-95 capacity for Cs to CS-100 capacity was 12 at pH 10.4, and 2.2 at $\mathrm{pH} 13.6$.

\section{Temperature}

Increased temperature had an adverse effect on $\mathrm{Cs}^{+}$loading for both IE-95 (Figure 16) and CS-100 (Figure 24). This effect was caused by partial dehydration of the $\mathrm{Na}^{+}$ion at elevated temperatures, which increased its ability to compete with the unhydrated $\mathrm{Cs}^{+}$ion. The $\mathrm{Cs}^{+}$capacity of IE-95 is higher than CS-100 at $0.5 \mathrm{C} / \mathrm{Co}_{0}$ by a factor of $\sim 3$, as the temperature is varied from 6 to $50^{\circ} \mathrm{C}$ (see Figure 35 and Table 32 ).

Cesium Loading Capacity

The Cs loading capacity for both IE-95 (Figure 27) and CS-100 (Figure 17) at $0.5 \mathrm{C} / \mathrm{Co}$ is dependent on the $\mathrm{Na} / \mathrm{Cs}$ mole ratio of the alkaline supernatant feed. The loading results are compared in Table 33 and Figure 36 . Assuming that loading is independent of $\mathrm{pH}, \mathrm{Cs}$ loads onto IE-95 by a factor of $>2$ more than onto CS-100 for the same $\mathrm{Na} / \mathrm{Cs}$ mole ratio. The $\mathrm{Na}$ to $\mathrm{Cs}$ mole ratio for the West Valley alkaline supernatant was assumed to be $\sim 7000$ for this study, and the Cs-loading capacity on IE-95 (pH 10.4) was greater by a factor of 3.6 than on CS-100 (pH 13.6). 


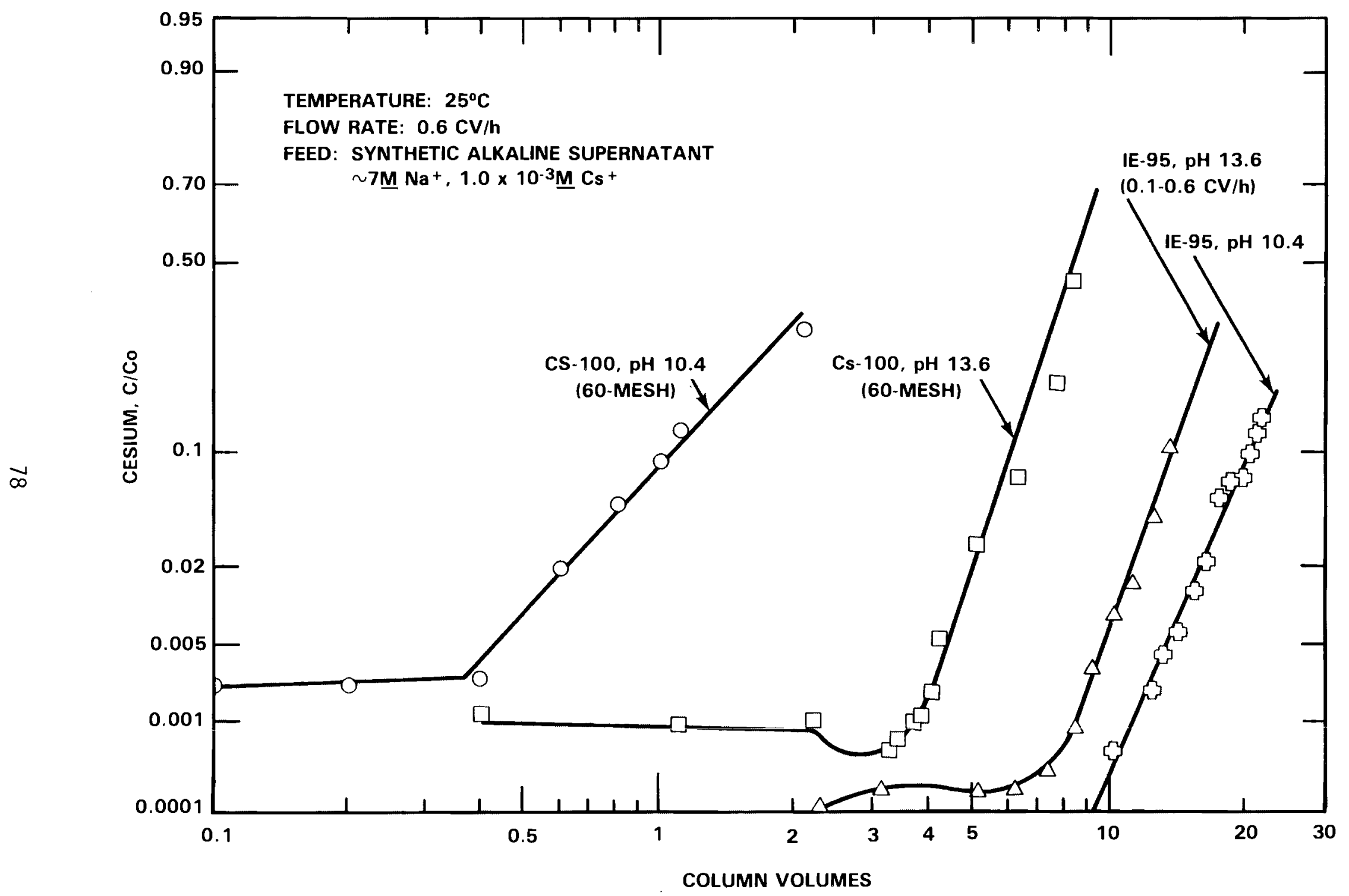

FIGURE 34. Cesium Breakthrough as a Function of Exchanger and Feed pH 
TABLE 31. Cesium Loading Capacity on IE-95 and CS-100 as a Function of $\mathrm{pH}$ for the West Valley Synthetic Alkaline Supernatant $(a)$

Alkaline Supernatant $\quad \mathrm{pH} 10.4 / \mathrm{pH} 13.6$

pH 10.4 pH 13.6 Cs Capacity Ratio

\begin{tabular}{|c|c|c|c|}
\hline CS -100 & & & \\
\hline Column volumes & $2.6 E+0$ & $8.5 E+0$ & \\
\hline $\begin{array}{c}\text { Moles Cs loaded } \\
\text { per L of CS-100 } \\
\text { IE-95 }\end{array}$ & $2.6 E-3$ & $8.5 \quad E-3$ & $3.0 \mathrm{E}-1$ \\
\hline Column volumes & $3.1 E+1$ & $1.9 E+1$ & \\
\hline $\begin{array}{l}\text { Moles Cs loaded } \\
\text { per } L \text { of IE-95 }\end{array}$ & $3.1 E-2$ & $1.9 E-2$ & $1.6 E+0$ \\
\hline $\begin{array}{l}\text { IE- } 95 / C S-100 \\
\text { Cs capacity ratio }\end{array}$ & $1.2 E+1$ & $2.2 E+0$ & \\
\hline
\end{tabular}

(a) Conditions: $\sim 7 \mathrm{M} \mathrm{Na}{ }^{+}, 1 \times 10^{-3} \mathrm{M} \mathrm{Cs}{ }^{+}, 25^{\circ} \mathrm{C}$. Breakthrough: $\bar{C} / C_{0}=0.5$. 


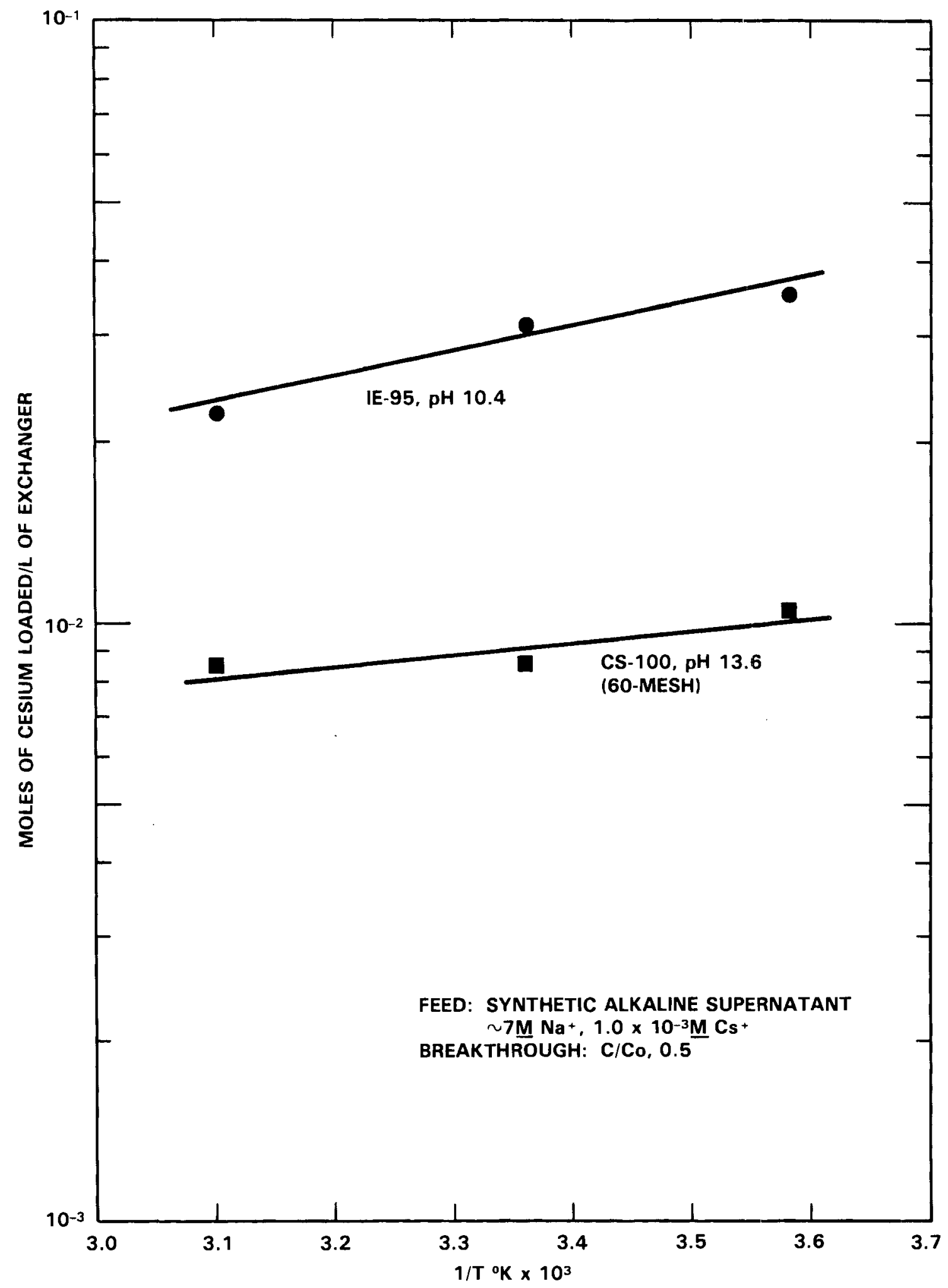

FIGURE 35. Cesium Loading Capacity as a Function of Temperature 
TABLE 32. Cesium Loading Capacity on IE-95 and CS-100 as a Function, of Temperature for the West Valley Alkaline Supernatant (a)

\begin{tabular}{|c|c|c|c|}
\hline \multirow[b]{3}{*}{$\mathrm{CHH}$} & \multicolumn{3}{|c|}{ Temperature } \\
\hline & $50^{\circ} \mathrm{C}$ & $25^{\circ} \mathrm{C}$ & $6^{\circ} \mathrm{C}$ \\
\hline & & & \\
\hline Column volumes & $8.5 E+0$ & $8.5 E+0$ & $1.1 E+1$ \\
\hline $\begin{array}{l}\text { Moles Cs loaded } \\
\text { per } L \text { of CS-100 }\end{array}$ & $5 E-3$ & $8.5 E-3$ & $1.1 E-2$ \\
\hline IE-95(pH 10.4) & & & \\
\hline Column volume & $2.2 E+1$ & $3.1 E+1$ & $3.5 E+1$ \\
\hline $\begin{array}{l}\text { Moles Cs loaded } \\
\text { per } L \text { of IE-95 }\end{array}$ & $2.2 E-2$ & $3.1 E-2$ & $3.5 E-2$ \\
\hline $1 / T^{\circ} \mathrm{K}$ & $3.10 \mathrm{E}-3$ & $3.36 E-3$ & $3.58 E-3$ \\
\hline $\begin{array}{l}\text { IE- } 95 / \text { CS-100 } \\
\text { Cs capacity rat }\end{array}$ & $2.6 E+0$ & $3.6 E+0$ & $3.2 E+0$ \\
\hline
\end{tabular}
(a) Conditions: $7 \mathrm{M} \mathrm{Na}^{+}, 1 \times 10^{-3} \underline{\mathrm{M}} \mathrm{Cs}^{+}$.
Breakthrough: $\mathrm{C} / \mathrm{CO}=0.5$.

TABLE 33. Cesium Loading Capacity on IE-95 and CS-100 as a Function of the $\mathrm{Na} / \mathrm{Cs}$ Mole Ratio for the West Valley Alkaline Supernatant

\begin{tabular}{|c|c|c|c|}
\hline & $\begin{array}{c}\mathrm{Na} / \mathrm{Cs} \\
\text { Mole Ratio } \\
\end{array}$ & $\begin{array}{l}\text { Column Volumes } \\
\text { at } 0.5 \mathrm{C} / \mathrm{Co} \\
\end{array}$ & $\begin{array}{l}\text { Moles Cs Loaded/ } \\
\mathrm{L} \text { of Exchanger }\end{array}$ \\
\hline \multirow[t]{3}{*}{ IE-95 (pH 10.4) } & $7.0 \mathrm{E}+3$ & 27.2 & $2.7 E-2$ \\
\hline & $1.6 E+4$ & 31.5 & $1.4 \mathrm{E}-2$ \\
\hline & $1.2 E+5$ & 34 & $2.0 E-3$ \\
\hline \multirow[t]{3}{*}{$\mathrm{CS}-100(\mathrm{pH} 13.6)$} & $7.2 E+3$ & 8.7 & $8.7 E-3$ \\
\hline & $7.2 E+4$ & 13.2 & $1.3 E-3$ \\
\hline & $7.2 E+5$ & 20.3 & $2.0 E-4$ \\
\hline
\end{tabular}




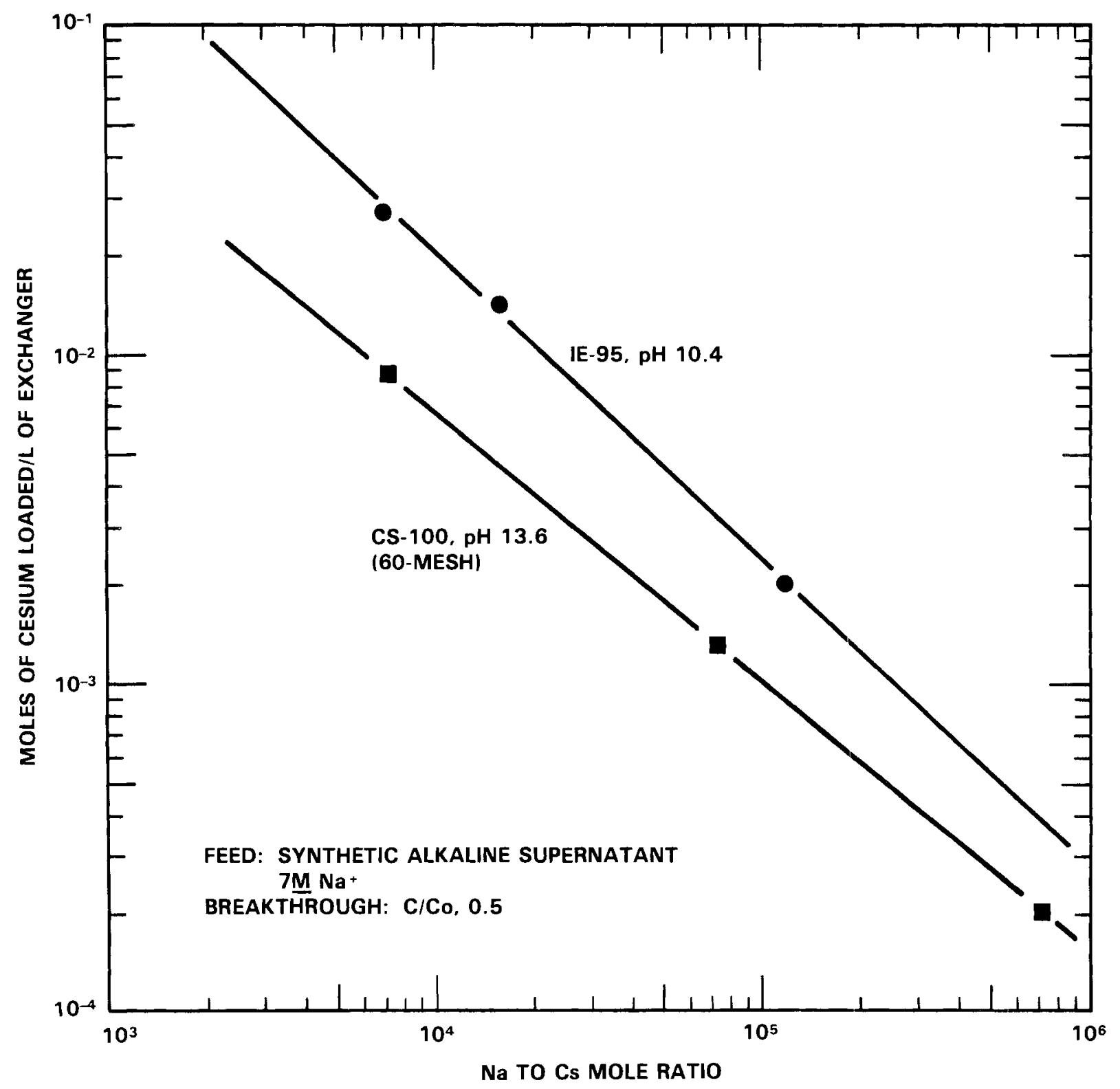

FIGURE 36. Cesium Loading Capacity as a Function of Na/Cs Mole Ratio 


\section{REFERENCES}

Barletta, R. E. and K. J. Swyler. 1983. Irradiation of Zeolite Ion-Exchange Media. NUREG/CR-2785(BNL-NUREG-51551), Brookhaven National Laboratory for U.S. Nuclear Regulatory Commission, Washington, D.C.

Baumgarten, P. K., M. A. Ebra, L. L. Kilpatrick, and L. M. Lee. 1980. Ion Exchange Processes for Decontaminating Alkaline Radioactive Wastes. $\overline{D P}-M S-$ 80-91, E. I. du Pont de Nemours \& Co., Inc. for Savannah River Laboratory, Aiken, South Carolina.

Beard, S. J. 1964. Technetium Recovery and storage at B-Plant, Hanford Project. HW-83348, General Electric Co., Richland, Washington.

Bray, L. A. and H. H. Van Tuyl. 1961. Recovery of Cesium from PUREX Tank Farm Supernatant Solution by Ferrocyanide Precipitation and Absorption on Decalso. HW-70674, General Electric Company, Richland, Washington.

Buckingham, J. S., ed. 1967. Waste Management Technical Manual. ISO-100-DEL, I sochem Inc., Richland, Washington.

Chandler, J. R. 1981. Revisions to the Stage 2 DWPF Bases for Development of Flowsheets and MateriaT Balances. DPST-81-326 revised, E. I. du Pont de Nemours \& Co., Inc. for Savannah River Laboratory, Aiken, South Carolina.

E. I. du Pont de Nemours \& Company, Inc. 1980. Waste Management Program Technical Progress Report, July-September 1980. DP-80-125-3, Aiken, South Carolina.

E. I. du Pont de Nemours \& Company, Inc. 1981. Technical Data Summary for Defense Waste Processing Facility. DPSTD-80-39-2, Aiken, South Carolina.

Gangwer, T. E., M. Goldstein, and K. K. Pillay. 1978. Radiation Effects on Ion Exchange Materials. BNL-50781, Brookhaven NationaT Laboratory, Upton, New York.

Grant, D. C. 1983. West Valley Supernatant Treatment Studies Using Ion Exchange. 83-8E4-EASTV-R1, Westinghouse R\&D Center, Pittsburgh, Pennsylvania.

Hitz, C. G., et al. 1982. "TMI-2 Containment Sump Water Cleanup Using the Submerged Demineralizer System." Presented at the American Institute of Chemical Engineers' Annual Meeting, November 14-16, 1982, Los Angeles, California.

Lee, L. M. and L. L. Kilpatrick. 1982. A Precipitation Process for Supernatant Decontamination. DP-1636, E. I. du Pont de Nemours \& Company, Inc. for Savannah River Laboratory, Aiken, South Carolina. 
Nelson, J. L. and B. W. Mercer. 1963. Ion-Exchange Separation of Cesium from Alkaline Waste Supernatant Solutions. HW-76449, General Electric Co., Richland, Washington.

Roberts, F. P., F. M. Smith and E. J. Wheelwright. 1963. Recovery of Technetium-99 from Hanford Wastes. HW-73121, General Electric Co., Richland, Washington.

Swift, W. H. 1962. Fission Product and Waste Packaging by Inorganic Zeolite Absorption. HW-73964, General Electric Co., Richland, Washington.

U.S. Department of Energy. 1978. Western New York Nuclear Service Center Companion Report. TID-28905, U.S. Department of Energy, Washington, D.C.

U.S. Department of Energy. 1982. Long-Term Management of Liquid High-Level Radioactive Wastes Stored at the Western New York Nuclear Service Center, West Valley. DOE/EIS-0081, Washington, D.C.

Wallace, R. M. and J. R. Wiley. 1975. Removal of Cesium from Savannah River Plant Waste Supernate. DP-1388, E. I. du Pont de Nemours \& Company, Inc. for Savannah River Laboratory, Aiken, South Carolina.

Wallace, R. M. and R. B. Ferguson. 1980. Development of an Improved Ion Exchange Process for Removing Cesium and Strontium from High-Level Radioactive Liquid Wastes. DP-MS-80-65 Rev., E. I. du Pont de Nemours \& Company, Inc. for Savannah River Laboratory, Aiken, South Carolina.

Wiley, J. R. 1976a. Decontamination of Savannah River Plant Waste Supernate. DP-1436, E. I. du Pont de Nemours \& Company, Inc. for Savannah River Laboratory, Aiken, South Carolina.

Wiley, J. R. 1976b. A Study of Methods for Removing Strontium, Plutonium, and Ruthenium from Savannah River Plant Waste Supernate. DP-1408, E. I. du Pont de Nemours \& Company, Inc. for Savannah River Laboratory, Aiken, South Carolina. 
APPENDIX A

PREPARATION OF WEST VALLEY SIMULATED ALKALINE WASTE 

APPENDIX A

PREPARATION OF WEST VALLEY SIMULATED ALKALINE WASTE

Two approaches have been used to prepare the simulated West Valley alkaline waste. In earlier studies, the simulated wastes were prepared by neutralization of acidic PUREX wastes, resulting in formation of a sludge phase and a supernatant phase. Based upon this initial work, it was recommended that the precipitant chemicals be added to a separated supernatant phase only. Experimental work was then continued using an alkaline supernatant starting feed prepared by mixing the appropriate chemicals. Both experimental approaches are summarized below.

\section{PRECIPITATION APPROACH TO SUPERNATANT PREPARATION}

The procedure involves preparation of simulated acidic PUREX wastes with the addition of either ${ }^{137} \mathrm{Cs},{ }^{85} \mathrm{Sr},{ }^{237} \mathrm{~Np},{ }^{24} 1_{\mathrm{Am}},{ }^{99} \mathrm{Tc},{ }^{154} \mathrm{Eu}$, or ${ }^{238} \mathrm{Pu}$. The acidic waste is neutralized and the $\mathrm{pH}$ adjusted to 10 or 12.8 with excess sodium hydroxide $(\mathrm{NaOH})$. The solution is then thermally digested for 24 hours. Upon neutralization, a solid phase forms and settles to the bottom of the test beaker. The supernatant is clarified by centrifugation, and the amount of Cs, $\mathrm{Sr}, \mathrm{Np}, \mathrm{Am}, \mathrm{TC}, \mathrm{Eu}$, or $\mathrm{Pu}$ remaining in solution is then determined by beta or gamma analysis. The sludge and supernatant contain the following:

\begin{tabular}{cc} 
Component & Concentration, M \\
\cline { 1 - 2 } $\mathrm{Na}$ & $\sim 7 \mathrm{E}+0$ \\
$\mathrm{~K}$ & $1.6 \mathrm{E}-1$ \\
$\mathrm{Rb}$ & $1.1 \mathrm{E}-4$ \\
$\mathrm{Cs}$ & $1.1 \mathrm{E}-3$ \\
$\mathrm{Sr}$ & $2.7 \mathrm{E}-5$ \\
$\mathrm{Ba}$ & $3.0 \mathrm{E}-4$ \\
$\mathrm{Mn}$ & $1.3 \mathrm{E}-2$ \\
$\mathrm{Mo}$ & $6.0 \mathrm{E}-3$ \\
$\mathrm{Fe}$ & $3.3 \mathrm{E}-1$
\end{tabular}

\begin{tabular}{|c|c|}
\hline Component & Concentration, $\underline{M}$ \\
\hline Al & $1.5 \mathrm{E}-2$ \\
\hline $\mathrm{Zr}$ & $3.4 E-4$ \\
\hline Sm & $4.4 E-3$ \\
\hline $\mathrm{NO}_{3}$ & 4.4E+0 \\
\hline $\mathrm{NO}_{2}$ & $1.8 E+0$ \\
\hline $\mathrm{OH}$ (Free) & $0-2.5 \quad E-1$ \\
\hline $\mathrm{SO}_{4}$ & $3.2 \mathrm{E}-1$ \\
\hline $\mathrm{PO}_{4}$ & $1.0 \mathrm{E}-1$ \\
\hline $\mathrm{Cl}$ & $4.3 E-3$ \\
\hline
\end{tabular}




\begin{tabular}{|c|c|c|c|}
\hline Component & Concentration, $M$ & Component & Concentration, $M$ \\
\hline $\mathrm{Cr}$ & $2.9 E-2$ & $\mathrm{CO}_{3}$ & $3.9 \mathrm{E}-1$ \\
\hline $\mathrm{Ni}$ & $1.3 \mathrm{E}-2$ & $\mathrm{~F}$ & $2.7 \mathrm{E}-2$ \\
\hline
\end{tabular}

One-liter batches of spiked alkaline waste are prepared by the following procedure.

$600 \mathrm{~mL}$ of Stock $A$, a solution containing mostly metal nitrates and $\mathrm{NaNO}_{3}$, is spiked with the radionuclide of interest. To this spiked solution, $17.8 \mathrm{~mL}$ of concentrated $\mathrm{H}_{2} \mathrm{SO}_{4}$ and $6.8 \mathrm{~mL}$ of concentrated $\mathrm{H}_{3} \mathrm{PO}_{4}$ are added. The $\mathrm{pH}$ of the solution is then adjusted by addition of either $100 \mathrm{~mL}$ of Stock $\mathrm{B}$, an $\mathrm{NaOH}$ solution (for $\mathrm{pH} \sim 10$ waste), or $126 \mathrm{~mL}$ of Stock $B$ (for $\mathrm{pH} 13$ waste). Finally, $352 \mathrm{~mL}$ of Stock $\mathrm{C}$, containing $\mathrm{NaNO}_{2}$ and $\mathrm{Na}_{2} \mathrm{CO}_{3}$, is added to the simulated waste and the mixture digested at 90 to $95^{\circ} \mathrm{C}$ for 24 hours, and then cooled.

\section{COMPOSITION OF STOCK SOLUTIONS}

Stock solutions $A, B$, and $C$ were composed of the components listed below with their concentrations in moles.

Stock Solution A

\begin{tabular}{lc}
\hline \multicolumn{1}{c}{ Component } & Concentration, $M$ \\
\cline { 1 - 2 } $\mathrm{NaCl}$ & $7.2 \mathrm{E}-3$ \\
$\mathrm{NaNO}_{3}$ & $5.4 \mathrm{E}+0$ \\
$\mathrm{Al}\left(\mathrm{NO}_{3}\right)_{3} \cdot 9 \mathrm{H}_{2} \mathrm{O}$ & $2.4 \mathrm{E}-2$ \\
$\mathrm{Ni}\left(\mathrm{NO}_{3}\right)_{2} \cdot 6 \mathrm{H}_{2} \mathrm{O}$ & $2.2 \mathrm{E}-2$ \\
$\mathrm{Cr}\left(\mathrm{NO}_{3}\right)_{3} \cdot 9 \mathrm{H}_{2} \mathrm{O}$ & $4.8 \mathrm{E}-2$ \\
$\mathrm{KNO}$ & $2.1 \mathrm{E}-1$ \\
$\mathrm{Fe}\left(\mathrm{NO}_{3}\right)_{3} \cdot 9 \mathrm{H}_{2} \mathrm{O}$ & $5.5 \mathrm{E}-1$ \\
$\mathrm{CsNO}$ & $1.8 \mathrm{E}-3$ \\
$\mathrm{Sr}\left(\mathrm{NO}_{3}\right)_{2}$ & $4.6 \mathrm{E}-5$ \\
$\mathrm{RbNO}$ & $1.8 \mathrm{E}-4$ \\
$\mathrm{Ba}\left(\mathrm{NO}_{3}\right)_{2}$ & $5.0 \mathrm{E}-4$
\end{tabular}

Stock Solution B

$\begin{array}{ll}\frac{\text { Component }}{\mathrm{NaOH}} & \frac{\text { Concentration, } \mathrm{M}}{1.9 \mathrm{E}+1} \\ \mathrm{MoO}_{3} & 9.8 \mathrm{E}-2\end{array}$

\begin{tabular}{lr} 
Stock Solution C \\
\hline $\mathrm{NaNO}_{2}$ & $5.0 \mathrm{E}+0$ \\
$\mathrm{Na}_{2} \mathrm{CO}_{3}$ & $1.1 \mathrm{E}+0$
\end{tabular}


Stock Solution A

\begin{tabular}{|c|c|}
\hline Component & Concentration, $\mathrm{M}$ \\
\hline $\mathrm{Zr}\left(\mathrm{NO}_{3}\right)_{4} \cdot 5 \mathrm{H}_{2} \mathrm{O}$ & $5.7 \mathrm{E}-4$ \\
\hline $\mathrm{Sm}\left(\mathrm{NO}_{3}\right)_{3}$ & $7.3 \mathrm{E}-3$ \\
\hline $\mathrm{Mn}\left(\mathrm{NO}_{3}\right)_{2}$ & $2.2 \mathrm{E}-2$ \\
\hline$H F$ & $4.5 \mathrm{E}-2$ \\
\hline $\begin{array}{l}\text { specific gravity, } \\
\mathrm{g} / \mathrm{mL}\end{array}$ & $1.4 E+0$ \\
\hline
\end{tabular}

CHEMICAL MIXING APPROACH TO SUPERNATANT PREPARATION

This procedure for preparation of alkaline supernatant containing ${ }^{238} \mathrm{Pu}$, ${ }^{85} \mathrm{Sr}$, or ${ }^{137} \mathrm{Cs}$ involves direct mixing of the appropriate chemicals. The following table summarizes the chemicals used to prepare the simulated supernatant and the element concentrations as determined by chemical makeup.

West Valley Synthetic Supernatant Prepared by Chemical Mixing

\begin{tabular}{|c|c|c|c|}
\hline \multicolumn{4}{|c|}{ Chemical Makeup (a) } \\
\hline Component & Concentration, $\mathrm{g} / \mathrm{L}$ & Element & Concentration, $\mathrm{M}$ \\
\hline $\mathrm{NaNO}_{3}$ & $2.9 E+2$ & $\mathrm{Na}$ & $\sim 7.0 \mathrm{E}+0$ \\
\hline $\mathrm{Na}_{2} \mathrm{SO}_{4}$ & $3.6 E+1$ & K & $1.6 \mathrm{E}-1$ \\
\hline $\mathrm{KNO}_{3}$ & $1.6 E+1$ & Cs & $1.0 \mathrm{E}-3$ \\
\hline $\mathrm{Cr}\left(\mathrm{NO}_{3}\right)_{3} \cdot 9 \mathrm{H}_{2} \mathrm{O}$ & $2.6 E-2$ & $\mathrm{Rb}$ & $1.0 E-4$ \\
\hline $\mathrm{Fe}\left(\mathrm{NO}_{3}\right)_{3} \cdot 9 \mathrm{H}_{2} \mathrm{O}$ & $1.2 \mathrm{E}-2$ & $\mathrm{Cr}$ & $2.0 E-3$ \\
\hline $\mathrm{NaCl}$ & $2.3 E+0$ & $\mathrm{Fe}$ & $3.0 E-5$ \\
\hline $\mathrm{RbNO}_{3}$ & $5.9 E-2$ & $\mathrm{NO}_{3}$ & $3.4 E+0$ \\
\hline $\mathrm{CsNO}_{3}$ & $1.8 \mathrm{E}-1$ & $\mathrm{NO}_{2}$ & $2.2 E+0$ \\
\hline $\mathrm{Na}_{2} \mathrm{CO}_{3}$ & $4.1 E+1$ & $\mathrm{SO}_{4}$ & $2.5 E-1$ \\
\hline $\mathrm{NaNO}_{2}$ & $1.5 E+2$ & $\mathrm{Cl}$ & $4.0 \mathrm{E}-2$ \\
\hline $\mathrm{H}_{3} \mathrm{PO}_{4}, \mathrm{~mL}$ & 6.7 & $\mathrm{p}$ & $1.0 \mathrm{E}-2$ \\
\hline $\mathrm{NaOH}$ & $0(\mathrm{pH} \mathrm{10.4)}$ & $\mathrm{CO}_{3}$ & $3.9 E-1$ \\
\hline & $1.9 E+1(p H ~ 13.7)$ & $\mathrm{OH}$ & 0 to $2.2 \mathrm{E}-1$ \\
\hline & & $\mathrm{pH}$ & 10.4 to 13.7 \\
\hline
\end{tabular}

(a) After dissolution, the liter of solution is adjusted to weigh $1340 \mathrm{~g}$, and is filtered through prepleated, medium porosity filter paper to remove any foreign material. 
Strontium-85 and ${ }^{238} \mathrm{Pu}$ are added to the supernatant solutions together. Five milliliters of $\mathrm{Sr}$ stock solution $\left(0.19 \mathrm{M} \mathrm{Sr}\left[\mathrm{NO}_{3}\right]_{2}\right.$ stock solution spiked with ${ }^{85} \mathrm{Sr}$ ) is added to $1 \mathrm{~L}$ of simulated supernatant. Plutonium-238 is also added $\left(\sim 10^{-9} \mathrm{M}\right)$ to the supernatant solution in a similar manner. The concentration of $\mathrm{Sr}$ and $\mathrm{Pu}$ in the stock solutions added to the supernatant is greater than the quantity of each isotope which is soluble in the supernatant. Consequently, the majority of $\mathrm{Sr}$ and $\mathrm{Pu}$ was precipitated over a 48-hour digestion period. The resulting alkaline supernatant is filtered through $0.2 \mu \mathrm{m}$ filter paper prior to use in the experiments. Cesium-137 is added to samples of alkaline supernatant without additional filtering. Technetium-99 is added to obtain a concentration of $0.044 \mathrm{~g} / \mathrm{L}$ in the supernatant.

Concentrations of ${ }^{85} \mathrm{Sr},{ }^{137} \mathrm{Cs}$, and ${ }^{238} \mathrm{Pu}$ are determined by counting the stock solution. The solubility of the $\mathrm{Sr}$ in this feed is $\sim 10^{-5} \mathrm{M}$. The ${ }^{85} \mathrm{Sr}$ count rate in the prepared supernatant is lower than acceptable for use in the experiment. Therefore, additional ${ }^{85} \mathrm{Sr}$ is added to the supernatant to achieve acceptable counting statistics. The mass quanitity of ${ }^{85} \mathrm{Sr}$ added in this manner does not significantly increase the total concentration of Sr in the simulated supernatant. The concentration of ${ }^{238} \mathrm{Pu}$ is $\sim 10^{-11} \mathrm{M}$ in the supernatant; however, the Pu valence has not been determined.

RADIOTRACER ANALYSIS

Gamma counting is used for radiotracers of ${ }^{137} \mathrm{Cs},{ }^{22} \mathrm{Na},{ }^{152-154} \mathrm{Eu}$, and ${ }^{85} \mathrm{Sr}$. These tracers do not significantly increase the total concentration of the specific ion in the simulated supernatant but are used to follow the ions pathway. A $4 \mathrm{~mL}$ sample of the initial "spiked" feed is used as the standard. During the test program, $4 \mathrm{~mL}$ samples of waste effluent or eluate are compared with the standard. Gamma counting is performed by the use of a multichannel analyzer and a $\mathrm{NaI}$ well detector. 
Samples containing alpha or beta emitters such as I, Np, Am, and Tc are counted using a Tri-Carb 300-C scintillation counter after mixing $1 \mathrm{~mL}$ of standard or sample with $15 \mathrm{~mL}$ of xylene-surfactant-based scintillation cocktail such as PCS.

To analyze for $\mathrm{Pu}$, samples containing ${ }^{238} \mathrm{Pu}$ or mixtures of ${ }^{238} \mathrm{Pu}-{ }^{137} \mathrm{Cs}$ or ${ }^{238} \mathrm{Pu}-{ }^{85} \mathrm{Sr}$ require a $\mathrm{Pu}$ extraction prior to scintillation counting. Samples $(1 \mathrm{~mL})$ are mixed with $1 \mathrm{~mL}$ of $10 \mathrm{M} \mathrm{HNO}_{3}$ and heated to destroy nitrates. The sample is then mixed with $10 \mathrm{~mL}$ of $2 \mathrm{M} \mathrm{HNO}_{3}$ containing $0.1 \mathrm{~mL}$ of $200 \mathrm{~g} / \mathrm{L}$ urea. The resulting aqueous solution is contacted with $10 \mathrm{~mL}$ of $\mathrm{Pu}$ extractant/ scintillation cocktail. This organic mixture is prepared by mixing $0.0225 \mathrm{M}$ p-terphenyl, 0.22M HDEHP(a), and 0.0014M POPOP(b) in toluene. The organic and aqueous phases are allowed to separate after stirring for 15 minutes. Five $\mathrm{mL}$ of the organic phase containing the $\mathrm{Pu}$ is transferred into a second vial containing $10 \mathrm{~mL}$ of new $2 \mathrm{M} \mathrm{HNO}_{3}$. The sample is again stirred for 15 minutes to scrub traces of the aqueous phase ${ }^{137} \mathrm{Cs}$ or ${ }^{85} \mathrm{Sr}$ from the organic phase. The organic phase on top of the aqueous phase is then counted by liquid scintillation without further separation.

(a) HDEHP: di-(2-ethylhexyl)phosphoric acid. (b) POPOP: p-bis(2-[phenyloxazolyl])benzene. 


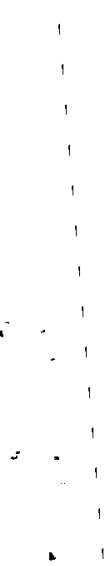


APPENDIX B

WASHING PROCEDURES FOR WEST VALLEY SIMULATED ALKALINE WASTE SLUDGE 

APPENDIX B

WASHING PROCEDURES FOR WEST VALLEY ALKALINE SIMULATED WASTE SLUDGE

The current process approach for treatment of the alkaline PUREX waste stored at West Valley involves separation of the sludge and supernatant, and washing of the resultant sludge to remove soluble salts. The objective of this work is to develop chemical and radiochemical data for the various chemical and radiochemical species distribution between the sludge and supernatant during the sludge-washing process. Two scenarios were investigated: 1) the case of the waste as it exists, and 2) the case in which $\mathrm{Na}-\mathrm{TiA}$ has been added to the waste to remove $\mathrm{Pu}$ and $\mathrm{Sr}$.

Simulated waste representing the West Valley HLW was prepared by the neutralization and precipitation of simulated acidic PUREX waste (see Appendix A). The simulated waste was spiked with ${ }^{85} \mathrm{Sr},{ }^{137} \mathrm{Cs},{ }^{99} \mathrm{Tc},{ }^{152-154} \mathrm{Eu}$, ${ }^{237} \mathrm{~Np},{ }^{241} \mathrm{Am}$, or ${ }^{238} \mathrm{Pu}$. The simulated sludge was washed to a sulfate concentration equivalent to 1 wt\% $\mathrm{Na}_{2} \mathrm{SO}_{4}$ in the waste glass. The chemical species of interest in the washing study are $\mathrm{NO}_{3}{ }^{-}, \mathrm{NO}_{2}{ }^{-}, \mathrm{SO}_{4}=$, and $\mathrm{Na}^{+}$. Wastes of $\mathrm{pH} \sim 10$ and $\mathrm{pH} \sim 13$ were prepared, and the effect of the additive $\mathrm{Na-TiA}$ was investigated. Radiochemical data were developed for the $\mathrm{pH} \sim 10$ case only.

\section{SLUDGE WASHING WITHOUT PRECIPITANTS}

The simulated waste was separated into sludge and supernatant phases with an International Equipment Co. centrifuge, Size 1, Type SB. In some instances it was not possible to decant off as much supernatant as desired because the simulated sludge was not as well settled as actual West Valley sludge. In these cases, as much supernatant was decanted as possible. Below is the general procedure used for $1 \mathrm{~L}$ batches.

The supernatant is decanted from the sludge and then $375 \mathrm{~mL}$ of distilled water is added to the sludge. The mixture is agitated for 24 hours and then centrifuged, and the $375 \mathrm{~mL}$ wash solution is 
decanted. The procedure is repeated three times, adding and decanting 230,200 , and $180 \mathrm{~mL}$ of supernatant for the second, third, and fourth wash steps, respectively. After the final decant step, the sludge is dissolved in $\mathrm{HCl}$ for analytical purposes and diluted to $5000 \mathrm{~mL}$. Samples are taken of the supernatiant and the wash solutions at each step, and of the final dissolved sludge. sludge samples containing tracers will be dissolved in $\mathrm{HNO}_{3}$.

\section{SLUDGE WASHING WITH Na-TiA}

The procedure used for the sludge washing with $\mathrm{Na}-\mathrm{TiA}^{\mathrm{A}}\left(\mathrm{Na}_{2} \mathrm{Ti}_{3} \mathrm{O}_{7}\right)$ is virtually the same as that for the sludge without additives. The simulated waste, however, is first contacted with $62 \mathrm{~g}$ of $\mathrm{Na}-\mathrm{TiA} / \mathrm{L}$ and agitated at $25^{\circ} \mathrm{C}$ for $24 \mathrm{~h}$. The addition of $62 \mathrm{~g}$ of $\mathrm{Na}-\mathrm{TiA} / \mathrm{L}$ was based on the assumption that the supernatant was $2.74 \times 10^{-8} \underline{\mathrm{M}} \mathrm{Sr}$, and that a Na-TiA to $\mathrm{Sr}$ mole ratio of $2.45 \times 10^{6}$ was required. It was assumed that there was $1.05 \times 10^{-3}$ moles $/ \mathrm{g}$ of Na-TiA of centrifuged slurry. The Na-TiA is not allowed to dry during use, but is weighed for each sample after being centrifuged to a wet paste.

After the Na-TiA is agitated with simulated waste, the mixture is centrifuged and the washing process is initiated as in the no-additive case.

\section{CALCULATION OF Na-TIA WET PASTE MOLARITY}

The Na-TiA slurry purchased from AFF Inc., Marietta, Georgia, contained 7.2\% Na-TiA; $67.4 \%$ isopropyl alcohol; $7.8 \%$ sodium salts of nitrate, nitrite aluminate, and sulfate; and $17.6 \% \mathrm{H}_{2} 0$. The slurry settled easily. A centrifuged sample of slurry had a specific gravity of $1.07 \mathrm{~g} / \mathrm{mL}$. A $1 \mathrm{~mL}$ centrifuged sample was dried at $110^{\circ} \mathrm{C}$ for 16 hours and its weight assumed to be that of $\mathrm{Na}_{2} \mathrm{Ti}_{3} \mathrm{O}_{7}$ (molecular weight $=301.7$ ) was $0.317 \mathrm{~g}$. From these factors it was calculated that there was:

$\frac{0.317 \mathrm{~g} \mathrm{Na}_{2} \mathrm{Ti}_{3} \mathrm{O}_{7} / \mathrm{g} \mathrm{wet} \mathrm{paste}}{301.7 \mathrm{~g} \mathrm{Na}_{2} \mathrm{Ti}_{3} \mathrm{O}_{7} / \mathrm{mole} \mathrm{Na}_{2} \mathrm{Ti}_{3} \mathrm{O}_{7}}=1.05 \times 10^{-3}$ mole $\mathrm{Na}_{2} \mathrm{Ti}_{3} \mathrm{O}_{7} / \mathrm{g}$ wet paste. 
This was the value we assumed in this study.

SAMPLE ANALYSES

Chemical analyses for cations are obtained by use of inductively coupled argon plasma spectrography (ICP) using a Jarrell-Ash Model 975 spectrometer. The anion results are obtained by ion chromatography (IC) using a Dionex Model14 ion chromatograph.

Radiochemical trace analyses of ${ }^{85} \mathrm{Sr},{ }^{152-154} \mathrm{Eu}$, and ${ }^{137} \mathrm{Cs}$ are obtained by counting samples with a Canberra Model 40 multichannel gamma analyzer, which has a 7.6-cm-dia well NaI crystal detector. The ${ }^{238} \mathrm{Pu}$ tracer solution is

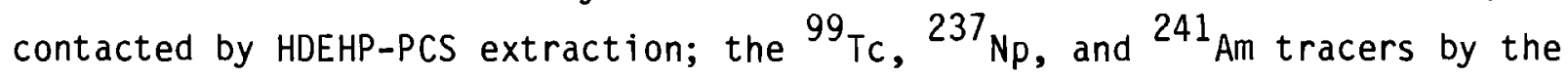
use of PCS; and both are counted by liquid scintillation. 


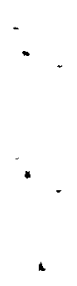




\section{APPENDIX C}

PROCEDURE TO TEST ADDITIVES THAT PRECIPITATE RADIONUCLIDES FROM ALKALINE SUPERNATANT 
APPENDIX C

PROCEDURE TO TEST ADDITIVES THAT PRECIPITATE

RADIONUCLIDES FROM ALKALINE SUPERNATANT

Laboratory-scale experiments were conducted to study the performance of a $\mathrm{Na}-\mathrm{TPB}$ precipitation process for recovery of $\mathrm{Cs}$ and a Na-TiA recovery process for $\mathrm{Sr}$ and $\mathrm{Pu}$ from simulated West Valley alkaline supernatant. The effect of the following process variables were examined: temperature $\left(25\right.$ and $\left.50^{\circ} \mathrm{C}\right), \mathrm{pH}$ (10.4 and 13.7), contact time ( 1 to 14 days), and quantity of precipitant chemical added.

The experimental procedure involved the use of simulated supernatants. The stock supernatant was spiked with ${ }^{137} \mathrm{Cs},{ }^{89} \mathrm{Sr}$, or ${ }^{238} \mathrm{Pu}$, and the solution filtered through $0.2 \mu \mathrm{m}$ filter paper. The precipitant chemicals added were either Na-TPB for Cs studies or Na-TiA for Sr and Pu studies. Sealed bottles of the test solutions were prepared and placed in a constant-temperature shaker oven maintained at $50^{\circ} \mathrm{C}$ or a room-temperature shaker table maintained at $25^{\circ} \mathrm{C}$. At defined time intervals, samples were withdrawn from the test bottles, poured through $0.2 \mu \mathrm{m}$ filter paper, and analyzed for the recovery fractions of ${ }^{137} \mathrm{Cs}$, ${ }^{85} \mathrm{Sr}$ (determined by gamma energy analysis), and ${ }^{238} \mathrm{Pu}$ (determined by extraction and scintillation counting).

\section{TEST PROCEDURE FOR Na-TiA}

Methods used to examine $\mathrm{Sr}$ and Pu recovery from simulated supernatants by the use of $\mathrm{Na}-\mathrm{TiA}\left(\mathrm{Na}_{2} \mathrm{Ti}_{3} \mathrm{O}_{7}\right)$ are described below.

Initially, a slurry of the alcohol- $\mathrm{H}_{2} \mathrm{O}-\mathrm{Na}_{2} \mathrm{Ti}_{3} \mathrm{O}_{7}$ precipitate is added to weighed sample bottles. The alcohol-water is separated from the $\mathrm{Na}_{2} \mathrm{Ti}_{3} \mathrm{O}_{7}$ by centrifugation and decantation, and the bottles reweighed. The Na-TiA paste should vary from 0.4 to $4.0 \mathrm{~g}$. To each sample bottle $50 \mathrm{~mL}$ of simulated supernatant ( $\mathrm{pH} 10.4$ to 13.7) is added. The resultant solutions are capped and placed in a 
constant-temperature $\left(50^{\circ} \mathrm{C}\right)$ oven, or directly on the shaker table $\left(25^{\circ} \mathrm{C}\right)$ and agitated. After agitation for a predetermined time period (from 1 to 14 days), a test bottle is removed, and a 5-mL sample is taken. The sample is filtered through a Gelman \#4192 Acrodisc filter disc (pore size $0.2 \mu \mathrm{m}$ ). About $4 \mathrm{~mL}$ of the resultant filtrate is sampled and counted for ${ }^{85} \mathrm{Sr}$ using gamma energy analysis to determine the Sr remaining in solution. The $4 \mathrm{~mL}$ sample is then returned to the test bottle, which is returned to the shaker table. The remaining $1 \mathrm{~mL}$ sample is extracted with $10 \mathrm{~mL}$ of organic HDEHP-PCS to recover the Pu. The extraction procedure does not remove traces of ${ }^{85} \mathrm{Sr}$ associated with the aqueous phase. However, the organic is scrubbed with $10 \mathrm{~mL}$ of $2 \mathrm{M} \mathrm{HNO}_{3}$ to remove traces of the aqueous phase containing ${ }^{85} \mathrm{Sr}$. Organic samples of $5 \mathrm{~mL}$ each that contain Pu are analyzed using liquid scintillation counting. The $1 \mathrm{~mL}$ sample used for $\mathrm{Pu}$ analysis is not returned to the bottle. Samples of the original stock supernatant serving as standards are filtered and counted as above.

The Na-TiA slurry purchased from AFF Inc. contained $7.2 \% \mathrm{Na}-\mathrm{TiA} ; 67.4 \%$ isopropyl alcohol; $7.8 \%$ sodium salts of nitrate, nitrite, aluminate, and sulfate; and $17.6 \% \mathrm{H}_{2} \mathrm{O}$. This slurry settled easily. A centrifuged sample of slurry should be analyzed for specific gravity. The centrifuged sample is dried at $110^{\circ} \mathrm{C}$ for 16 hours and its weight assumed to be that of $\mathrm{Na}_{2} \mathrm{Ti}_{3} \mathrm{O}_{7} / \mathrm{g}$ (molecular weight $=301.7$ ). From these factors, a value for the moles of $\mathrm{Na}_{2} \mathrm{Ti}_{3} \mathrm{O}_{7}$ per gram of centrifuged slurry is assumed. The Na-TiA slurry should not be allowed to dry out during use, but should be weighed out for each sample after being centrifuged in the test bottle.

\section{TEST PROCEDURE FOR Na-TPB}

Methods used to examine Cs precipitation using a sodium tetraphenylboron are described below.

Stock supernatant solutions of $25 \mathrm{~mL}$ each spiked with ${ }^{137} \mathrm{Cs}$ are blended with $0.4 \mathrm{M} \mathrm{Na}-\mathrm{TPB}$. The final alkaline supernatant $\mathrm{Na}^{+}$ion 
concentration (not including the $\mathrm{Na}^{+}$ion concentration with the $\mathrm{Na}-$ TPB) is held at a constant $\mathrm{Na}^{+}$ion concentration by adjusting the final volume with $\mathrm{H}_{2} \mathrm{O}$. To determine the effect of varying the $\mathrm{Na}^{+}$ ion concentration on the precipitation of $\mathrm{Cs}^{+}, 25 \mathrm{~mL}$ of supernatant was placed in shaker bottles with $1.5 \mathrm{~g}$ of solid $\mathrm{Na}-\mathrm{TPB}$. The $\mathrm{Na}^{+}$ ion concentration in the final solution of this series of tests varies from 3 to $6 \mathrm{M} \mathrm{Na}^{+}$by the addition of 4 to $34 \mathrm{~mL}$ of $\mathrm{H}_{2} \mathrm{O}$. The resultant solutions/precipitates are placed in test bottles, capped, and placed in a constant-temperature oven $\left(50^{\circ} \mathrm{C}\right)$, or placed directly on the shaker table $\left(25^{\circ} \mathrm{C}\right)$ and agitated. After agitation for a predetermined time period, a test bottle is removed, and a $5 \mathrm{~mL}$ sample is taken and filtered through a Gelman \#4192 Acrodisc filter disc (pore size of $0.2 \mu \mathrm{m})$. The resultant filtrate is sampled ( $4 \mathrm{~mL}$ ) and counted using gamma energy analysis to determine the $\mathrm{Cs}$ concentration remaining in solution. The $5 \mathrm{~mL}$ sample is then placed back in the test bottle and the bottle returned to the shaker table. Samples of the original stock supernatant are filtered and counted as above for the standards.

Stock solutions of $\mathrm{Na}-\mathrm{TPB}\left(\mathrm{Na}_{\mathrm{C}}\left[\mathrm{C}_{6} \mathrm{H}_{5}\right]_{4} \mathrm{~B}\right)$ were prepared. The $\mathrm{Na}-\mathrm{TPB}$ was purchased from AFF Inc. with 95\% purity. A formula weight of $360.2 \mathrm{~g}$ was used in preparation.

The following test parameters were examined for the Cs precipitation process:

- mole ratio $\mathrm{Na}-\mathrm{TPB} / \mathrm{Cs}+\mathrm{K}+\mathrm{Rb}(0.007$ to 2.3$)$

- $\mathrm{pH}$ (10 and 12)

- contact time (1 to 14 days)

- temperature $\left(25\right.$ and $\left.50^{\circ} \mathrm{C}\right)$

- Na concentration in the alkaline supernatant (3 to 6M). 


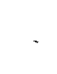




\section{APPENDIX D}

PROCEDURE TO MEASURE BATCH SORPTION RATIOS FOR ION-EXCHANGE MATERIALS USING RADIONUCLIDE TRACER TECHNIQUES 
$\because$

$\because:$

.

$\because$
$\because$ 
APPENDIX D

PROCEDURE TO MEASURE BATCH SORPTION RATIOS FOR ION-EXCHANGE MATER IALS USING RADIONUCLIDE TRACER TECHNIQUES

This procedure describes a method to determine the relative distribution ratio for the batch ion-exchange method for specific radionuclides. The laboratory batch methodology provides a rapid and cost-effective method of comparing a wide variety of ion-exchange materials for their selectivity of specific radionuclides. Batch ion-exchange experiments involve contacting a sample of supernatant that contains the radionuclide under investigation with a small, weighed sample of ion-exchange material. After steady state is approached, the distribution ratio $R_{d}$ is determined:

$$
R_{d}=\frac{C_{s}}{C_{1}}, \mathrm{~cm}^{3} / \mathrm{g}
$$

where

$$
\begin{aligned}
c_{s}= & \text { the concentration of radionuclide exchanged in or on the solid } \\
& \text { phase ( } \mathrm{g} / \mathrm{g} \text { of solid) } \\
C_{1}= & \text { the concentration of radionuclide remaining in the liquid phase } \\
& \left(\mathrm{g} / \mathrm{cm}^{3}\right. \text { of solution). }
\end{aligned}
$$

The $R_{d}$ generated by these batch selectivity experiments is a measure of the overall ability of the solid phase to remove the radionuclide from solution. The data are reported as distribution ratios $\left(R_{d}\right)$ rather than distribution coefficients $\left(K_{d}\right)$ because more than one mechanism may be involved and reversibility has not been demonstrated. In addition, contact temperature, contact time, and $\mathrm{pH}$ contribute to the value obtained.

\section{RADIOTRACERS}

Radiotracers used in this experiment include ${ }^{137} \mathrm{Cs},{ }^{99} \mathrm{Tc},{ }^{131} \mathrm{I},{ }^{85} \mathrm{Sr}$, ${ }^{237} \mathrm{~Np},{ }^{238} \mathrm{Pu}$, and ${ }^{241} \mathrm{Am}$. These radiotracers may be obtained either through commercial companies (e.g., New England Nuclear, Boston Massachusetts; or 
Amersham, Arlington, Illinois), or from stock solutions already available. Technical data sheets accompanying the commercial shipments list the assay of the isotope (i.e., chemical form, purity, assay date, specific activity, concentration, and volume). This data, combined with calibrated known radiostandards, is used to determine the final concentration of the radiotracer as it is added to the supernatant.

Special precautions are taken when adding the actinides to synthetic supernatant to ensure that the tracer is in solution and not precipitated. A known aliquot of radiotracer is added to the supernatant solution and equilibrated. The stock solution is then filtered prior to use in batch tests.

\section{COUNTING EQUIPMENT}

Gamma counting is performed by a multichannel analyzer and suitable detector; TC, I, Np, Pu, and Am are counted by mixing $1 \mathrm{~mL}$ of sample with $15 \mathrm{~mL}$ of scintillation cocktail such as PCS and counting the sample using a liquid scintillation system.

PREPARATION OF CANDIDATE ION-EXCHANGE RESIN

A sample $(0.1 \mathrm{~g})$ of material is weighed out on a 4- or 5-place analytical balance for each test. A $1 \mathrm{~g}$ sample of similar material is dried at $105 \pm 10^{\circ} \mathrm{C}$ for 24 hours and cooled in a desiccator before being reweighed to determine the correction factor $(F) .(a)$ One or two samples are weighed for each test and $\mathrm{placed}$ in $25 \mathrm{~mL}$ polyethylene bottles. Five to $20 \mathrm{~mL}$ of radionuclide spiked supernatant is added to each bottle. The bottle is sealed with a piece of Parafilm M (American Can Company, Greenwich, Connecticut) and then tightly capped and placed on an Eberbach mechanical shaker for continuous agitation. The agitation rate is set at $\sim 1$ stroke/ min.

\section{STANDARD SOLUTION}

A standard solution is prepared and placed in a similar $25 \mathrm{~mL}$ polyethylene bottle and treated as a normal sample. Each standard contains 5 to $20 \mathrm{~mL}$ of

(a) $F=\frac{\text { Weight }}{\text { of Material After Drying }\left(105^{\circ} \mathrm{C} \text { for } 24 \mathrm{~h}\right.}$ 
radionuclide-spiked supernatant. The sample is agitated, sampled, filtered, and counted with the other samples. The standard represents the supernatant prior to contact with the solid sample.

\section{FILTERING AND ANALYSIS PROCEDURE}

The samples and standard are removed from the shaker and allowed to settle for 24 hours. Approximately $5 \mathrm{~mL}$ of each sample is filtered using a Gelman $4192,0.2-\mu \mathrm{m}$ pore size disposable filter. After filtration, 3 to $4 \mathrm{~mL}$ of solution is transferred to standard gamma-counting tubes, or a $1-\mathrm{mL}$ sample is added to $15 \mathrm{~mL}$ of scintillation solution and stirred. The samples are gamma counted for 2 to 20 minutes, depending on the count rate, and the liquid scintillation samples are counted for 200 minutes or until the sample has reached the $2 \sigma$ confidence level.

REPORTING METHOD

$$
\begin{gathered}
R_{d}=\frac{\text { Filtered standard }(\mathrm{c} / \mathrm{m} / \mathrm{mL})-\text { Filtered sample }(\mathrm{c} / \mathrm{m} / \mathrm{mL})}{\text { Filtered Sample }(\mathrm{c} / \mathrm{m} / \mathrm{mL})} \times \\
\frac{\text { Sample volume }\left(\mathrm{cm}^{3}\right)}{\text { Weight of material }(\mathrm{g}) \times \mathrm{F}}=\mathrm{cm}^{3} / \mathrm{g}
\end{gathered}
$$

pH DETERMINATION

Each sample used for gamma counting is saved for $\mathrm{pH}$ determination. Since the liquid scintillation sample is a mixture of organic and aqueous material, it is not used for $\mathrm{pH}$ determination. Instead, the $2 \mathrm{~mL}$ of sample not required for analysis is removed from the centrifuge cone and placed in a bottle for later $\mathrm{pH}$ determination. The $\mathrm{pH}$ is determined for each sample using an Orion Research Microprocessor, Ionalyzer/901, and a Corning Combination electrode. The $\mathrm{pH}$ meter is standardized before and during the analysis of a number of samples using standard Beckman buffers covering the range of 7 to 10 . 

$\cdot$
$\therefore$

$י$

$:$
$\because:$

$\therefore$

$\therefore$

•. 


\section{DISTRIBUTION}

No. of

Copies

OFFSITE

27 DOE Technical Information Center

16 Nuclear Fuels Services, Inc. P.0. Box 191

West Valley, NY 14171

ATTN: D. E. Carl (5)

C. C. Chapman

J. C. Cwynar

W. H. Hannum (DOE)

W. R. Jacoby

J. L. Knabenschuh

J. E. Krauss

J. M. Pope (5)

ONSITE

7 DOE Richland Operations office

0. J. Elgert

R. D. Izatt

H. E. Ransom

J. J. Schreiber (2)

M. W. Shupe (2)

100 Pacific Northwest Laboratory

W. F. Bonner

W. J. Bjorklund

R. A. Brouns

J. L. Buelt

L. L. Burger

H. C. Burkholder

L. A. Bray (30)

J. R. Carrell (2)
No. of

Copies
L. A. Chick

T. D. Chikalla

R. L. Dillon

W. A. Glass

C. R. Hann

L. K. Holton (20)

J. H. Jarrett

S. E. King

D. E. Knowlton

L. T. Lakey

J. M. Latkovich

R. C. Liikala

R. P. Marshall/W. R. Wiley/ D. B. Cearlock

J. L. MCEl roy

G. B. Mellinger

T. R. Myers

J. E. Minor

D. E. Olesen

J. M. Perez, Jr.

A. M. Platt

R. C. Pratt

G. M. Richardson

J. M. Rusin

W. A. Ross

D. H. Siemens

W. G. Simanton

J. L. Swanson

G. L. Tingey/G. A. Jensen

R. P. Turcotte

H. H. Van Tuyl

E. J. Wheelwright

B. M. Wise (4)

Technical Information (5)

Publishing Coordination vg 
$\therefore$
$=$
$:$
$\therefore$ 